\title{
PRECOCIOUS SEXUAL DIMORPHISM AND THE LILLIPUT EFFECT IN NEO-TETHYAN OSTRACODA (CRUSTACEA) THROUGH THE PERMIAN-TRIASSIC BOUNDARY
}

\author{
MARIE-BEATRICE FOREL ${ }^{1}$, SYLVIE CRASQUIN ${ }^{2}$, ANISONG CHITNARIN ${ }^{3}$, LUCIA \\ ANGIOLINI $^{4}$ and MAURIZIO GAETANI ${ }^{4}$ \\ ${ }^{1}$ State Key Laboratory of Biogeology and Environmental Geology, China University of Geosciences, Wuhan, 430074, China; e-mail: mbforel@ yahoo.fr \\ ${ }^{2}$ CR2P CNRS - UPMC - MNHN, Sorbonne Universites, Paris 06, T.46-56, E.5, Case 104, 75252, Paris Cedex 05, France; e-mail: sylvie.crasquin@upmc.fr \\ ${ }^{3}$ School of Geotechnology, Institute of Engineering, Suranaree University of Technology, 111 University Avenue, Mueang District, Nakhon Ratchasima Province \\ 30000, Thailand; e-mail: anisong@sut.ac.th \\ ${ }^{4}$ Dipartimento di Scienze della Terra, Universita di Milano, Via Mangiagalli 34, 20133, Milano, Italy; e-mails: lucia.angiolini@unimi.it, maurizio.gaetani@unimi.it
}

Abstract: The Elikah River section spanning the Lopingian (Late Permian) to the Griesbachian (Early Triassic) time interval in the Central Alborz Mountains (north Iran) was sampled for ostracod analysis. We report 79 species distributed among 38 genera. Four new species are described: Acratia? pervagata Forel sp. nov., Microcheilinella alborzella Forel sp. nov., Basslerella superarella Crasquin sp. nov. and Cavellina nesenensis Crasquin sp. nov. The ontogeny of 13 species is described and sexual dimorphism in the genus Microcheilinella is here undoubtedly recognized for the first time. Six species show precocious sexual dimorphism of their carapace as early as A-5 juvenile. The Lilliput effect is for the first time recorded and quantified for two species. Rare long-time span Palaeocopida species, known throughout the entire Permian, document relatively long-term evolution, including the size and growth rate modifications associated with the earlier appearance of carapace sexual dimorphism through time. These patterns might be related to the Guadalupian-Lopingian events and/or to climatic modifications occurring during the Permian interval.

Key words: Ostracods, north Iran, Permian-Triassic, ontogeny, precocious sexual dimorphism, Lilliput effect. 


\section{INTRODUCTION}

The transition between the Permian and the Triassic (Permian-Triassic boundary, PTB) witnessed the most cataclysmic biotic crisis of the Phanerozoic, with extinction rates exceeding 90\% of the marine species (e.g. Sepkoski 1984; Erwin 1993; Payne and Clapham 2012 and references therein). The body size of organisms is a key parameter reflecting evolutionary and ecological factors. During a biotic crisis, size reduction is commonly observed in different fossil groups and has been termed 'the Lilliput effect' (Urbanek 1993). Many organisms show significant size reduction through the end-Permian extinction, including the brachiopods (Chen et al. 2005a, b; Twitchett 2005; He et al. 2007; Peng et al. 2007; Leighton and Schneider 2008), the gastropods (Fraiser and Bottjer 2004, 2007; Payne 2005), the bivalves (Hayami 1998), the ammonoids (Yang et al. 1993), the foraminifers (Jenny-Deshusses 1991; Song et al. 2011), the conodonts (Kozur 1996), the echinoderms (Twitchett and Oji 2005) and the fishes (Twitchett 2001; Mutter and Neuman 2009). Until recently, ostracods were believednot to be affected by the Lilliput effect through the endPermian events. However, abundant small specimens have been reported from the Lower Triassic microbialites of Turkey and attributed to the result of this effect (Forel 2014).

Ostracods are benthic microcrustaceans characterized by their bivalved calcified carapace enabling their long fossil record from the Ordovician to the Recent. As do all the other crustaceans, ostracods grow by successive moultings until they reach Adult stage. Each of these semaphoronts (i.e. every time slice of the life of organism; Hennig 1965) provides fundamental insights into the phylogenetic and evolutive history of these organisms, strongly related to environmental events (Høeg 1992; Maas et al. 2003; Haug et al. 2010).

Ostracods have been abundantly documented from the PTB transition worldwide, displaying extinction rates ranging from 68 to 100\% depending on the locality (see Crasquin and Forel 2014 for review). They abundantly survived in the localities where microbial matsdeveloped in the direct aftermath of the extinction (Hindeodus parvus - Isarcella isarcica conodont zones), locally providing dissolved oxygen and nutritive resource (Forel 2013; Forel et al. 2013a). In spite of these refuge conditions, the survivors are characterized by strong intraspecific variability possibly related to persistent deleterious conditions and heterochronies of the development by modified growth rates related to the changes of fecundity/reproduction required to maintain a viable population (Forel 2014). The PTB time interval is known from several localities in Iran displaying continuous marine successions, particularly the famous Julfa section (see synthesis in Gaetani et al. 2009; Leda et al. 2014; Schobben et al. 2014). The Elikah River section (N 36 $13^{\circ} 27^{\prime \prime}, \mathrm{E} 51^{\circ} 20^{\circ} 48^{\prime \prime}$ ) is located in the Central Alborz Mountains of northern Iran and was recently redescribed in detail by Gaetani et al. (2009) and Angiolini et al. (2010). This section was carefully sampled as part of a large-scale analysis of the extinction, the survival and the recovery patterns of the ostracods through the PTB, including South China (Meishan GSSP, Zhejiang Province: Crasquin et al. 2010a; Forel and Crasquin 2011a; Sichuan Province: CrasquinSoleau and Kershaw 2005; Guangxi Province: CrasquinSoleau et al. 2006a; Guizhou Province: Forel et al. 2009; Forel 2012; Tibet: Crasquin-Soleau et al. 2007, Forel and Crasquin 2011b; Forel et al. 2011), Turkey (Crasquin-Soleau et al. 2002, 2004a, b; Forel 2014), Hungary (Forel et al. 2013b), Italy (Crasquin et al. 2008), Saudi Arabia (Crasquin-Soleau et al. 2005, 2006b) and Serbia (Crasquin et al. 2010b). The ostracods of the PTB transition of Iran are known from the Zal section, north-west Iran (Kozur and Mette 2006; Mette 2008, 2010). The present study is the first to describe the ostracod faunas from the PTB in the Alborz Mountains, documenting important survival in the microbial mats following the end-Permian extinction in this area. It is furthermore the second record of such refuge conditions in the Neo-Tethys (Forel et al. 2013a; Forel 2014). 118 samples from the Lopingian (Late Permian; Nesen Formation) up to the Griesbachian (Early Triassic; Elikah Formation) in the Elikah River section were processed by hot acetolysis (Lethiers and CrasquinSoleau 1988; Crasquin-Soleau et al. 2005). About 6200 specimens were extracted from 58 productive samples, distributed among 79 species, belonging to 38 genera. Four new species are described: Acratia? pervagata Forel sp. nov., Microcheilinella alborzella Forel sp. nov., Basslerella superarella Crasquin sp. nov. and Cavellina nesenensis Crasquin sp. nov. The ontogenetic series of 13 species are newly described, 6 of which show the precocious sexual dimorphism of the carapace as early as A-5 juvenile stage. The analysis of Paraparchites chenshii and Cyathus caperata (Palaeocopida) spanning the entire Permian reveals a shift of the onset time of sexual dimorphism appearing earlier in the ontogeny of Upper Permian specimens compared to their Lower Permian counterparts, associated with size changes. These patterns are identified as the long-term heterochronies of the development (peramorphosis, predisplacement and deceleration) possibly related to global climatic conditions or GuadalupianLopingian events, which have been linked to a large flood basalt eruption, the Emeishan large igneous province (Zhou et al. 2002; Wignall et al. 2009; Bond et al. 2010). 


\section{GEOLOGICAL SETTING}

The Elikah River section is located in the Central Alborz Mountains in northern Iran, about 40 km north of Tehran (Fig. 1). The detailed description of the sedimentary succession from the Pennsylvanian to the Early Triassic in the Central and Eastern Alborz has been carried out by Gaetani et al. (2009). During the Pennsylvanian, a rift developed between Arabia and Central Iran (Al-Belushi et al. 1996; Jassim and Goff 2006), leading to the formation of the Neo-Tethys during the Early-Middle Permian (Garzanti 1999; Angiolini et al. 2003). During the Middle Permian, the Alborz was occupied by a large open-marine shelf, displaying common evolution with Cimmerian blocks, such as Transcaucasia and Taurids (Gaetani et al. 2009). During the Late Permian, southern areas stayed emerged due to low or inexistent subsidence, while the Alborz evolved as the northern passive margin of the Iranian microcontinent (Gaetani et al. 2009). During the Late Permian - Early Triassic interval, Iran was part of the Cimmerian terranes bathed by the Neo-Tethys (Fig. 1; Sengor 1979; Berberian and King 1981; Dercourt€et al. 1993; Crasquin-Soleau et al. 2001; Stampfli and Borel 2002). The northward migration of the Cimmerian blocks and the activation of the subduction of the Palaeo-Tethys oceanic crust along the Eurasian margin persisted during most of the PT time interval (Alavi 1991; Dercourt et al. 1993, 2000; Ruttner 1993; Besse et al. 1998; Stampfli and Borel 2002; Zanchi et al. 2009; see Sengor 1979, 1990 for€ alternative hypothesis). The studied area transited through the tropical arid belt during the Middle Permian and entered the humid equatorial zone during the Late Permian, leading to the deposition of the lower part of the Nesen Formation. The return of the microplate to an arid tropical latitude during the Early Triassic, associated with the continuation of this northward drift, corresponds to the deposition of the carbonate tidal flats of the Elikah Formation (Gaetani et al. 2009).

The Nesen Formation is about $130 \mathrm{~m}$ thick and consists of marly limestone and cherty limestone. It is divided into lower and upper members. The lower member ( $70 \mathrm{~m}$ thick) is made of dark grey shale interbedded with thin- to medium-bedded nodular marly limestone with scattered volcanic layers at the base. It contains

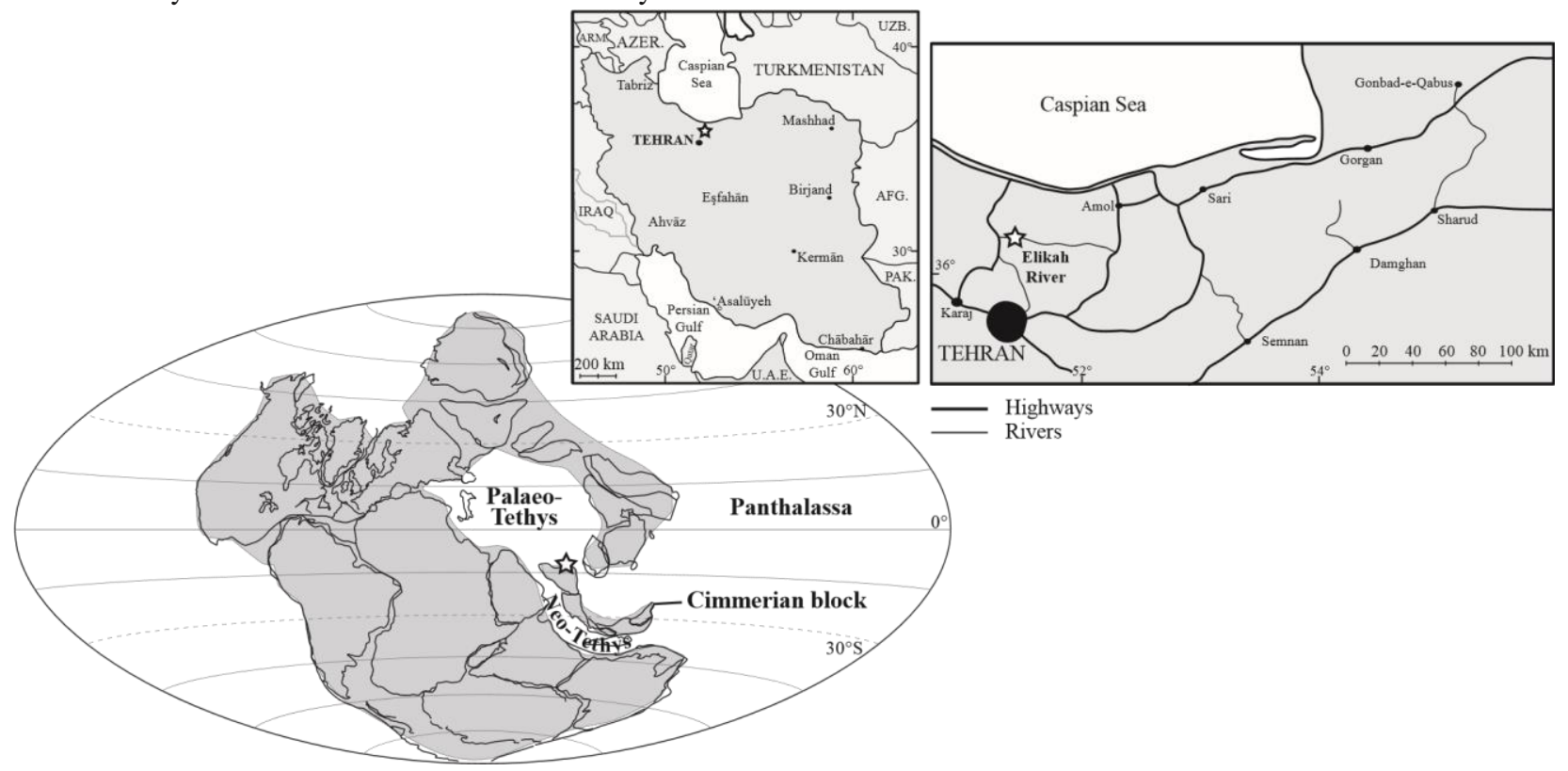

FIG. 1. Palaeogeographical map during the Middle Permian (modified from Crasquin-Soleau et al. 2001) showing the location of the Elikah River section, Alborz, north Iran.

abundant bioclasts, brachiopods, dasycladacean algae and foraminifera (e.g. Gaetani et al. 2009; Angiolini and Carabelli 2010; Angiolini et al. 2010 and references therein). Its first 10-15 m might be latest Capitanian in age (Angiolini et al. 2010), while the rest of the member is characterized by the Araxilevis intermedius biozone beginning in the early Wuchiapingian (Iranian-Chinese Research Group 1995). The upper member ( 60 m thick) records a decrease in shaly intercalations and an increase in micritic limestone. It is mostly composed of bioclastic limestone, marly limestone and marlstone. Abundant organisms have been reported, for example brachiopods and foraminifers (e.g. Gaetani et al. 2009; Angiolini and Carabelli 2010; Angiolini et al. 2010 and references therein). The occurrence of the conodont Hindeodus julfensis (Sweet) in sample 03IR157 indicates a late Wuchiapingian - early Changhsingian age (Fig. 2). While the foraminifer assemblage points to a Wuchiapingian- Changhsingian age. According to Angiolini and Carabelli (2010), the Nesen Formation shows an evolution 


\section{[Digitare qui]}

from depth below storm wave base in the lower member to shallower depth and higher energy close to the fairweather wave base in the upper member. The upper $34.7 \mathrm{~m}$ of the Nesen Formation has been sampled for the present investigation.

The Elikah Formation conformably overlies the Nesen Formation and comprises several lithological units, not all of which are visible in all the localities where the Elikah Formation crops out. At the very base, $40 \mathrm{~cm}$ of oolitic limestone yielded foraminifers and algae, overlain by $40 \mathrm{~cm}$ of nearly abiotic oolitic limestone. They are capped by domal and planar microbialites, microbial fabrics occurring in all samples from 03IR219 upwards (Pierre-Yves Collin, Burgundy University, pers. comm. 2011). Bivalves are locally abundant, dominated by Claraia and Eumorphotis (Gaetani et al. 2009 and references therein). The base of the Elikah Formation is still Changhsingian in age. The conodont Hindeodus parvus Kozur and Pjatakova, index for the base of the Triassic (Yin et al. 2001), occurs about $70 \mathrm{~cm}$ above the base of the Formation (IranianJapanese Research Group 1981). It co-occurs with the first occurrence of the foraminifer disaster taxon 'Cornuspira' mahajeri Bronnimann€ et al. (Angiolini et al. 2010). The conodont Isarcicella turgida Perri has been found in sample 03IR251, which still indicates an earliest Induan age. The Elikah Formation was deposited on a wide flat plain, submerged by a very shallow sea (Gaetani et al. 2009). The basal $15.6 \mathrm{~m}$ of the Elikah Formation has been sampled for ostracod study.

Based on facies, foraminifer and algal change, two large fourth-order cycles have been documented in the upper member of the Nesen Formation, continuing in the subsequent Elikah Formation (Angiolini et al. 2010). The lower cycle begins below sample 03IR163 and consists of mud-dominated facies. Its flooding surface is identified as the P40 of Sharland et al. (2001, 2004). The upper cycle starts around 03IR173 and consists of grainy facies, bioclastic packstone, oolitic packstone/grainstone and microbialites. The shift to grainy/oolitic facies around samples 03IR214-215 corresponds to the base of a thirdorder sequence, related to KS2 of Insalaco et al. (2006). The PTB is therefore part of a transgressive tract of this sequence. 


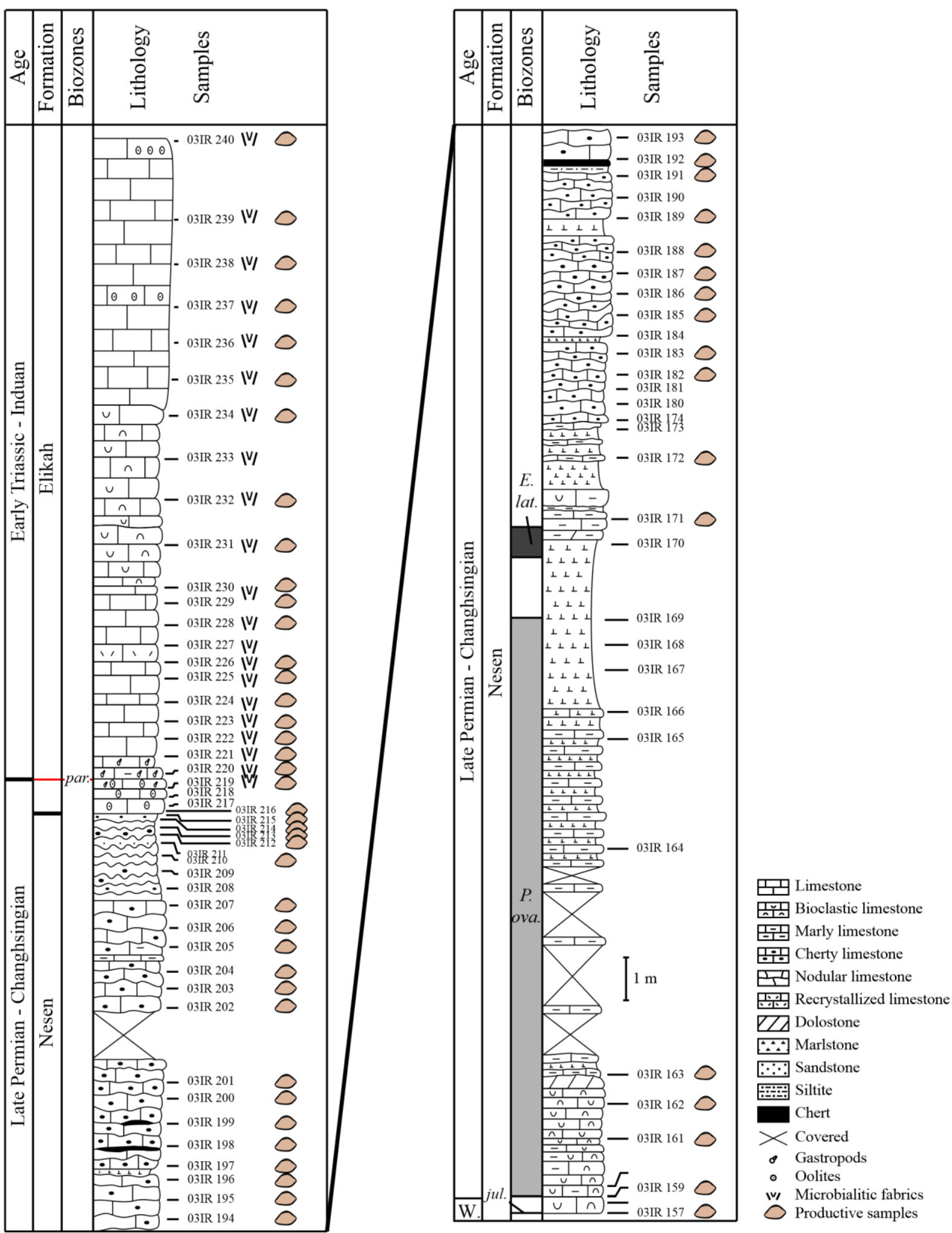

FIG. 2. Stratigraphical log, showing sample positions through the productive portion of the Elikah River section, Alborz, Iran. The reader is referred to Gaetani et al. (2009) for the complete succession and to Forel et al. (2015, appendix 1) for a complete distribution of the ostracod species. Abbreviations: W., Wuchiapingian stage; jul., occurrence of the conodont Hindeodus julfensis; par., occurrence of the conodont Hindeodus parvus; red line, PTB. Brachiopod bizones: P. ova., Permophricodothyris ovata Biozone; E. lat., Enteletes lateroplicatus Biozone (Angiolini et al. 2010). Colour online. 


\section{MATERIALS AND METHODS}

\section{Samples and extraction}

We processed 118 samples (labelled 03IRxx) spanning $203.2 \mathrm{~m}$ of the upper member of the Nesen Formation and Elikah Formation for ostracod analysis. Only 58 samples were productive: the productive portion $(50.3 \mathrm{~m})$ of the total sampled section is here represented (Fig. 2; detailed species distributions in Forel et al. (2015, appendix 1)); the reader is referred to Gaetani et al. (2009) for a complete record. The calcareous ostracod carapaces have been extracted from the calcareous rocks using the hot acetolysis technique (Lethiers and Crasquin-Soleau 1988; Crasquin-Soleau et al. 2005). Seventy-nine species belonging to 38 genera are identified and figured (Figs 3, 5, 7, 11, 17, 22; see Supporting Information for higher resolution versions of these figures). Four species are new and described below. Nearly all the specimens are represented by complete carapaces, documenting the limited/ absence of postmortem transportation associated with low hydrodynamism and/or rapid burial by high sedimentation rates (Oertli 1971). The large number of juvenile stages confirms this view. Because of poor preservation and/or low abundance, some species are kept in open nomenclature.

\section{Discrimination of ontogenetic series}

As do other crustaceans, ostracods grow by moulting (ecdysis) and stop moulting when they reach Adult stage. In modern or well-preserved fossils, the adults can easily be sorted out from the juveniles by their hinge structure, appendages and inner lamellae (van Morkhoven 1962). The overall preservation of the specimens recovered from the Elikah River section did not allow the study of such characteristics. Specimens are here assigned to their corresponding instar groups based on their size: all the lengths $(\mathrm{L})$ and heights $(\mathrm{H})$ of each species yielding more than five individuals were plotted in traditional $\mathrm{H} / \mathrm{L}$ diagrams to distinguish size clusters corresponding to successive juveniles and adults. For each species under scrutiny, we computed the Kernel density maps (Gaussian Kernel distribution) from the PAST software (Hammer et al. 2001; Hammer and Harper 2005) to robustly distinguish those successive scatter points and reconstruct ontogenetical series for 13 of the recovered species.

Sexual dimorphism: determination and semantic choices

The morphological differences between males and females, called sexual dimorphism, are known for ostracods since the Ordovician (Moore 1961). A recent compilation distinguishes three parts of the ostracods' body (carapace and soft parts) prone to sexually dimorphic patterns (Ozawa 2013):

1. The appendages with the examples of males' asymmetric or larger limbs and the presence/absence of substructures on some limbs of living Podocopida and Myodocopida (Abe and Vannier 1991, 1993; Ikeya and Abe 1996). Different eye structures are also documented for some Myodocopida (Abe and Vannier 1993; Ikeya and Abe 1996).

2. The surface ornamentation of some female Podocopida is heavier than their male counterparts (Tsukagoshi 1998; Kamiya et al. 2001; Smith and Kamiya 2005).

3. The size and shape of the carapaces of both fossil and recent ostracods are dimorphic. The Palaeocopida are known for their strong sexual dimorphism throughout their history from the Ordovician to the Middle Triassic. It globally reflects the presence of brood chambers in the posterior portion of the female carapaces (Moore 1961; Horne et al. 1998). As a general rule, the female carapaces of recent Podocopida are larger, with a more inflated posterior border (e.g. Cytherella, Metacypris, Neonesidea, Paranesidea, Uncicocythere, Xestoleberis; Maddocks and Illiffe 1986; Maddocks 1991; Smith and Hiruta 2004; Smith and Kamiya 2005; Sato and Kamiya 2007). The present work therefore uses the uniformitarianist assumption that morphs displaying a stockier posterior portion are female carapaces. This hypothesis seems fairly satisfactory since eggs have been discovered from posteriorly inflated Myodocopida, therefore identified as female, from the Silurian of Herefordshire, England (Siveter et al. 2007).

The gender of fossil ostracods is traditionally designated by the notions of heteromorphs, corresponding to adult females, and technomorphs being adult males and all juveniles (Moore 1961). However, it is now relatively accepted that sexual dimorphism might appear before the Adult stage in either recent or fossil ostracods (see Discussion for details). Because soft parts are rarely fossilized, the sexually dimorphic patterns preserved for fossil ostracods affect their carapaces. For those fossil species displaying dimorphic structures previous to Adult stage, the notion of technomorph can no longer be taken as valid since it would gather the adult males, juvenile males and juvenile females. In the present analysis, we document several cases of pre-adult sexual dimorphism: for these species, we choose not to use the traditional heteromorph/technomorph notion. 


\section{[Digitare qui]}

Alternatively, we refer to this sexual differentiation by the following binomial notation: gender/developmental stage, for example female/A-1.
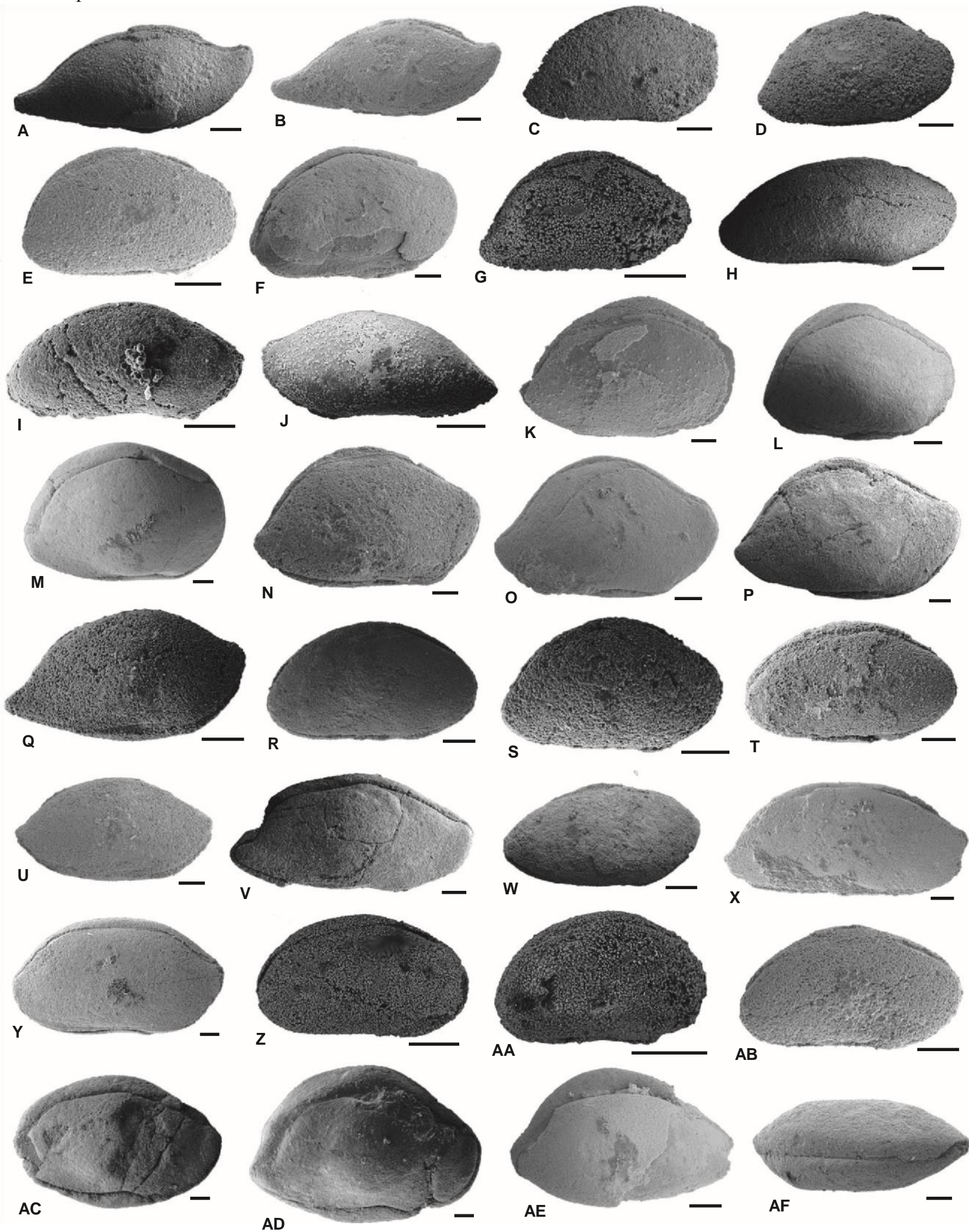
FIG. 3. Ostracods from the Elikah River section, Iran. All specimens are housed in the collections of Universite Pierre et Marie Curie, Paris, France. A-B, Bairdia urodeloformis Chen; A, carapace, right lateral view, P6M3404, sample 03IR200, Late Permian; B, carapace, right lateral view, P6M3405, sample 03IR182, Late Permian. C-G, Bairdia wailiensis Crasquin-Soleau; C, carapace, right lateral view, P6M3406, sample 03IR172, Late Permian; D, carapace, right lateral view, P6M3407, sample 03IR183, Late Permian; E, carapace, right lateral view, P6M3408, sample 03IR198, Late Permian; F, carapace, right lateral view, P6M3409, sample 03IR199, Late Permian; G, carapace, right lateral view, P6M3410, sample 03IR216, Late Permian. H-J, Bairdia cf. subcontracta Chen in Shi and Chen, 1987; H, carapace, right lateral view, P6M3411, sample 03IR200, Late Permian; I, carapace, right lateral view, P6M3412, sample 03IR206, Late Permian; J, carapace, left lateral view, P6M3413, sample 03IR203, Late Permian. K-M, Bairdia cf. bassoni Crasquin in Crasquin et al., 2010a; K, carapace, right lateral view, P6M3414, sample 03IR199, Late Permian; L, carapace, right lateral view, P6M3415, sample 03IR202, Late Permian; M, carapace, right lateral view, P6M3416, sample 03IR206, Late Permian. N-P, Bairdia cf. wailiensis Crasquin-Soleau in Crasquin-Soleau et al., 2006a; N, carapace, right lateral view, P6M3417, sample 03IR199, Late Permian; O, carapace, right lateral view, P6M3418, sample 03IR182, Late

Permian; P, carapace, right lateral view, P6M3419, sample 03IR206, Late Permian. Q, Bairdia cf. wushunbaoi Crasquin in Crasquin et al., 2010a, carapace, right lateral view, P6M3420, sample 03IR200, Late Permian. R-T, Bairdia cf. cahuzaci Forel in Forel and Crasquin, 2011a; R, carapace, right lateral view, P6M3421, sample 03IR171, Late Permian; S, carapace, right lateral view, P6M3422, sample 03IR198, Late Permian; T, carapace, right lateral view, P6M3423, sample 03IR203, Late Permian. U, Bairdia sp. 1, carapace, right lateral view, P6M3424, sample 03IR183, Late Permian. V, Bairdia sp. 2, carapace, right lateral view, P6M3425, sample 03IR206, Late Permian. W, Bairdia? sp. 3, carapace, right lateral view, P6M3426, sample 03IR182, Late Permian. X, Y, Bairdia sp. 4; X, carapace, right lateral view, P6M3427, sample 03IR198, Late Permian; Y, carapace, right lateral view, P6M3428, sample 03IR202, Late Permian. Z-AB, Bairdia sp. 5; Z, carapace, right lateral view, P6M3429, sample 216, Late Permian; AA, carapace, right lateral view, P6M3430, sample 231, Early Triassic; AB, carapace, right lateral view, P6M3431, sample 197, Late Permian. AC-AE, Sinabairdia sp. 1; AC, carapace, right lateral view, P6M3432, sample 03IR201, Late Permian; AD, carapace, right lateral view, P6M3433, sample 03IR201, Late Permian; AE, carapace, right lateral view, P6M3434, sample 03IR202, Late Permian. AF, Orthobairdia sp. 1, carapace, dorsal view, P6M3435, sample 03IR182, Late Permian. All scale bars represent $1001 \mathrm{~lm}$. 


\title{
[Digitare qui]
}

Abbreviations. AB, anterior border; ACA, anterior cardinal angle; ADB, antero-dorsal border; AVB, antero-ventral border; DB, dorsal border; $\mathrm{H}$, height; $\mathrm{H}_{\max }$, maximal height; $\mathrm{H}_{\max } \mathrm{R}, \mathrm{H}_{\max }$ at right valve (for Microcheilinella); L1-L3, lobes; L, length; $\mathrm{L}_{\max }$, maximal length; LV, left valve; PB, posterior border; PCA posterior cardinal angle; PDB, postero-dorsal border; PTB, Permian-Triassic boundary; PVB, postero-ventral border; RV, right valve; SDC, sexual dimorphism of the carapace; $\mathrm{S}_{2}$, median sulcus; VB, ventral border.

\section{SYSTEMATIC PALAEONTOLOGY}

This published work and the nomenclatural acts it contains have been registered in Zoobank: http://zoobank.org/References/ 0EAFA7F83612-4EE5-AB0D-D1A813EBDE37

For the four new species, a full description is given. Only the synonymy and occurrences of other species are specified, and species left in open nomenclature are only illustrated on the plates. The abundance and occurrences of the open nomenclature and cf. species are given in Forel et al. (2015, appendix 2). We follow the systematic classification of Moore (1961) modified after Lethiers (1981) and Horne et al. (2002). All specimens are stored at the Universite Pierre et Marie Curie, Paris, France, collection numbers P6Mxxxx.

\author{
Class OSTRACODA Latreille, 1806 \\ Subclass PODOCOPA Muller, 1894€ \\ Order PODOCOPIDA Muller, $1894 €$ \\ Suborder PODOCOPINA Sars, 1866 \\ Superfamily Bairdioidea Sars, 1887 \\ Family Bairdiidae Sars, 1887 \\ Genus BAIRDIA McCoy, 1844
}

Type species. Bairdia curta McCoy, 1844.

Bairdia urodeloformis Chen in Shi and Chen, 1987 Figure 3A-B

1982 Rectobairdia firmata; Chen and Shi, pl. 7, fig. 10 only.

1987 Bairdia macdonelli Harlton; Shi and Chen, p. 35, pl. 1, figs 1-7, pl. 18, figs 1-4.

1987 Bairdia urodeloformis Chen in Shi and Chen, p. 40, pl. 4, figs 17-23.

2002 Bairdia macdonelli Harlton; Shi and Chen, p. 63, pl. 2, figs 1-4.

2010a Bairdia urodeloformis; Crasquin et al., p. 348, figs 7G-N, 18.

Material. Three complete carapaces, several fragments.

Dimensions. $\mathrm{L}=755-793 \mathrm{~lm} ; \quad \mathrm{H}=333-343 \mathrm{~lm} ; \quad \mathrm{H} / \mathrm{L}=0.43-$

0.44 .

Occurrence. Samples 03IR182, 200, 202, 206, 207, Nesen Formation (Fig. 2; Forel et al. 2015, appendix 1), Elikah River section, Central Alborz, Iran, Changhsingian, Late Permian (this work). Nantong section, Jiangsu Province, China, Changhsingian, Late Permian (Chen and Shi 1982). 


\section{[Digitare qui]}

Matan and Pingding sections, Guangxi Province, Wuchiapingian, Late Permian (Shi and Chen 2002). Meishan section, Zhejiang Province, China, Changhsingian, Late Permian (Shi and Chen 1987; Crasquin et al. 2010a)

Bairdia wailiensis Crasquin-Soleau in Crasquin-Soleau et al., 2006a

Figure $3 C-G$

2006a Bairdia wailiensis Crasquin-Soleau in Crasquin-Soleau et al., p. 60, pl. 1, figs 15-17.

2013b Bairdia wailiensis; Forel et al., fig. 6J-M.

Material. 22 complete carapaces, several fragments.

Dimensions. See Figure 4.

Remarks. Bairdia wailiensis Crasquin-Soleau is known from the Early Triassic of Hungary (Forel et al. 2013b) and Guangxi Province, China (Crasquin-Soleau et al. 2006a). Those specimens are distributed among five ontogenetic stages, from A-4 to Adult (Fig. 4B). The Upper Permian specimens are known from Hungary (Forel et al. 2013b) and the Elikah River section (this work). They are also distributed among five stages, A-4 to Adult, A-2 juveniles only being found from Hungary (Fig. 4A). As for most of the Bairdioidea from the PTB interval whatever the locality, the specimens of Bairdia wailiensis document the strong intraspecific variability affecting all the ontogenetic stages. No clear modification of the shape can be recognized throughout its development apart from the increase in size. Furthermore, no sexual dimorphism is observed.

Occurrence. Samples 03IR161-163, 172, 182, 183, 185, 189, 198-200, 202, 203, 216, 219, Nesen and Elikah formations (Fig. 2; Forel et al. 2015, appendix 1), Elikah River section, Central Alborz, Iran, Changhsingian, Late Permian (this work). Jinya/Waili section, Guangxi Province, South China, Griesbachian?-Spathian, Early Triassic (Crasquin-Soleau et al. 2006a). Balvany North section, Bukk€ Mountains, Hungary, Changhsingian-Griesbachian, Late Permian - Early Triassic (Forel et al. 2013b).

Genus FABALICYPRIS Cooper, 1946

Type species. Fabalicypris wileyensis Cooper, 1946.

Fabalicypris parva Wang, 1978 Figure 5B-G

1978 Fabalicypris parva Wang, p. 293, pl. 2, figs 12 a,b, 13 a,b.

1985 Fabalicypris hungarica; Kozur, p. 82, pl. 17, figs 2, 9, 10.

1987 Bairdiacypris opulenta; Shi and Chen, p. 51, pl. 13, fig. 10.

2004b Fabalicypris parva; Crasquin-Soleau et al., p. 286, pl. 3, figs 4, 5.

2008 Fabalicypris parva; Mette, text-fig. 3, pl. 2, fig. 8.

2010a Fabalicypris parva; Crasquin et al., p. 353, fig. 9A $\mathrm{A}^{0}, \mathrm{~B}^{0} .2010$ Fabalicypris parva; Mette, p. 13.

2012 Fabalicypris parva; Forel, p. 13, fig. 11I.

2013b Fabalicypris parva; Forel et al., fig. 22I-L.

\section{[Digitare qui]}




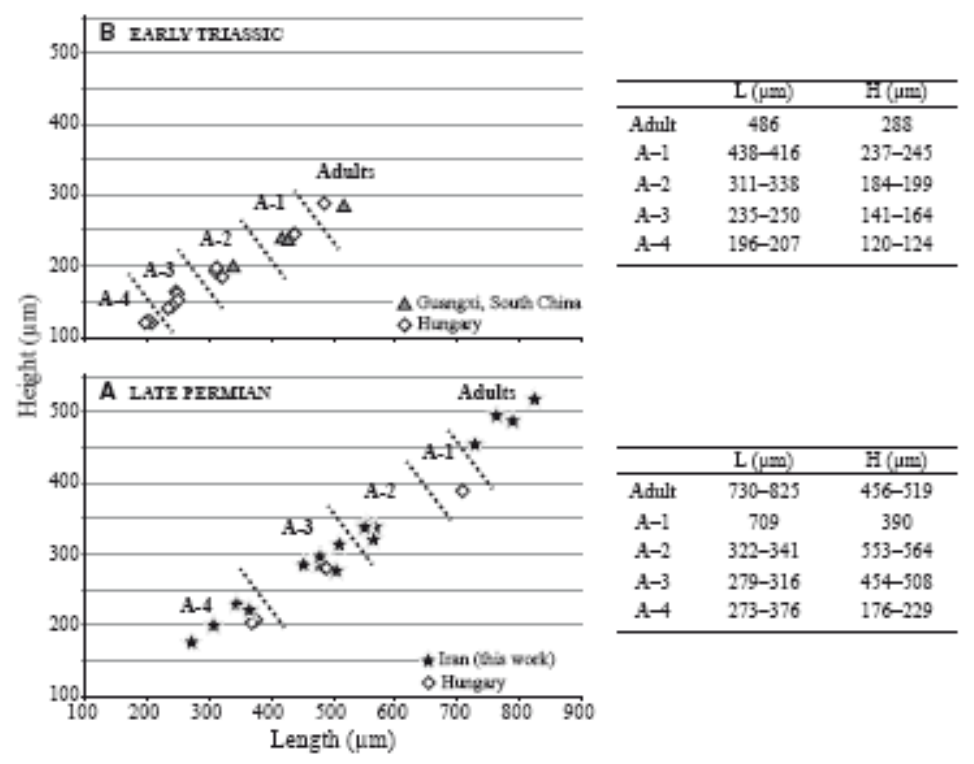

Fig. 4 Length/Height scatter plot of Bairdia wailiensis Crasquin-So leau in the Late Permian leau in the Late Permian (A) and Early Triassic (B). All Upper Permian specimens are from Hungary (Forel et al. 2013b) and Iran (this work), and all Lower Triassic specimens are from Guangxi Province, South China (Crasquin-Soleau et al. 2006a) and Hungary (Forel et al. 2013b)

Material. 28 carapaces, several fragments.

Dimensions. See Figure 6.

\begin{tabular}{lll}
\hline & L $(\mathrm{lm})$ & $\mathrm{H}(\mathrm{lm})$ \\
\hline \multirow{2}{*}{ Adult } & & $340-$ \\
A-1 & $808-820$ & 354 \\
& $660-755$ & $299-$ \\
A-2 & & 342 \\
& $543-588$ & $240-$ \\
A-3 & & 269 \\
& $454-538$ & $192-$ \\
A-4 & & 242 \\
& $400-433$ & $184-$ \\
A-5 & & 201 \\
& $350-379$ & $149-$ \\
A-6 & & 182 \\
& $288-316$ & $138-$ \\
\hline
\end{tabular}


Remarks. The abundant specimens of Fabalicypris parva Wang, 1978 are distributed among seven ontogenetic stages, from A-6 to Adult (Fig. 6). The size of the Carboniferous specimens is not represented here since calculations from the initial pictures did not fit the values provided in the literature (Kozur 1985). From A-6 to A-4, the specimens display relatively conservative morphology, only affected by an overall increase in the dimensions from one stage to the following. In A-3 specimens, two different morphologies begin to show: elongate carapace with PB long and postero-dorsally compressed (labelled 1 on Fig. 6), stockier carapace with PB truncated and close to vertical (labelled 2 on Fig. 6). These morphological differences further develop in A-2 stage where they become more evident. Based on the uniformitarianism exposed previously, the first pattern could correspond to females, for which the copulatory and egg production/brooding organs would have been located at PB. It therefore implies that the sexual dimorphism of internal organs might begin to show on external morphology in A-3 juveniles for the species Fabalicypris parva (see Discussion).

Occurrence. Samples 03IR157, 159, 161-163, 171, 172, 185, 191, 193, 197, 198, 200-202, 206, 207, 212, 213, Nesen Formation (Fig. 2; Forel et al. 2015, appendix 1), Elikah River section, Central Alborz, Iran, Changhsingian, Late Permian (this work). Bukk€ Mountains, Hungary, Late Moscovian, Carboniferous (Kozur 1985). Northern Guizhou and southern Yunnan provinces, WuchiapingianChanghsingian, Late Permian (Wang 1978). Curuk Da€ g section, western Taurus, Turkey, Wuchiapingian- Changhsingian, Late Permian (Crasquin-Soleau et al. 2004b). Zal section, north-western Iran, Changhsingian, Late Permian (Mette 2008, 2010). Meishan section, Zhejiang Province, China, Changhsingian, Late Permian (Shi and Chen 1987; Crasquin et al. 2010a). Dajiang section, Guizhou Province, China, Changhsingian, Late Permian (Forel 2012). Balvany North section, Bukk Mountains, Hungary, Changhsingian, Late Permian€ (Forel et al. 2013b).

Genus PETASOBAIRDIA Chen in Chen and Shi, 1982

Type species. Petasobairdia bicornuta Chen in Chen and Shi, 1982.

Petasobairdia subnantongensis Chen in Shi and Chen, 1987 Figure 7M-O

1982 Petasobairdia nantongensis Chen in Chen and Shi, p. 130, pl. 6, figs 7-9, non figs 1-6.

1987 Petasobairdia subnantongensis Chen in Shi and Chen, p. 47, pl. 8, figs 1-4, pl. 19, figs 8, 9.

2002 Petasobairdia subnantongensis; Shi and Chen, p. 75, pl. 17, figs 12-14.

2008 Petasobairdia nantongensis; Crasquin et al., pl. 4, figs 16, 17.

2010a Petasobairdia subnantongensis; Crasquin et al., p. 350 , fig. $13 \mathrm{~F}-\mathrm{H}$.

Material. Six broken carapaces.

Occurrence. Samples 03IR159, 202, 203, 205, Nesen Formation (Fig. 2; Forel et al. 2015, appendix 1), Elikah River section, Central Alborz, Iran, Changhsingian, Late Permian (this work). Bulla section, Dolomites, Italy, Changhsingian, Late Permian (Crasquin et al. 2008). Nantong section, Jiangsu Province, China, Late Permian (Chen and Shi 1982). Matan and Pingding sections, Guangxi Province, China, Wuchiapingian, Late Permian (Shi and Chen 2002). Meishan section, Zhejiang Province, China, Wuchiapingian-Changhsingian, Late Permian (Shi and Chen 1987; Crasquin et al. 2010a). 
[Digitare qui]
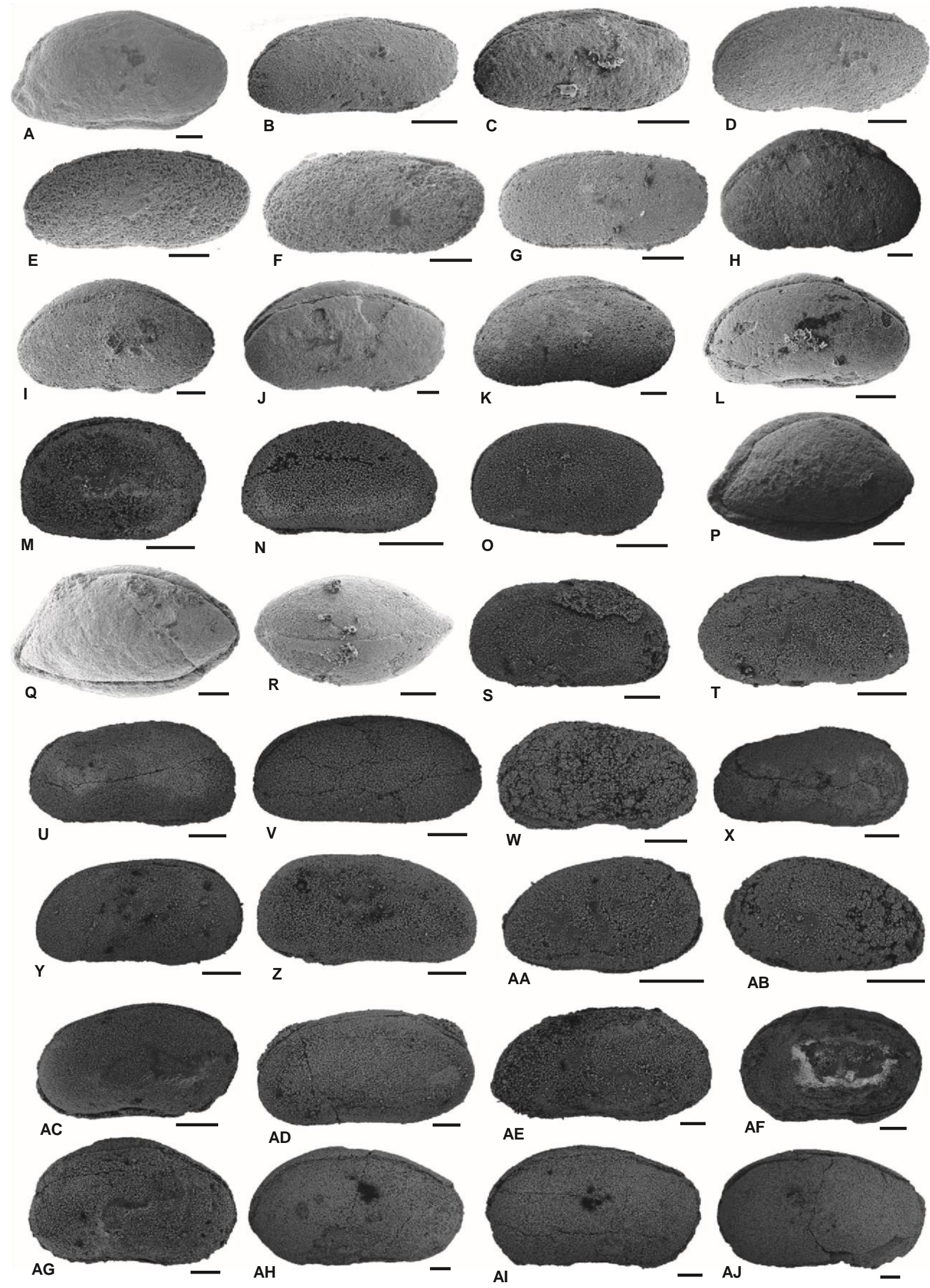


\section{[Digitare qui]}

FIG. 5. Ostracods from the Elikah River section, Iran. All specimens are housed in the collections of Universite Pierre et Marie Curie, Paris, France. A, Orthobairdia sp. 1, carapace, right lateral view, P6M3436, sample 03IR182, Late Permian. B-G, Fabalicypris parva Wang B, carapace, right lateral view, P6M3437, sample 03IR171, Late Permian; C, carapace, right lateral view, P6M3438, sample 03IR201, Late Permian; D, carapace, right lateral view, P6M3440, sample 03IR197, Late Permian; E, carapace, right lateral view, P6M3587, sample 03IR197, Late Permian; F, carapace, right lateral view, P6M3441, sample 03IR197, Late Permian; G, carapace, right lateral view, P6M3442, sample 03IR202, Late Permian. H-L, Fabalicypris? sp. 2; H, carapace, right lateral view, P6M3439, sample 03IR172, Late Permian; I, carapace, right lateral view, P6M3443, sample 03IR203, Late Permian; J, carapace, right lateral view, P6M3487, sample 03IR202, Late Permian; K, carapace, right lateral view, P6M3488, sample 03IR200, Late Permian; L, carapace, right lateral view, P6M3489, sample 03IR206, Late Permian. M-O, Bythocypris sp. 1; M, carapace, right lateral view, P6M3490, sample 03IR216, Late Permian; N, carapace, right lateral view, P6M3491, sample 03IR216, Late Permian; O, carapace, right lateral view, P6M3492, sample 03IR224, Early Triassic. P-R, Kempfia sp. A; P, carapace, right lateral view, P6M3493, sample 03IR204, Late Permian; Q, carapace, right lateral view, P6M3494, sample 03IR202, Late Permian; R, carapace, dorsal view, P6M3495, sample 03IR202, Late Permian. S-V, Liuzhinia cf. antalyaensis Crasquin-Soleau in CrasquinSoleau et al., 2004a; S, carapace, right lateral view, P6M3444, sample 03IR220, Early Triassic; T, carapace, left lateral view, P6M3445, sample 03IR220, Early Triassic; U, carapace, right lateral view, P6M3446, sample 03IR237, Early Triassic; V, carapace, right lateral view, P6M3447, sample 03IR206, Late Permian. W-X, Liuzhinia? sp. 3; W, carapace, left lateral view, P6M3448, sample 03IR225, Early Triassic; X, carapace, right lateral view, P6M3449, sample 03IR239, Early Triassic. Y-Z, Liuzhinia sp. 4; Y, carapace, right lateral view, P6M3450, sample 03IR220, Early Triassic; Z, carapace, left lateral view, P6M3451, sample 03IR220, Early Triassic. AA-AB, Liuzhinia sp. 5; AA, carapace, right lateral view, P6M3452, sample 03IR222, Early Triassic; AB, carapace, left lateral view, P6M3453, sample 03IR225, Early Triassic. AC, Liuzhinia sp. 6, carapace, right lateral view, P6M3454, sample 03IR235, Early Triassic. AD, Bairdiacypris sp. A, carapace, right lateral view, P6M3455, sample 03IR220, Early Triassic. AE, Bairdiacypris sp. 3, carapace, right lateral view, P6M3456, sample 03IR220, Early Triassic. AF, Bairdiacypris? sp. 3, carapace, right lateral view, P6M3457, sample 03IR215, Late Permian. AG-AJ, Praezabythocypris? cf. ottomanensis (Crasquin-Soleau in Crasquin-Soleau et al., 2004a); AG, carapace, right lateral view, P6M3458, sample 03IR229, Early Triassic; AH, carapace, right lateral view, P6M3459, sample 03IR237, Early Triassic; AI, carapace, right lateral view, P6M3460, sample 03IR237, Early Triassic; AJ, carapace, right lateral view, P6M3461, sample 03IR237, Early Triassic. All scale bars represent 100 lm. 


\section{[Digitare qui]}

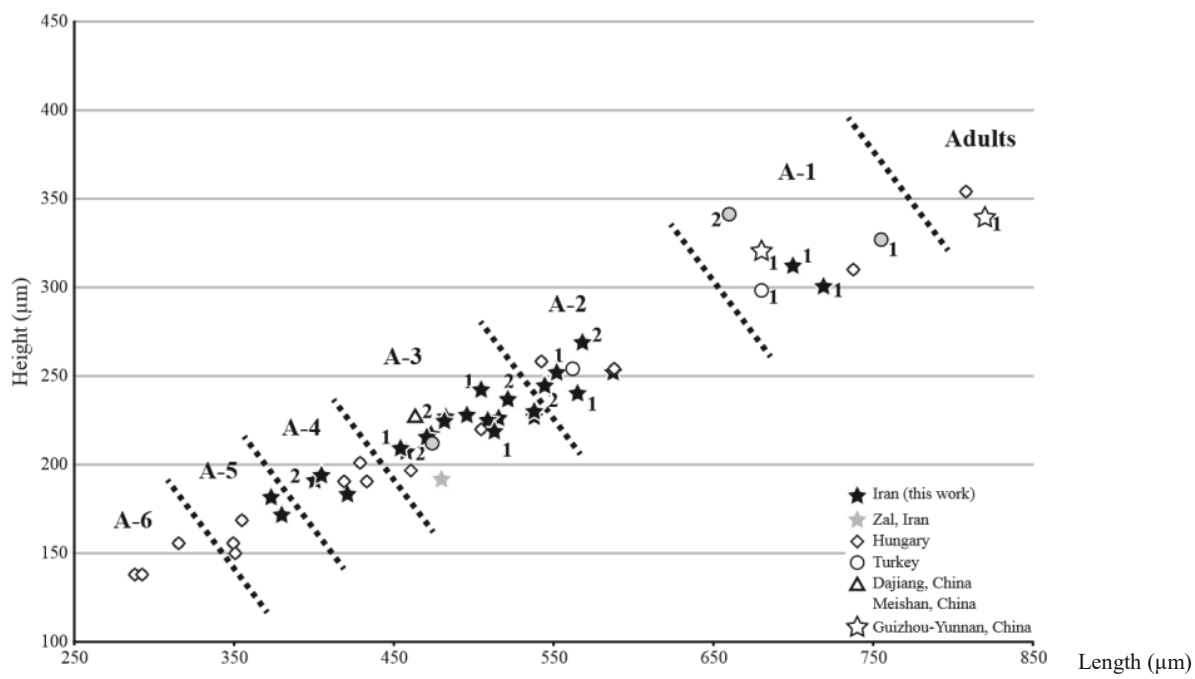

FIG. 6. Length/Height scatter plot of Fabalicypris parva Wang in the Late Permian. All are from Hungary (Forel et al. 2013b), Turkey (CrasquinSoleau et al. 2004b), Iran (Zal section: Mette 2008, 2010; Elikah River section: this work) and South

China (Meishan GSSP, Zhejiang Province: Crasquin et al. 2010a; Guizhou-Yunnan Provinces: Wang 1978; Guizhou Province: Forel et al. 2009, Forel 2012). 1, female; 2, male.

Family ACRATIIDAE Grundel, $1962 €$

Genus ACRATIA Delo, 1930

Type species. Acratia typica Delo, 1930.

\section{Acratia? pervagata Forel sp. nov. \\ Figure $7 \mathrm{P}-\mathrm{U}$}

LSID. urn:1sid:zoobank.org:act:17C40F69-CC70-41A0-ADAC-C99F2F966C4B

2004b Macrocypris cf. M. deducta; Crasquin-Soleau et al., pl. 3. figs 15-16.

2012 Acratia sp. 4; Forel, figs 3J, K.

2012 Acratia? sp. 1; Forel, figs 3G.

2013b Acratia sp. C; Forel et al., fig. 10S, non 10R.

Derivation of name. From the Latin 'prevagatus' for widespread. 


\section{[Digitare qui]}

Types. Holotype: one complete carapace (Fig. 7T), P6M3481, Dimensions. See Figure 8. sample 03IR202; paratype: one complete carapace (Fig. 7R), P6M3479, sample 03IR216.

Type horizon. Sample 03IR202, Elikah River section, Nesen Formation, Changhsingian, Late Permian.

Type locality. Elikah River section (N $36^{\circ} 13^{\circ} 27^{\prime \prime}$, E $\left.51^{\circ} 20^{\circ} 48^{\prime \prime}\right)$, Central Alborz, Iran.

Material. 12 complete carapaces from the Elikah River section, two complete carapaces from the C_Euruk Da_g section, Turkey; two complete carapaces from the Dajiang section, Guizhou Province, China.

Dimensions. See Figure 8.

\begin{tabular}{lll}
\hline & L $(\operatorname{lm})$ & H $(\operatorname{lm})$ \\
\hline & & $365-$ \\
Adult & $632-680$ & 405 \\
A-1 & $552-606$ & $306-$ \\
& & 347 \\
A-2 & $487-522$ & $271-$ \\
& & 325 \\
\hline
\end{tabular}



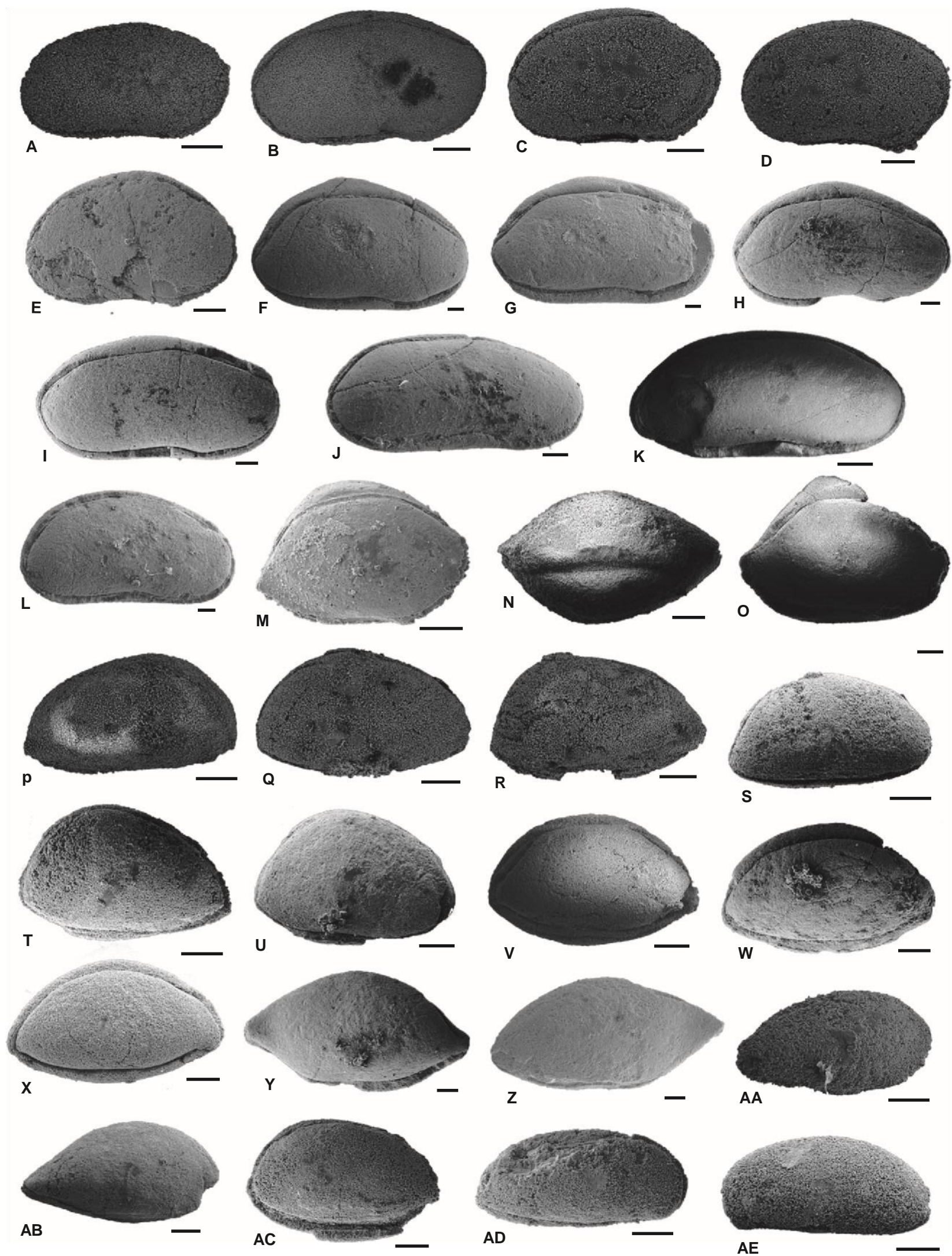


\section{[Digitare qui]}

FIG. 7. Ostracods from the Elikah River section, Iran. All specimens are housed in the collections of Universit_e Pierre et Marie Curie, Paris, France. A-B, Praezabythocypris? cf. ottomanensis (Crasquin-Soleau in Crasquin-Soleau et al., 2004a); A, carapace, right lateral view, P6M3462, sample 03IR239, Early Triassic; B, carapace, right lateral view, P6M3463, sample 03IR239, Early Triassic. C-E, Praezabythocypris cf. pulchraformis Forel in Crasquin et al., 2010a; C, carapace, right lateral view, P6M3464, sample 03IR225, Early Triassic; D, carapace, right lateral view, P6M3465, sample 03IR225, Early Triassic; E, carapace, right lateral view, P6M3466, sample 03IR157, Late Permian. F-I, Praezabythocypris? sp. 1; F, carapace, right lateral view, P6M3467, sample 03IR199, Late Permian; G carapace, right lateral view, P6M3468, sample 03IR199, age Late Permian; H, carapace, right lateral view, P6M3469, sample 03IR206,Late Permian; I, carapace, right lateral view, P6M3470, sample 03IR206, Late Permian. J-L, Praezabythocypris? sp. 2; J, carapace, right lateral view, P6M3471, sample 03IR206, Late Permian; K, carapace, right lateral view, P6M3472, sample 03IR206, Late Permian;

L, carapace, right lateral view, P6M3473, sample 03IR182, Late Permian; M-O, Petasobairdia subnantongensis Chen; M, carapace, right lateral view, P6M3474, sample 03IR202, Late Permian; N, carapace, dorsal view, P6M3475, sample 03IR203, Late Permian; O, carapace, right lateral view, P6M3476, sample 03IR203, Late Permian. P-U, Acratia? pervagata Forel sp. nov.; P, carapace, right lateral view, P6M3477, sample 03IR216, Late Permian; Q, carapace, right lateral view, P6M3478, sample 03IR216, Late Permian; R, paratype, carapace, right lateral view, P6M3479, sample 03IR216, Late Permian; S, carapace, right lateral view, P6M3480, sample 03IR203, Late Permian; T, holotype, carapace, right lateral view, P6M3481, sample 03IR202, Late Permian; U, carapace, right lateral view, P6M3482, sample 03IR201, Late Permian. V-X, Acratia qinglongensis Wang, 1978; V, carapace, right lateral view, P6M3483, sample 03IR171, Late Permian; W, carapace, right lateral view, P6M3484, sample 03IR201, Late Permian; X, carapace, right lateral view, P6M3485, sample 03IR202, Late Permian. Y-Z, Acratia cf. permiana Zalanyi, 1974; Y, carapace, left lateral view, P6M3486, sample 03IR201, Late Permian; Z, carapace, right lateral view, P6M3487, sample 03IR182, Late Permian. AA-AB, Acratia cf. subfusiformis Wang, 1978; AA, carapace, right lateral view, P6M3488, sample 03IR162, Late Permian; AB, carapace, right lateral view, P6M3489, sample 03IR171, Late Permian. AC, Acratia? sp. 1, carapace, right lateral view, P6M3490, sample 03IR207, Late Permian. AD-AE, Acratia sp. A; AD, carapace, right lateral view, P6M3491, sample 03IR157, Late Permian; AE, carapace, left lateral view, P6M3492, sample 03IR200, Late Permian. All scale bars represent $100 \mathrm{~lm}$.



FIG. 8. Length/Height scatter plot of Acratia? pervagata Forel sp. nov. All specimens are from Turkey (Crasquin-Soleau et al. 2004b), Guizhou Province, South China (Forel et al. 2009; Forel 2012), and Iran (this work).

Description. The carapace of the present species is subtriangular in lateral view, strongly postplete to close to amplete. The LV overlaps RV all around the carapace with maximum at VB. Its surface is smooth. The contour of dorsal, anterior and posterior borders is similar at both valves. The ADB is short ( $25 \%$ of $\mathrm{L}_{\max }$ ) and bent towards $\mathrm{AB}$ with an angle close to 60 . Its transition with $\mathrm{DB}$ is slightly angulated in some specimens 
only (160). The $\mathrm{DB}$ is about $60 \%$ of $\mathrm{L}_{\max }$ and gently bent towards $\mathrm{ADB}$ with an angle close to 15 . The PDB is slightly shorter than ADB (15\% of $\mathrm{L}_{\max }$ ) and strongly bent towards PB (130). The transition of DB with ADB and PDB is located at similar $\mathrm{H}$ close to the dorsum (90\% of $\mathrm{H}_{\max }$ ). The $\mathrm{PB}$ is large (110) with a maximum of convexity located in the lower quarter of $\mathrm{H}_{\max }$. The $\mathrm{AB}$ is close to 90 with a maximum of convexity located higher $\left(40 \%\right.$ of $\mathrm{H}_{\max }$ ). The ventrum is evenly convex at $\mathrm{RV}$ and divided into three distinct portions. The AVB and PVB have similar lengths of about $35-40 \%$ of $\mathrm{L}_{\max }$. The AVB is slightly convex, and its transition with VB is slightly angulated (160). The VB is concave and about $25 \%$ of $\mathrm{L}_{\max }$, and its transition with PVB is close to flat. The PVB is slightly convex. The LV is broadly convex at ventrum with AVB, VB and PVB not distinct (Fig. 9).

Remarks. Specimens of this new species have already been reported from the Late Permian of Turkey (Crasquin-Soleau et al. 2004b), Hungary (Forel et al. 2013b) and South China (Forel 2012) under different identifications, mostly open nomenclature. It is here recorded for the first time to cross the PTB. Acratia? pervagata Forel sp. nov. differs from A. hvorostaniensis Egorov, 1953 from the Frasnian of Russia by its less convex VB and asymmetric shape in lateral view. It is also distinct from $A$. posteroinclinata Kozur, 1985 from the Late Permian of Hungary by its marked DB-ADB, less steep PDB, posterior maximum of convexity located slightly more dorsally, and more rounded $\mathrm{AB}$ and $\mathrm{PB}$. Through its three reconstructed ontogenetic stages, no clear shape modification is identified, the intraspecific variations being here very strong, as for most of the Bairdioidea of the PTB transition.

Occurrence. Samples 03IR195, 201-204, 207, 216, 220, Nesen and Elikah formations (Fig. 2; Forel et al. 2015, appendix 1), Elikah River section, Central Alborz, Iran, Changhsingian-Griesbachian, Late Permian - Early Triassic (this work). Curuk Da€ g section, Western Taurus, Turkey, Wuchiapingian, Late Permian (Crasquin-Soleau et al. 2004b). Dajiang section, Guizhou Province, China, Changhsingian, Late Permian (Forel 2012). Balvany North section, Bukk Mountains, Hungary, Changhsingian, Late Permian (Forel et al. 2013b). 
[Digitare qui]

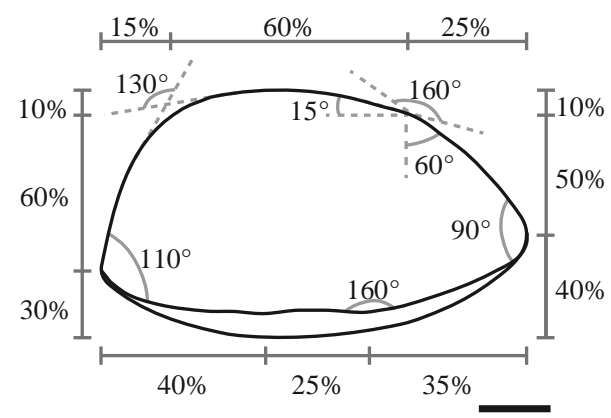

FIG. 9. Scheme of the contour of Acratia? pervagata Forel sp. nov. showing all angles and proportions of the carapace.

Acratia qinglongensis Wang, 1978 Figure 7V-X

1978 Acratia qinglongensis Wang, pp. 295-296, pl. IV, fig. 9a-d.

Material. 13 carapaces, several fragments.

Dimensions. See Figure 10.

\begin{tabular}{lll}
\hline & L $(\operatorname{lm})$ & H $(\operatorname{lm})$ \\
\hline Adult & & \\
A-1 & 732 & 430 \\
& $632-648$ & $353-$ \\
A-2 & & 393 \\
& $561-605$ & $311-$ \\
\hline
\end{tabular}


Remarks. The specimens of Acratia qinglongensis are distributed among three ontogenetic stages, A-2 to Adult (Fig. 10). Through the reconstructed portion of the development, the carapace becomes stockier, elongated specimens mostly corresponding to A-3, and $\mathrm{AB}$ migrates dorsally. The material is, however, insufficient to detect any possible sexual dimorphism.

Occurrence. Samples 03IR163, 171, 172, 201-204, 206, Nesen Formation (Fig. 2; Forel et al. 2015, appendix 1), Elikah River section, Central Alborz, Iran, Changhsingian, Late Permian (this work). Western Guizhou-north-eastern Yunnan provinces, South China, Late Permian (Wang 1978).

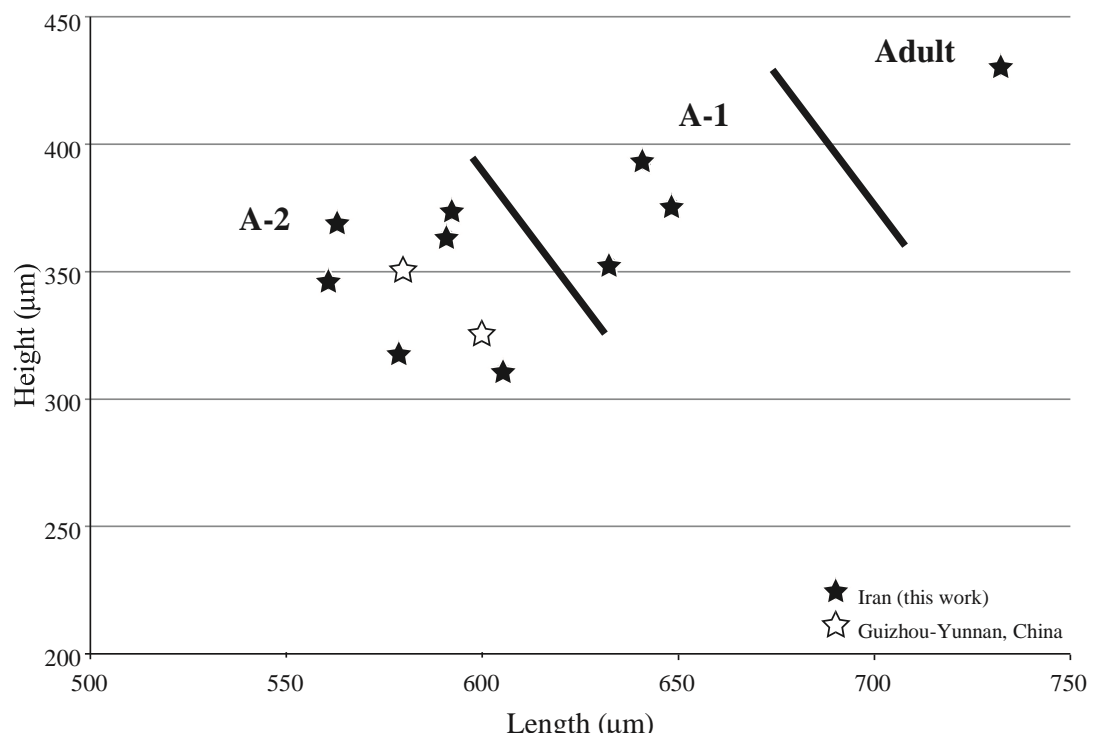

FIG. 10. Length/Height scatter plot of Acratia qinlongensis Wang. All specimens are from GuizhouYunnan Provinces, South China (Wang 1978) and Iran (this work). 
Material. 34 carapaces, several fragments.

Dimensions. See Figure 12.

\begin{tabular}{lll}
\hline & L $(\mathrm{lm})$ & H $(\mathrm{lm})$ \\
\hline \multirow{2}{*}{ Adult } & & $298-$ \\
A-1 & $568-601$ & 345 \\
& $520-505$ & $231-$ \\
A-2 & & 315 \\
& $455-486$ & $219-$ \\
A-3 & & 283 \\
& $392-422$ & $232-$ \\
A-4 & & 248 \\
& $334-369$ & $163-$ \\
A-5 & & 223 \\
& $261-314$ & $142-$ \\
\hline
\end{tabular}

Remarks. All the specimens known for the species Microcheilinella rectodorsata Forel, 2010 gather into six successive ontogenetic stages, from A-5 to Adult (Fig. 12). Among each of them, two morphologies are distinguished: (1) the stocky and ovoid carapaces showing a round PB with a maximum of convexity around mid- $\mathrm{H}_{\max }$ (i.e. $50 \%$ of $\mathrm{H}_{\max }$ ), these are the largest specimens of each stage; and (2) the elongated carapaces displaying tapered PB with maximum of convexity close to the ventrum, which correspond to the smallest specimens of each stage. These two groups could, respectively, correspond to females and males. This interpretation is coherent with the previous report of subelliptical and more elongated morphs among specimens of M. mendelgrammi (Early Carboniferous of South China), the latter possibly being males (Olempska 2001). If so, our data would document the appearance of sexually dimorphic carapaces in stage A-5 at least (see Discussion).

Occurrence. Samples 03IR159, 161, 172, 182, 186, 197, 198, 200- 207, Nesen Formation (Fig. 2; Forel et al. 2015, appendix 1), Elikah River section, Central Alborz, Iran, Changhsingian, Late Permian (this work). Meishan section, Zhejiang Province, China, Changhsingian, Late Permian (Crasquin et al. 2010a).

Microcheilinella alborzella Forel sp. nov.

Figure $11 \mathrm{G}-\mathrm{Q}$

LSID. urn:1sid:zoobank.org:act:73317504-926A-4445-A21476639B43D664

Derivation of name. From the type locality in the Alborz Mountains, Iran.

Types. Holotype: one complete male carapace (Fig. 11J), P6M3502, sample 03IR206; paratype: one complete female carapace (Fig. 11O), P6M3507, sample 03IR202.

Dimensions. See Figure 13.

\begin{tabular}{lll}
\hline & L $(1 \mathrm{~lm})$ & $\mathrm{H}(\mathrm{lm})$ \\
\hline & & \\
Adult & $440-505$ & $279-$ \\
& & 339
\end{tabular}




\begin{tabular}{lll} 
A-1 & $361-437$ & $231-$ \\
& & 302 \\
A-2 & 316 & 214 \\
A-3 & 252 & 185 \\
\hline
\end{tabular}

Diagnosis. A species of Microcheilinella with straight, horizontal DB, AB broadly rounded and vertical, overlap strong all around the carapace.

\section{Description}

o. The male carapace is ovoid and relatively elongate in lateral view, amplete to slightly preplete; it is diamond-shaped in dorsal view with Wmax in the anterior third of $\mathrm{L}$; the surface is smooth.

The LV is massive, ovoid at $\mathrm{AB}$ and truncated at $\mathrm{PB}$; it strongly overlaps $\mathrm{RV}$ at all borders, with a maximum at DB in most cases, thickness varying from 8 to $25 \%$ of $\mathrm{H}_{\max }$ at both $\mathrm{DB}$ and $\mathrm{VB}$ (Fig. 14); the ADB is straight to slightly convex and bent towards $\mathrm{AB}$ with an angle close to 30 ; the DB is strongly convex; the PDB is straight, long and bent towards PB with an angle around 25; the AB is rounded with large radius of convexity, whose maximum is located around mid- $\mathrm{H}_{\max }$; the $\mathrm{PB}$ is angulated $(100)$ with a small radius of convexity located in the upper third of $\mathrm{H}_{\max }$; its shape is asymmetrical with a 60 angle in the upper portion and 20 in the lower portion; the AVB is short, convex and strongly bent towards $\mathrm{AB}$ (30); the VB is slightly convex; the PVB is convex to straight for some specimens, long (more than half $\mathrm{L}_{\max }$ ) and bent dorsally at an angle close to 20 .

The $\mathrm{RV}$ is rectangular at $\mathrm{AB}$ and tapered at $\mathrm{PB}$; its $\mathrm{H}_{\max }$ is located around anterior half; the $\mathrm{ADB}$ and $\mathrm{DB}$ are undifferentiated, straight and long; the PDB is short, straight to convex and bent downward to PB with an angle close to 90; the transition between ADB and AB is marked by an obtuse angle (115); the $\mathrm{AB}$ is nearly vertical to slightly convex with large radius of curvature, maximum located around the mid- $\mathrm{H}_{\max }$ of the valve; its transition with AVB is of acratian type also marked by an obtuse angle (125) located at the ventrum; the PB displays a narrow radius of convexity (90) with a maximum above mid- $\mathrm{H}_{\max }$ of the valve; it is located below the PB at LV; the VB displays contours similar to LV.

9. The female carapace is elongate, rectangular and amplete in lateral view; it is lenticular in dorsal view, with Wmax posterior to mid-Lmax; the LV overlaps RV all around the carapace with a maximum of overlap at DB (6-20\% of $\mathrm{H}_{\max }$; Fig. 14); the surface is smooth.

The LV is ovoid; ADB is straight, long (55\% of $\mathrm{L}_{\max }$ ) and slightly bent towards $\mathrm{AB}(25)$; the $\mathrm{DB}$ is convex and short; the PDB is about $45 \%$ of $\mathrm{L}_{\max }$, straight and bent towards $\mathrm{PB}$ with angle similar to $\mathrm{ADB}-\mathrm{AB}$; the $\mathrm{AB}$ is rounded with a large radius of convexity, whose maximum is located close to mid- $\mathrm{H}_{\max }$; the PB is tapered with narrower radius of convexity (120), whose maximum located slightly above mid- $\mathrm{H}_{\max }$; the undifferentiated AVB and VB are convex and long (80\% of $\mathrm{Lmax}$ ); the PVB is straight and bent towards PB with an angle close to 30 . The RV is relatively homogeneously rectangular; its $\mathrm{PDB}, \mathrm{ADB}$ and $\mathrm{DB}$ are straight and in continuity; the $\mathrm{AB}$ is broadly rounded to vertical with a maximum of convexity around mid- $\mathrm{H}_{\max }$ or below mid- $\mathrm{H}_{\max }$ in some specimens; its transition with AVB is close to 90 and located at VB, and the PB is similar in shape to AB but slightly narrower; the AVB, VB and PVB are also in continuity, straight and long; the ventrum and dorsum are close to parallel and mirror image of each other. 
[Digitare qui]


[Digitare qui] 
FIG. 11. Ostracods from the Elikah River section, Iran. All specimens are housed in the collections of Universite Pierre et Marie Curie, Paris, France. A, Acratia sp. B, carapace, right lateral view, P6M3493, sample 03IR192, Late Permian. B, Acratia sp. C, carapace, left lateral view, P6M3494, sample 03IR203, Late Permian. C-F, Microcheilinella rectodorsata Forel in Crasquin and Forel, 2010a; C, carapace, o', right lateral view, P6M3495, sample 03IR202, Late Permian; D, carapace, , right lateral view, P6M3496, sample 03IR159, Late Permian; E, carapace, ơ, right lateral view, P6M3497, sample 03IR205, Late Permian; F, carapace, ơ, right lateral view, P6M3498, sample 03IR206, Late Permian. G-Q, Microcheilinella alborzella Forel sp. nov.; G, carapace, ơ', right lateral view, P6M3499, sample 03IR202, Late Permian; H, carapace, o", right lateral view, P6M3500, sample 03IR161, Late Permian; I, carapace, o", right lateral view, P6M3501, sample 03IR206, Late Permian; J, holotype, carapace, ơ, right lateral view, P6M3502, sample 03IR206, Late Permian; K, carapace, ox, right lateral view, P6M3503, sample 03IR206, Late Permian; L, carapace, ox, dorsal view, P6M3504, sample 03IR206, Late Permian; M, carapace,, , right lateral view, P6M3505, sample 03IR172, Late Permian; N, carapace,, , right lateral view, P6M3506, sample 03IR182, Late Permian; O, paratype, carapace, + , right lateral view, P6M3507, sample 03IR202, Late Permian; P, carapace,, , dorsal view, P6M3508, sample 03IR200, Late Permian; Q, carapace, \%, right lateral view, P6M3509, sample 03IR202, Late Permian. RT, Callicythere sp. 1; R, carapace, left lateral view, P6M3510, sample 03IR219, Late Permian; S, carapace, right lateral view, P6M3511, sample 03IR221, Early Triassic; T, carapace, left lateral view, P6M3512, sample 03IR222, Early Triassic. U-Z, Basslerella superarella Crasquin sp. nov.; U, holotype, carapace, right lateral view, P6M3513, sample 03IR203, Late Permian; V, carapace, dorsal view, P6M3514, sample 03IR203, Late Permian; W, carapace, right lateral view, P6M3515, sample 03IR162, Late Permian; X, carapace, right lateral view, P6M3516, sample 03IR182, Late Permian; Y, carapace, right lateral view, P6M3517, sample 03IR202, Late Permian; Z, paratype, carapace, right lateral view, P6M3518, sample 03IR203, Late Permian. AA, Arqoviella sp. 1, carapace, right lateral view, P6M3519, sample 03IR235, Early Triassic. AB, Paracypris gaetanii Crasquin-Soleau, carapace, right lateral view, P6M3520, sample 03IR159, Late Permian. AC-AD, Paracypris cf. gaetanii Crasquin-Soleau; AC, carapace, right lateral view, P6M3521, sample 03IR223, Early Triassic; AD, carapace, left lateral view, P6M3522, sample 03IR223, Early Triassic. AE, Orthocypris sp. 2, carapace, left lateral view, P6M3523, sample 03IR203, Late Permian. AF, Cyathus caperata (Guan), carapace, right lateral view, P6M3524, sample 03IR203, Late Permian. All scale bars represent $100 \mathrm{~lm}$.

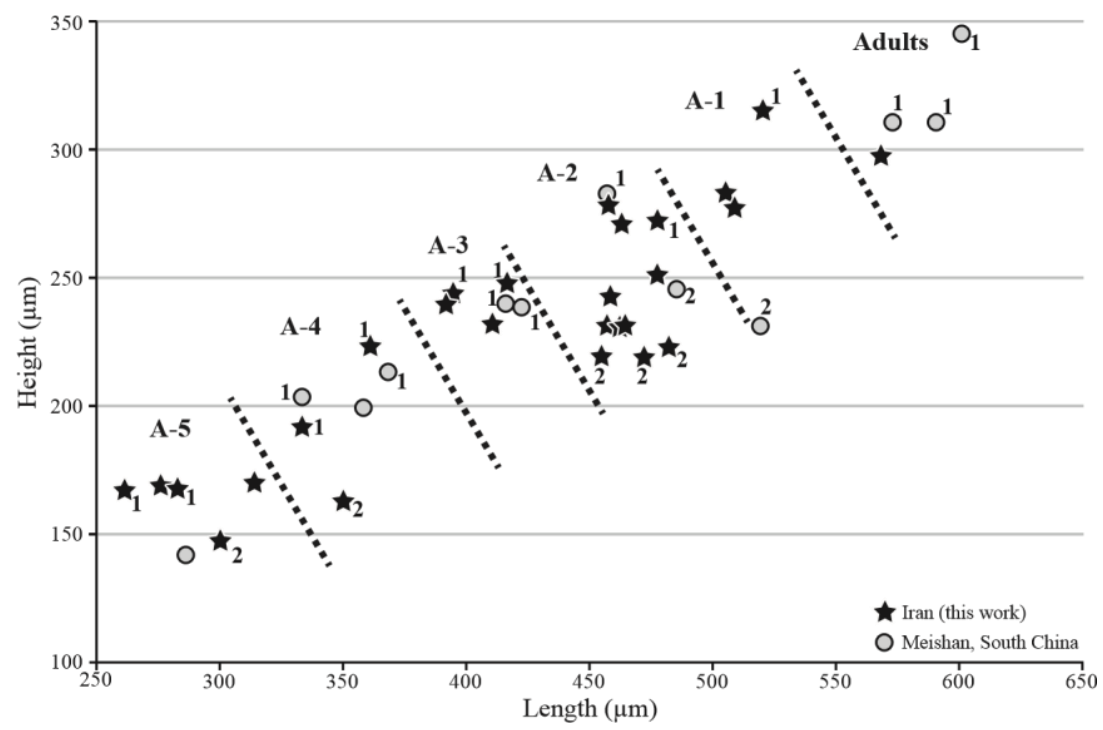

FIG. 12. Length/Height scatter plot of Microcheilinella rectodorsata Forel 2010. All specimens are from Meishan GSSP, Zhejiang Province, South China (Crasquin et al. 2010a) and Iran (this work). 1, female; 2, male. 


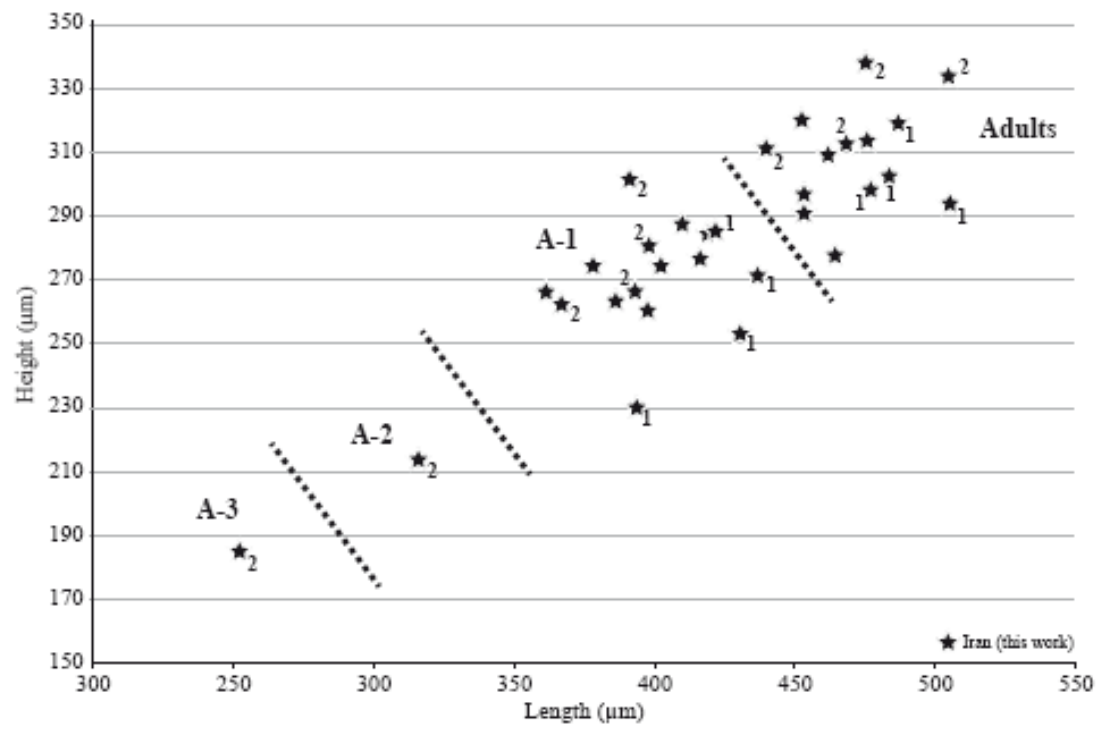

FIG. 13. Length/Height scatter plot of Microcheilinella alborzella Crasquin sp. nov. All specimens are from Iran (this work); 1 , female; 2 , male.

Remarks. Microcheilinella alborzella Forel sp. nov. differs from M. venusta Chen, 1958 from the Early Permian of the Nanking Province, China (Chen 1958), by its stronger overlap and straighter dorsal and ventral borders. It is also different from $M$. peroi peroi Kozur, 1985 from the Early Abadehian (Wuchiapingian) of the Bukk Moun-€ tains, Hungary, by its straighter dorsal and ventral borders. Some specimens display a Bairdia-like PB similar to M. speciosa Chen, 1958 from the Early Permian of Nanking Province, China, but the nature of the overlap drives us to consider M. alborzella Crasquin sp. nov. as a different species. M. alborzella Forel sp. nov. is close to M. sp. C sensu Forel et al. 2013b from the Early Triassic of the Balvany North section, Hungary, but it is shorter with straighter DB and bent steeper towards PB. It is also similar in outline to M. larianovae Polenova, 1955 from the Middle Devonian of the Urals, but this species displays a maximum of overlap at PVB and very short DB at RV. The specimens of M. alborzella Forel sp. nov. recovered from the present section are distributed among four ontogenetic stages, from A-3 to Adult (Fig. 13). The shape is relatively conservative through its development. A-3 and A-2 specimens show tapered $\mathrm{PB}$, corresponding to male morphs. Two morphologies differentiate during A-1 with elongated specimens possessing broadly rounded PB corresponding to female morphs (labelled 1 on Fig. 13) and shorter specimens with tapered PB corresponding to male 
morphs (labelled 2 on Fig. 13). They document the appearance of sexual dimorphism in A-1 juvenile for Microcheilinella alborzella Forel sp. nov.

Occurrence. Samples 03IR161, 162, 172, 182, 183, 186, 188, 200, 201-203, 205, 206, Nesen Formation (Fig. 2; Forel et al. 2015, appendix 1), Elikah River section, Central Alborz, Iran, Changhsingian, Late Permian (this work).
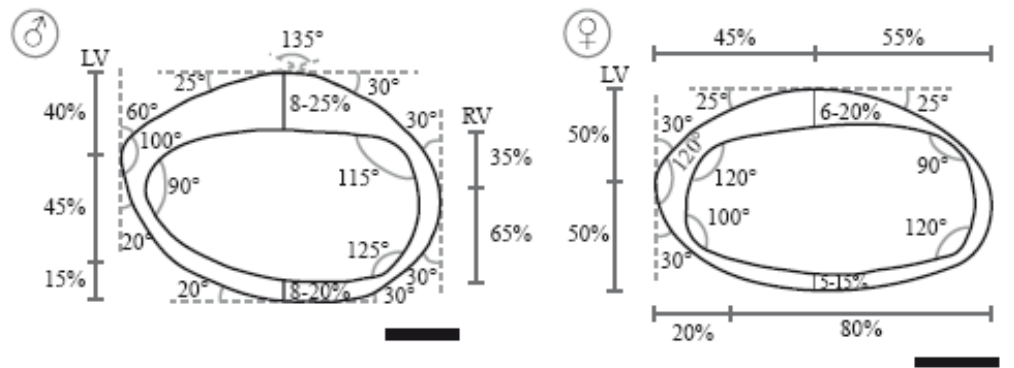

FIG. 14. Scheme of the contour of Microcheilinella alborzella Crasquin sp. nov. showing all angles and proportions of the carapace. RV, height proportions of right valve; $\mathrm{LV}$, height proportions of left valve.

\author{
Superfamily CYTHEROIDEA Baird, 1850 \\ Family CYTHERIDEIDAE Sars, 1925 \\ Genus BASSLERELLA Kellett, 1935
}

Type species. Basslerella crassa Kellett, 1935.

Basslerella superarella Crasquin sp. nov. Figure $11 \mathrm{U}-\mathrm{Z}$

LSID. urn:lsid:zoobank.org:act:9A98BF04-577A-4E58-85C5A8C4294829EC

Derivation of name. From the Latin superare for survive.

Types. Holotype: one complete carapace (Fig. 11U), P6M3513, sample 03IR203; paratype: one complete carapace (Fig. 11Z), P6M3518, sample 03IR203.

Type horizon. Sample 03IR203, Elikah River section, Nesen Formation, Changhsingian, Late Permian (Fig. 2).



Material. 66 complete carapaces, several fragments.

Dimensions. $\mathrm{L}=222-477 \mathrm{~lm}, \quad \mathrm{H}=147-345 \mathrm{~lm}, \mathrm{H} / \mathrm{L}=0.6-0.78$ (Fig. 15). 
Diagnosis. A species of Basslerella with high $\mathrm{H} / \mathrm{L}$ ratio (up to 0.78 ) with strongly tapered and elongated posterior half of the carapace; free margin of ADB border pinched.

Description. The carapace of the new species is elongate, strongly asymmetrical, drop-shaped with posterior half of the carapace tapered in lateral view. It is preplete with $\mathrm{H}_{\max }$ occurring at the transition between $\mathrm{ADB}$ and DB in the anterior one-third of $\mathrm{L}_{\max }$ or in front. The thin overlap of LV all around RV is visible at some specimens only. It displays a lenticular shape in dorsal view with Wmax slightly backward from $L_{\max }$ The surface is smooth.

The ADB is long ( $40 \%$ of $\mathrm{L}_{\max }$ ), slightly convex and bent towards $\mathrm{AB}$ with an angle of 40 (Fig. 16). Its transition to DB is rounded and located around $40 \%$ of $\mathrm{L}_{\max }$; it is located around $30 \%$ of $\mathrm{H}_{\max }$ higher than the DB-PDB transition. The DB is straight and of middle length ( $45 \%$ of $\mathrm{L}_{\max }$ ); its posterior portion is bent ventrally with an angle close to 45 . The PDB is only $15 \%$ of $\mathrm{L}_{\max }$ and vertical to slightly convex. The $\mathrm{PB}$ is narrow, vertical to convex with a small radius of curvature whose maximum is located around the lower quarter of $\mathrm{H}_{\max }$. The $\mathrm{AB}$ is broadly rounded with a maximum of convexity located slightly below (in the holotype) to above mid- $\mathrm{H}_{\max }$ (Fig. 11X); it is fringed by a pinched area. The AVB is of middle length (30\% of $\mathrm{L}_{\max }$ ), gently rounded and steeply bent towards $\mathrm{AB}$. The VB is long (50\% of $\mathrm{L}_{\max }$ ), convex to close to straight at LV and slightly concave at RV. The PVB is short.

Remarks. The abundant specimens of Basslerella superarella Crasquin sp. nov. document strong variations in the $\mathrm{H}$ and $\mathrm{L}$ of the posterior part of the carapace. Strong variations also affect PB, from convex to close to vertical. However, contrary to other species in the present work, these intraspecific disparities are continuous and homogenous and cannot be related to sexual dimorphism based on the present data. Basslerella superarella Crasquin sp. nov. differs from most of the known Basslerella species by its pinched $\mathrm{AB}$ and elongated posterior half resulting in elongate and tapered lateral profile. The Permian specimens are distributed among six ontogenetic stages, from A-5 to Adult (Fig. 15A), while the Triassic ones correspond to stages A-4 to Adult (Fig. 15B). The ontogenetic development of Basslerella superarella Crasquin sp. nov. seems to be mostly marked by an inflation of the posterior portion of the carapace. 




FIG. 15. Length/Height scatter 350 plot of Basslerella superarella Crasquin sp. nov. All specimens are from Iran (this work).

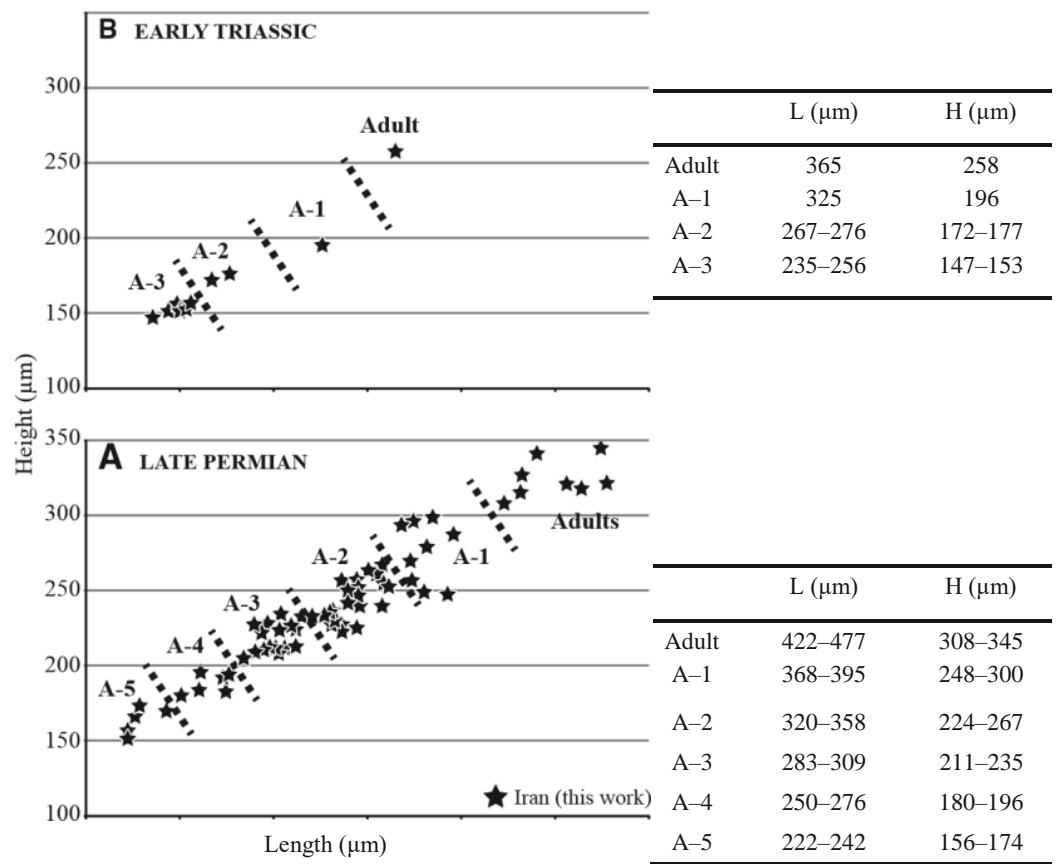

FIG. 16. Scheme of the contour of Basslerella superarella Crasquin sp. nov. showing all angles and proportions of the carapace.

Occurrence. Samples 03IR157, 162, 182, 183, 185, 192, 198, 200-203, 206, 212, 213, 216, 220, 222, 223, 230, 234, Nesen and Elikah formations (Fig. 2; Forel et al. 2015, appendix 1), Elikah River section, Central Alborz, Iran, Changhsingian-Griesbachian, Late Permian - Early Triassic (this work).

Superfamily CYPRIDOIDEA Baird, 1845 Family PARACYPRIDIDAE Sars, 1923

Genus PARACYPRIS Sars, 1910

Type species. Paracypris polita Sars, 1866. 


\section{[Digitare qui]}

1992 Paracypris sp.; Hao, p. 42, pl. 1, fig. 24.

2005 Paracypris sp. sensu Hao 1999 (sic); CrasquinSoleau and Kershaw, pl. I, figs 7-9.

2006a Paracypris gaetanii Crasquin-Soleau in CrasquinSoleau et al., p. 64, pl. 4, figs 1-4.

2008 Paracypris gaetanii; Crasquin et al., p. 249, pl. 4, fig. 11.

2009 Paracypris gaetanii; Forel et al., p. 819, fig. 4 (5).

2011a Paracypris gaetanii; Forel and Crasquin, figs $3 \mathrm{~F}^{0}-4 \mathrm{~A}$.

2012 Paracypris gaetanii; Forel, p. 22, figs 13T-X.

2014 Paracypris gaetanii; Forel, p. 14, figs 12N-Q.

Material. One carapace.

Dimensions. $\mathrm{L}=210 \mathrm{~lm}, \mathrm{H}=454 \mathrm{~lm}, \mathrm{H} / \mathrm{L}=0.46$.

Remarks. Based on the ontogenetic stages of all the known specimens of Paracypris gaetanii described in Forel (2014), the present specimen belongs to the A-2 stage.

Occurrence. Sample 03IR159, Nesen Formation (Fig. 2; Forel et al. 2015, appendix 1), Elikah River section, Central Alborz, Iran, Changhsingian, Late Permian (this work). Cur€ uk Da€ g section, Griesbachian, Early Triassic, Western Taurus, Turkey (Crasquin-Soleau et al. 2004a, b; Forel 2014). Griesbachian, Early Triassic, Zhenfeng, Guizhou Province, China (Hao 1992). Laolongdong section, Griesbachian, Early Triassic, Sichuan Province, China (Crasquin-Soleau and Kershaw 2005). Jinya/Waili section, Griesbachian, Early Triassic, Guangxi Province, China (Crasquin-Soleau et al. 2006a). Bulla section, Griesbachian, Early Triassic, Dolomites, Southern Alps, northern Italy (Crasquin et al. 2008). Dajiang section, Guizhou Province, China, Changhsingian-Griesbachian, Late Permian - Early Triassic (Forel et al. 2009; Forel 2012). Meishan section, Griesbachian, Early Triassic, Zhejiang Province, China (Forel and Crasquin 2011 a).

Order PALAEOCOPIDA Henningsmoen, 1953€ Suborder BEYRICHICOPINA Scott, 1961

Superfamily OEPILELLOIDEA Jaanusson, 1957 Family APARCHITIDAE Jones, 1901

Genus CYATHUS Roth and Skinner, 1930

Type species. Cyathus ulrichi Roth and Skinner, 1930.

Cyathus caperata (Guan in Guan et al., 1978) Figures 11AF; 17A, B

1978 Sinocoelonella caperata Guan in Guan et al., p. 149, pl. 37, fig. 17; pl. 38, fig. 1.

1986 Cyathus caperata; Chen and Bao, p. 111, pl. 4, fig. 3.

1987 Cyathus caperata; Shi and Chen, p. 32, pl. 10, figs 10-18.

2008 Cyathus caperata; Yuan, pp. 47-48, pl. 2, figs 4-6.

2009 Cyathus caperata; Yuan et al., pl. 1, fig. 15.

2010a Cyathus caperata; Crasquin et al., pp. 332-334, figs 3A-D.

2012 Cyathus caperata; Chitnarin et al., p. 806, fig. 4A-D.

2014 Cyathus caperata; Burrett et al., p. 14, 16, fig. 12s, t.

Material. Five complete carapaces, several fragments.

Dimensions. $\mathrm{L}=373-549 \mathrm{~lm}, \quad \mathrm{H}=262-346 \mathrm{~lm}, \quad \mathrm{H} / \mathrm{L}=0.63-$ 0.70 (Fig. 18). 
Remarks. Cyathus caperata is known throughout the entire Permian. We gathered all the available data and compared the size and morphology of the specimens in the Early, Middle and Late Permian (Fig. 18). They allowed us to reconstruct several ontogenetic stages: A-5 to Adult for Early Permian (Fig. 18A), A-2 to Adult for Middle Permian (Fig. 18B), A-4 to Adult for Late Permian (Fig. 18C). It therefore appears that all the Iranian specimens reported from the present analysis are A-2 juveniles. The ontogenetic development of this species mostly corresponds to an increase in dimensions. Similarly, no clear sexual dimorphism can be distinguished, for either the Lower or Middle Permian specimens. Among the Upper Permian fauna, some A-2 and A-1 specimens are relatively more elongated with more inflated PB (labelled 1 on Fig. 18C). These specimens might be females, but additional material is necessary to confirm this hypothesis.

Occurrence. Samples 03IR200, 202-204, Nesen Formation (Fig. 2; Forel et al. 2015, appendix 1), Elikah River section, Central Alborz, Iran, Changhsingian, Late Permian (this work). Chihsia Formation, Jurong and Longtan area, Jiangsu Province, China, Early Permian (Chen and Bao 1986). Wugang, Hunan Province, China, Early Permian (Guan et al. 1978). Saiwa section, Guizhou Province, China, Late Permian (Yuan et al. 2009). Meishan section, Zhejiang Province, China, Changhsingian, Late Permian (Shi and Chen 1987; Crasquin et al. 2010a). Sak Chai Quarry section, Chaiyaphum Province, Nong Phai section, Phetchabun Province, north-eastern Thailand, Early Permian, Ta Kli section, Nakhon Sawan Province, Middle Permian, central Thailand (Chitnarin et al. 2012). E-Lert Formation, Loei Province, northern Thailand (Burrett et al. 2014).

Cyathus elliptica Shi in Shi and Chen, 1987 Figure 17C, D

1987 Cyathus elliptica Shi in Shi and Chen, p. 32, pl. 10, figs 20-23; pl. 17, figs 5, 6.

2010a Cyathus elliptica; Crasquin et al., p. 334, fig. 3E-H.

2012 Cyathus elliptica; Chitnarin et al., p. 810, fig. 4E-H.

2014 Cyathus elliptica; Burrett et al., p. 16, fig. 12u-w.

Material. Four carapaces, several fragments.

Dimensions. See Figure 19.

\begin{tabular}{lll}
\hline & L $(\mathrm{lm})$ & H $(\mathrm{lm})$ \\
\hline & & $319-$ \\
Adult & $598-607$ & 369 \\
A-1 & $528-534$ & $265-$ \\
& & 299 \\
A-2 & $453-498$ & $239-$ \\
& & 284 \\
A-3 & $401-457$ & $306-$ \\
& & 347 \\
A-4 & $341-378$ & $182-$ \\
& & 212 \\
\hline
\end{tabular}

Remarks. Cyathus elliptica is known from the Early-Middle Permian of Thailand (Chitnarin et al. 2012) to the Late Permian of Meishan, China (Shi and Chen 1987; Crasquin et al. 2010a) and Iran (present work). The Lower and Middle Permian specimens are not abundant and are not used here. All the Upper Permian specimens gather into five ontogenetic groups, from A-4 to Adult, Iranian specimens belonging to A-4, A-1 and Adult stages (Fig. 19). From the stage A-3, two morphologies are distinguished. The specimens with relatively symmetrical $\mathrm{PB}$ and $\mathrm{AB}$, with an overall subrectangular contour, correspond to female morphs (labelled 1 on Fig. 19), while the specimens that are laterally thinner and more elongated with tapered PB are identified as males (labelled 2 on Fig. 19). The present data document the appearance of precocious sexual dimorphism in A-3 for Cyathus elliptica. 


\section{[Digitare qui]}

et al. 2010a). Sak Chai Quarry section, Chaiyaphum Province, Nong Phai section, Phetchabun Province, north-eastern Thailand, Early Permian, Ta Kli section, Nakhon Sawan Province, Middle Permian, central Thailand (Chitnarin et al. 2012). E-Lert Formation, Loei Province, northern Thailand (Burrett et al. 2014).

Suborder KIRKBYOCOPINA Grundel, $1969 €$

Superfamily KIRKBYOIDEA Ulrich and Bassler, 1906 Family KIRKBYIDAE Ulrich and Bassler, 1906

Genus KNIGHTINA Kellett, 1933

Type species. Amphissites allorismoides Knight, 1928.

Knightina bullaensis Crasquin in Crasquin et al., 2008

Figure $17 \mathrm{H}-\mathrm{J}$

2008 Knightina bullaensis Crasquin in Crasquin et al., p. 242, pl. 1, figs 16-17.

Material. 12 carapaces, several fragments.

Dimensions. See Figure 20.

\begin{tabular}{lll}
\hline & L $(\mathrm{lm})$ & H $(\mathrm{lm})$ \\
\hline Adult & 1232 & 585 \\
A-1 & 839 & 451 \\
A-2 & 733 & 344 \\
A-3 & $545-606$ & $281-$ \\
& & 304 \\
A-4 & $487-499$ & $239-$ \\
A-5 & & 267 \\
& $407-428$ & $194-$ \\
A-6 & & 220 \\
\hline
\end{tabular}



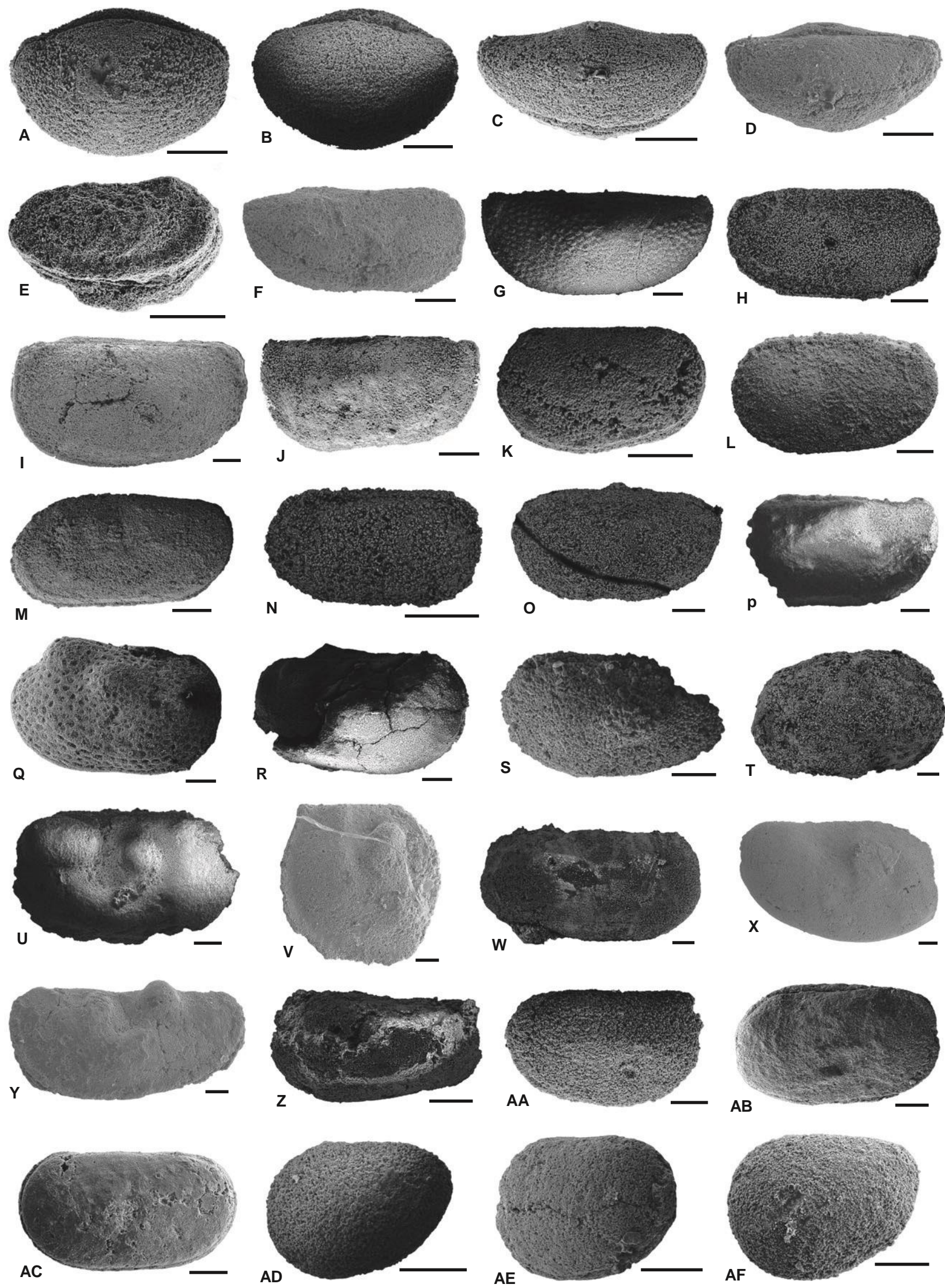
FIG. 17. Ostracods from the Elikah River section, Iran. All specimens are housed in the collections of Universite Pierre et Marie Curie, Paris, France. A-B, Cyathus caperata (Guan); A, carapace, left lateral view, P6M3525, sample 03IR203, Late Permian; B, carapace, left lateral view, P6M3526, sample 03IR203, Late Permian. C-D, Cyathus elliptica Shi; C, carapace, right lateral view, P6M3527, sample 03IR203, Late Permian; D, carapace, left lateral view, P6M3528, sample 03IR182, Late Permian. E, Carinaknightina cf. zhengfengensis Hao, 1992 of Yi 2004, carapace, right lateral view, P6M3529, sample 03IR203, Late Permian. F, Kirkbya sp. 1?, carapace, right lateral view, P6M3530, sample 03IR159, Late Permian. G, Kirkbya sp. 2, carapace, left lateral view, P6M3531, sample 03IR203, Late Permian. H-J, Knightina bullaensis Crasquin; H, carapace, right lateral view, P6M3532, sample 03IR216, Late Permian; I, carapace, left lateral view, P6M3533 sample 03IR171, Late Permian; J, carapace, left lateral view, P6M3534, sample 03IR185, Late Permian. K-M, Reviya cf. praecurukensis Forel in Forel et al., 2013b; K, carapace, left lateral view, P6M3535, sample 03IR172, Late Permian; L, carapace, left lateral view, P6M3536, sample 03IR172, Late Permian; M, carapace, left lateral view, P6M3537, sample 03IR172, Late Permian. N, Reviya? sp. 1, carapace, right lateral view, P6M3538, sample 03IR225, Early Triassic. O, Buekkella sp., carapace, left lateral view, P6M3539, sample 03IR220, Early Triassic. P, Polytylites? sp. 1, fragment of carapace, left lateral view, P6M3540, sample 03IR212, Late Permian. Q-R, Parahollinella visnyoensis Kozur, 1985; Q, carapace, right lateral view, P6M3541, sample 03IR201, Late Permian; R, carapace, right lateral view, P6M3542, sample 03IR203, Late Permian. S, Parahollinella? sp. 1, carapace, left lateral view, P6M3543, sample 03IR159, Late Permian. T, Roundyella? cf. papilliformis Wang, 1978, carapace, right lateral view, P6M3544, sample 03IR230, Early Triassic. U, Hollinella sp. 1, carapace, left lateral view, P6M3545, sample 03IR212, Late Permian. V, Hollinella sp. 2, carapace, right lateral view, P6M3546, sample 03IR193, Late Permian. W, Hollinella sp. 3, carapace, left lateral view, P6M3547, sample 03IR234, Early Triassic. X-Y, Hollinella sp. 4; X, carapace, right lateral view, P6M3548, sample 03IR163, Late Permian; Y, carapace, left lateral view, P6M3549, sample 03IR163, Late Permian. Z, Hollinellidae? indet., carapace, left lateral view, P6M3550, sample 03IR226, Early Triassic. AA, Langdaia? sp. 1, fragment of carapace, right lateral view, P6M3551, sample 03IR200, Late Permian. AB-AC, Indivisia sp. 1; AB, carapace, right lateral view, P6M3552, sample 03IR196, Late Permian; AC, carapace, right lateral view, P6M3553, sample 03IR201, Late Permian. AD-AF, Paraparchites chenshii Crasquin; AD, carapace, left lateral view, P6M3554, sample 03IR162, Late Permian; AE, carapace, left lateral view, P6M3555, sample 03IR162, Late Permian; AF, carapace, left lateral view, P6M3556, sample 03IR203, Late Permian. All scale bars represent 100 lm.



FIG. 18. Length/Height scatter plot of Cyathus caperata (Guan) in the Early (A), Middle (B) and Late Permian (C). All Lower and Middle Permian specimens are from Thailand (Chitnarin et al. 2012), and all Upper Permian specimens are from South China (Guizhou Province: Guan et al. 1978; Meishan GSSP, Zhejiang Province: Crasquin et al. 2010a) and Iran (this work). 1, female? 
Remarks. The specimens of Knightina bullaensis recovered from the present work and from the Bulla section, Italy (Crasquin et al. 2008), are distributed among seven ontogenetic stages, from A-6 to Adult (Fig. 20). The two Italian specimens are A-5 juveniles. Because of its tapered PB, the only known Adult specimen is identified as a male. The A-1 specimen displays a more rectangular shape and might therefore be a female.

Occurrence. Samples 03IR159, 161, 162, 171, 172, 185, 194, 202, 207, 216, Nesen and Elikah formations (Fig. 2; Forel et al. 2015, appendix 1), Elikah River section, Central Alborz, Iran, Changhsingian, Late Permian (this work). Bulla section, Dolomites, Italy, Changhsingian, Late Permian (Crasquin et al. 2008).

Family AMPHISSITIDAE Knight, 1928

Genus PARAHOLLINELLA Zalanyi, 1974 emend. Kozur, 1985

Type Species. Parahollinella hungarica Zalanyi, 1974.

Parahollinella visnyoensis Kozur, 1985

Figure 17Q, R

1985 Parahollinella visnyoensis Kozur, pp. 32-33, taf. 7, figs 8, 9.

1985 Kegelites visnyoensis; Kozur, p. 117.

2008 Parahollinella visnyoensis; Crasquin et al., pl. 2, fig. 4.

Material. Two complete carapaces, several fragments.

Dimensions. $\mathrm{L}=680-821 \mathrm{~lm}, \mathrm{H}=439-609 \mathrm{~lm}, \mathrm{H} / \mathrm{L}=0.65-0.74$.

Occurrence. Samples 03IR196, 201, 203, 213, Nesen Formation (Fig. 2; Forel et al. 2015, appendix 1), Elikah River section, Central Alborz, Iran, Changhsingian, Late Permian (this work). Bukk€ Mountains, Hungary, Wuchiapingian (Abadahian), Late Permian (Kozur 1985). Bulla section, Dolomites, Italy, Changhsingian, Late Permian (Crasquin et al. 2008).

Superfamily PARAPARCHITIDEA Scott, 1959 emend. Sohn, 1971

Family PARAPARCHITIDAE Scott, 1959

Genus PARAPARCHITES Ulrich and Bassler, 1906 emend. Scott, 1959

Type species. Paraparchites humerosus Ulrich and Bassler, 1906.

Paraparchites chenshii Crasquin in Crasquin et al., 2010a Figure 17AD-AF

1982

Paraparchites kansasensis; Chen and Shi, p. 116, pl. 3, figs 1-3.

1987 Paraparchites kansasensis; Shi and Chen, p. 34, pl. 11, figs 1-4.

2002 Paraparchites kansasensis; Shi and Chen, p. 62, pl. 1, figs 26-30.

2010a Paraparchites chenshii Crasquin in Crasquin et al., pp. 338-339, fig. 4M-S.

?2010b Paraparchites chenshii; Crasquin et al., p. 25, pl. 1, fig. 12. 


\section{[Digitare qui]}

2012 Paraparchites chenshii; Chitnarin et al., p. 816, fig. 8J-L.

Material. Seven complete carapaces, several fragments.

Dimensions. $\mathrm{L}=281-370 \mathrm{~lm}, \mathrm{H}=213-286 \mathrm{~lm}, \mathrm{H} / \mathrm{L}=0.68-0.79$ (Fig. 21).

Remarks. The species Paraparchites chenshii is known from the Early Permian (Chitnarin et al. 2012) to the Late Permian (Chen and Shi 1982; Shi and Chen 1987, 2002; Crasquin et al. 2010a; this work). The Middle Permian specimens are distributed among four successive stages, from A-3 to Adult. Only two specimens are known from the Early Permian and are identified as Adults (Fig. 21A). The Upper Permian specimens are distributed from A5 to Adult (Fig. 21B).

As stated by Crasquin et al. (2010a), modifications through the ontogeny of P. chenshii mostly affect the height and roundness of PB. All A-5 specimens are strongly asymmetrical with tapered PB. The differentiation of sexual morphs might begin in stage A-4, with some asymmetrical specimens (males, labelled 2 on Fig. 21), while others display a wider PB (females, labelled 1 on Fig. 21). This pattern of PB widening further develops in A-3 onwards. The present data could trace the expression of sexual dimorphism on the carapace of Paraparchites chenshii back to A-4. All A-4 specimens of Middle Permian age are male morphs with asymmetrical height and tapered PB. The only specimen attributed to A-2 also displays a male morphology. Stockier shape with enlarging of PB is only observed in A-1 and Adults (see Discussion).

Occurrence. Samples 03IR159, 162, 197, 203, Nesen Formation (Fig. 2; Forel et al. 2015, appendix 1), Elikah River section, Central Alborz, Iran, Changhsingian, Late Permian (this work). Pingding section, Guangxi Province, China, Wuchiapingian, Late Permian (Shi and Chen 2002). Wantong section, Hubei Province, South China, Changhsingian, Late Permian (Chen and Shi 1982). Meishan section, Zhejiang Province, South China, Changhsingian, Late Permian (Shi and Chen 1987; Crasquin et al. 2010a). 


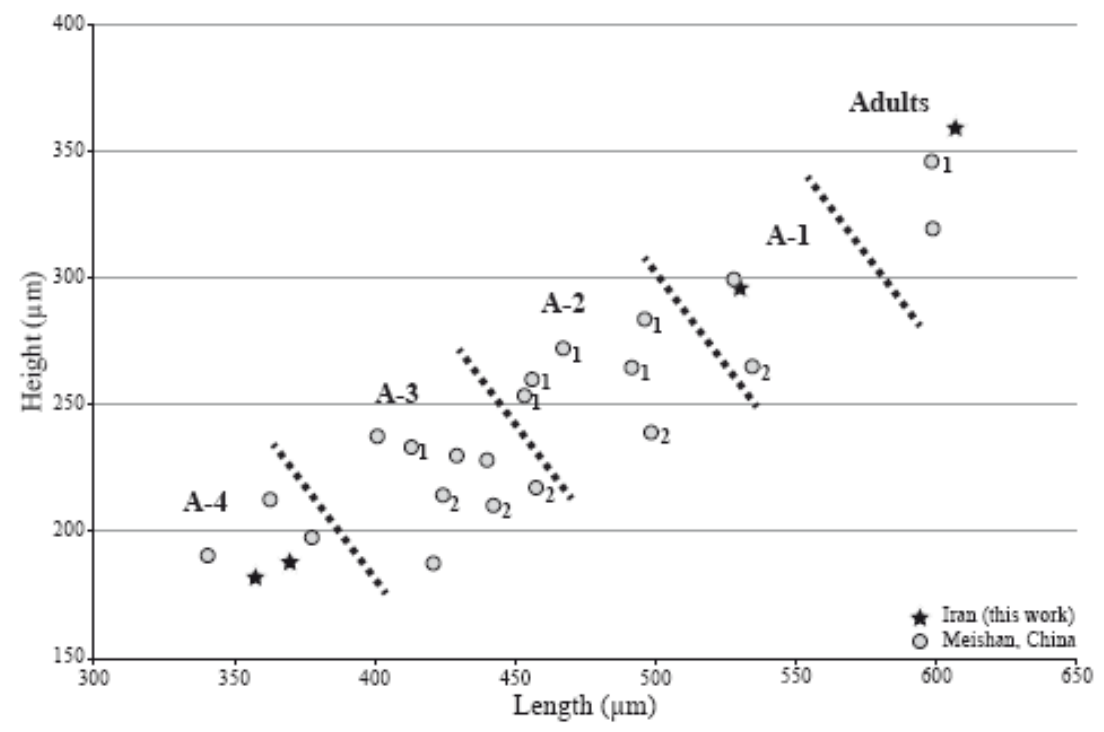

FIG. 19. Length/Height scatter plot of Cyathus elliptica Shi from the Late Permian of South China (Meishan GSSP, Zhejiang Province: Crasquin et al. 2010a) and Iran (this work); 1, female; 2, male 


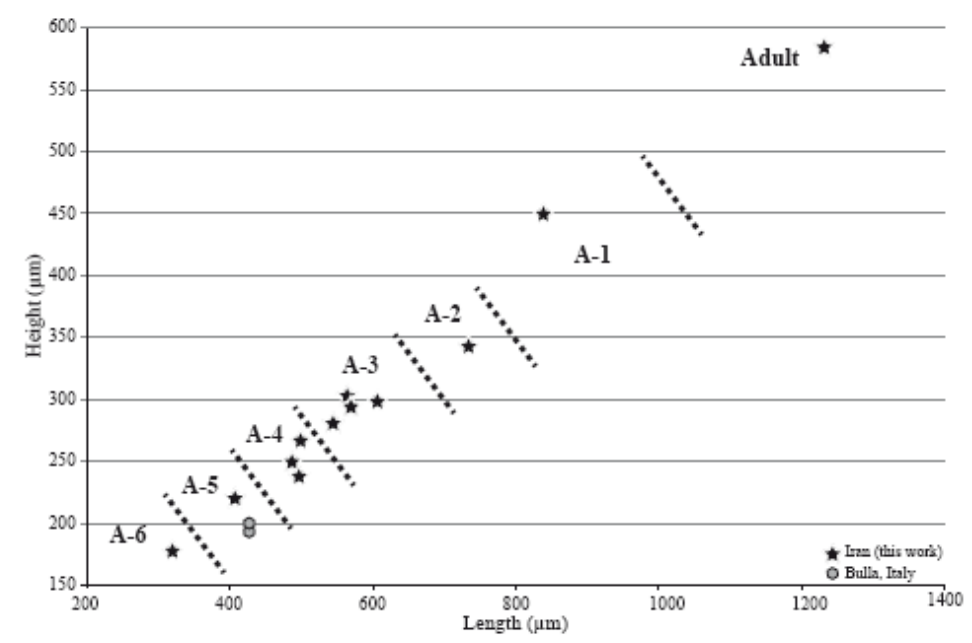

FIG. 20. Length/Height scatter plot of Knightina bullaensis Crasquin. All Lower and Middle Permian specimens are from Thailand (Chitnarin et al. 2012), and all Upper Permian specimens are from South China (Guizhou Province: Guan et al. 1978; Meishan GSSP, Zhejiang Province: Crasquin et al. 2010a) and Iran (this work).



FIG. 21. Length/Height scatter plot of Paraparchites chenshii Crasquin in the Early-Middle Permian (A) and Late Permian (B). All Lower and Middle Permian specimens are from Thailand (Chitnarin et al. 2012), and all Upper Permian specimens are from South China (Guangxi Province: Shi and Chen 2002; Meishan GSSP, Zhejiang Province: Crasquin et al. 2010a) and Iran (this work); 1, female; 2, male. 
Type species. Samarella crassa Polenova, 1952.

2010a Samarella victori Crasquin in Crasquin et al., p. 339, fig. $4 \mathrm{~T}-\mathrm{X}$.

Material. 19 complete carapaces, several fragments.

Dimensions. See Figure 23.

\begin{tabular}{lrl}
\hline & \multicolumn{1}{c}{ L $(\mathrm{lm})$} & $\mathrm{H}(\mathrm{lm})$ \\
\hline Adult & 954 & 754 \\
A-1 & 618 & 553 \\
A-2 & $504-581$ & $402-$ \\
& & 466 \\
A-3 & $414-553$ & $349-$ \\
& & 436 \\
A-4 & $324-338$ & $258-$ \\
& & 286 \\
\hline
\end{tabular}

Remarks. All the known specimens of Samarella victori Crasquin correspond to A-4 to Adult stages (Fig. 23). Differentiation of two morphs is recorded in A-3. The female morph displays an inflated PB, downward migration of the posterior maximum of curvature and migration of $\mathrm{H}_{\max }$ towards $\mathrm{AB}$, resulting in a relatively amplete shape (labelled 1 on Fig. 23). The male morph is relatively amplete with PB tapered and posterior maximum of convexity located in the upper fourth of $\mathrm{H}_{\max }$ (labelled 2 on Fig. 23). These distinct shapes further develop in A-2 stage. Females in A-2 display a higher carapace than males, generally located in the lower right hand portion of the scatter point. The only A1 specimen identified displays a female shape with further widening of $\mathrm{PB}$. This trend is accentuated in the unique adult of female gender displaying a subsymmetrical lenticular shape. The present data illustrate the appearance of precocious sexual dimorphism on the carapace of the Upper Permian Samarella victori in A-3 (see Discussion).

Occurrence. Samples 03IR162, 171, 172, 182, 197, 201-204, 206, 207, 213, Nesen Formation (Fig. 2; Forel et al. 2015, appendix 1), Elikah River section, Central Alborz, Iran, Changhsingian, Late Permian (this work). Meishan section, Zhejiang Province, South China, Changhsingian, Late Permian (Crasquin et al. 2010a).

Samarella meishanella Forel in Crasquin et al., 2010a

Figure 22F-H

1982 Paraparchites texanus; Chen and Shi, p. 117, pl. 3, figs 9-11.

1987 Paraparchites texanus; Shi and Chen, p. 35, pl. 11, figs 5-12.

2002 Paraparchites subrotundus; Shi and Chen, p. 62, pl. 1, figs 31-33.

2010a Samarella meishanella Forel in Crasquin et al., pp. 339-340, fig. 4Y-A'.

2013b Samarella meishanella; Forel et al., fig. 4, M-O.

Material. Four complete carapaces, several fragments. 
[Digitare qui]
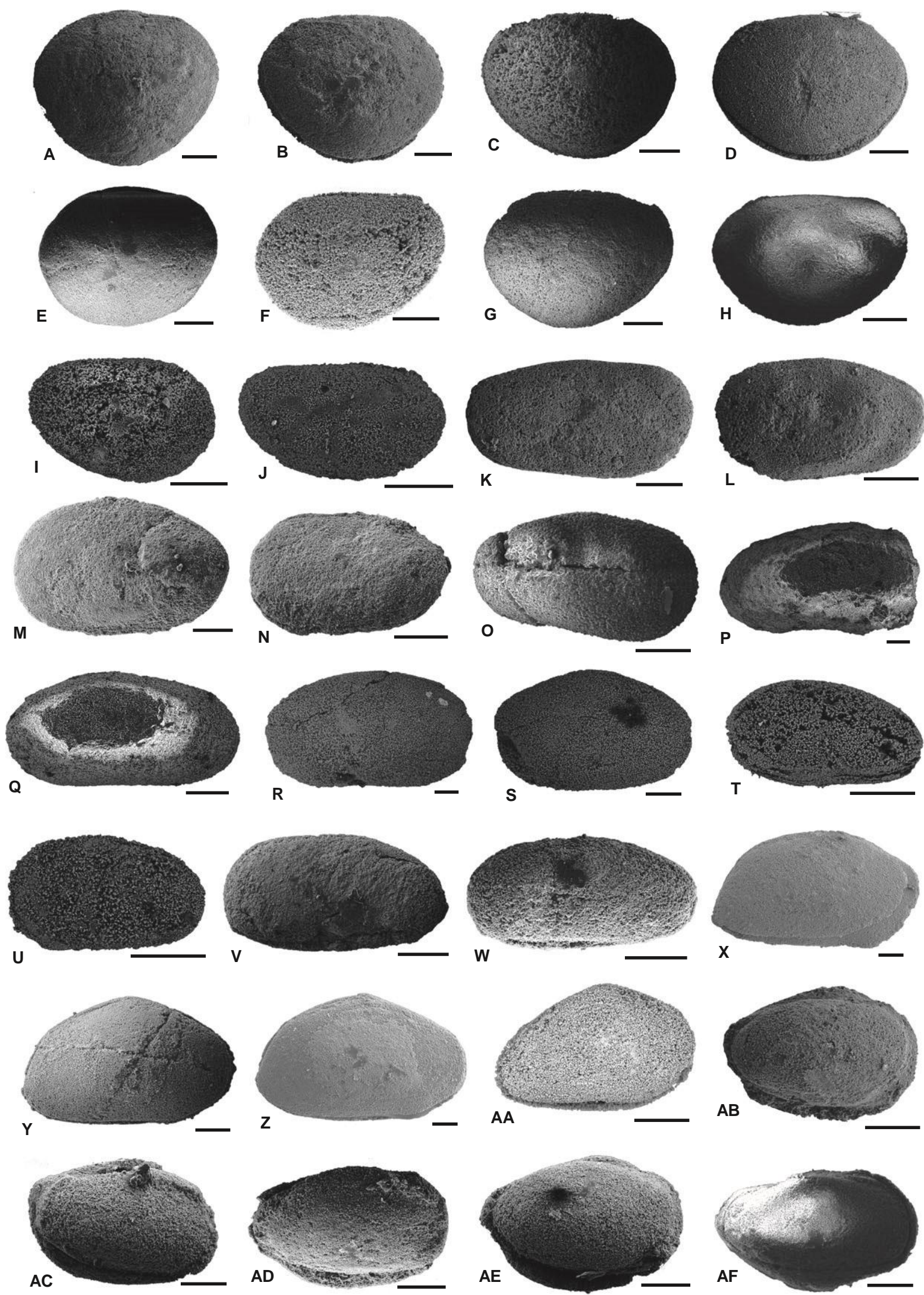

[Digitare qui] 
FIG. 22. Ostracods from the Elikah River section, Iran. All specimens are housed in the collections of Universite Pierre et Marie Curie, Paris, France. A-E, Samarella victori Crasquin; A, carapace, left lateral view, P6M3557, sample 03IR162, Late Permian; B, carapace, right lateral view, P6M3558, sample 03IR162, Late Permian; C, carapace, right lateral view, P6M3559, sample 03IR171, Late Permian; D, carapace, right lateral view, P6M3560, sample 03IR172, Late Permian; E, carapace, right lateral view, P6M3561, sample 03IR201, Late Permian. F-H, Samarella meishanella Forel; F, carapace, left lateral view, P6M3562, sample 03IR207, Late Permian; G, carapace, left lateral view, P6M3563, sample 03IR210, Late Permian; H, carapace, left lateral view, P6M3564, sample 03IR212, Late Permian. I-J, Shemonaella sp. 1; I, carapace, right lateral view, P6M3565, sample 03IR216, Late Permian; J, carapace, right lateral view, P6M3566, sample 03IR222, Early Triassic. K-O, Cavellina nesenensis Crasquin sp. nov.; K, holotype, carapace, left lateral view, P6M3567, sample 03IR172, Late Permian; L, carapace, left lateral view, P6M3568, sample 03IR172, Late Permian; M, carapace, left lateral view, P6M3569, sample 03IR200, Late Permian; N, carapace, left lateral view, P6M3570, sample 03IR213, age Late Permian; O, paratype, carapace, left lateral view, P6M3571, sample 03IR214, Late Permian. P-Q, Cavellina cf. suprapermiana Kozur, 1985; P, fragment of carapace, right lateral view, P6M3572, sample 03IR226, Early Triassic; Q, carapace, right lateral view, P6M3573, sample 03IR231, Early Triassic. R-S, Cavellina? sp. 1; R, carapace, right lateral view, P6M3575, sample 03IR239, Early Triassic; S, carapace, left lateral view, P6M3575, sample 03IR239, Early Triassic. T, Cytherellina sp. 1, carapace, left lateral view, P6M3576, sample 03IR223, Early Triassic. U, Healdianella cf. distincta Polenova, 1952, carapace, right lateral view, P6M3577, sample 03IR223, Early Triassic. V-W, Healdianella cf. subcuneola Posner, 1951; V, carapace, right lateral view, P6M3578, sample 03IR182, Late Permian; W, carapace, right lateral view, P6M3579, sample 03IR198, Late Permian. X-Z, Silenites? sasakwaformis Shi; X, carapace, right lateral view, P6M3580, sample 03IR161, Late Permian; Y, carapace, right lateral view P6M3581, sample 03IR203, Late Permian; Z, carapace, right lateral view, P6M3582, sample 03IR182, Late Permian. AA, Spinocypris? sp. 1, carapace, right lateral view, sample 03IR207, Late Permian, P6M3583. AB-AF, ?Eumiraculum desmaresae Forel; AB, carapace, right lateral view, P6M3582, sample 03IR162, Late Permian; AC, carapace, right lateral view, P6M3583, sample 03IR200, Late Permian; AD, carapace, right lateral view, P6M3584, sample 03IR202, Late Permian; AE, carapace, right lateral view, P6M3585, sample 03IR200, Late Permian; AF, carapace, right lateral view, P6M3586, sample 03IR203, Late Permian. All scale bars represent $100 \mathrm{~lm}$.

Dimensions. See Figure 24.

\begin{tabular}{lll}
\hline & $\mathrm{L}(\mu \mathrm{m})$ & $\mathrm{H}(\mu \mathrm{m})$ \\
\hline Adult & $534-574$ & $395-440$ \\
A-1 & $497-515$ & $372-403$ \\
A-2 & $462-482$ & $341-373$ \\
A-3 & $425-443$ & $297-348$ \\
A-4 & $375-402$ & $293-302$ \\
A-5 & $330-353$ & $240-249$ \\
\hline
\end{tabular}

Remarks. Although Samarella meishanella is observed to cross the PTB in Hungary (Forel et al. 2013b), it is only reported here from Upper Permian deposits. All specimens known from the Late Permian are distributed among six ontogenetic stages, A-5 to Adult (Fig. 24). The four Iranian specimens belong to A-4, A-3 and A-2, while the unique Permian specimen from Hungary is attributed to A-5. The two specimens attributed to A-5 correspond to the two different morphs typical of sexual dimorphism: PB is tapered at the Meishan specimen (male), while the carapace is subrectangular on the Hungarian specimen (female). Through the ontogeny, female morphs show a backward migration of $\mathrm{H}_{\max }$ : from subamplete in A-5, they become preplete. The attribution of the Triassic specimens, only known from Hungary, to an ontogenetic stage is complex. They all display a male shape and therefore represent either stages younger than A-5 or a taphonomic bias. Comparing the amplitude of their size distribution with the stages reconstructed from the Late Permian, it seems that they represent at least two different stages, here labelled A-x and A-(x-1).

Occurrence. Samples 03IR205, 210, 212, Nesen Formation (Fig. 2; Forel et al. 2015, appendix 1), Elikah River section, Central Alborz, Iran, Changhsingian, Late Permian (this work). Matan and Pingding sections, Guangxi Province, China, Wuchiapingian, Late Permian (Shi and Chen 2002). Mianyang section, Hubei Province, China, Changhsingian, Late Permian (Chen and Shi 1982). Meishan section, Zhejiang Province, China, Changhsingian, Late Permian (Shi and Chen 1987; Crasquin et al. 2010a). Balvany North section, Bukk Mountains, Hungary,€ Changhsingian-Griesbachian, Late Permian - Early Triassic (Forel et al. 2013b). 
FIG. 23. Length/Height scatter plot of Samarella victori Crasquin. All specimens are from South China (Meishan GSSP, Zhejiang Province: Crasquin et al. 2010a) and Iran (this work); 1, female; 2, male. Types. Holotype: one complete carapace (Fig. 22K), P6M3567, sample 03IR172; paratype: one complete carapace (Fig. 22O), P6M3571, sample 03IR214.
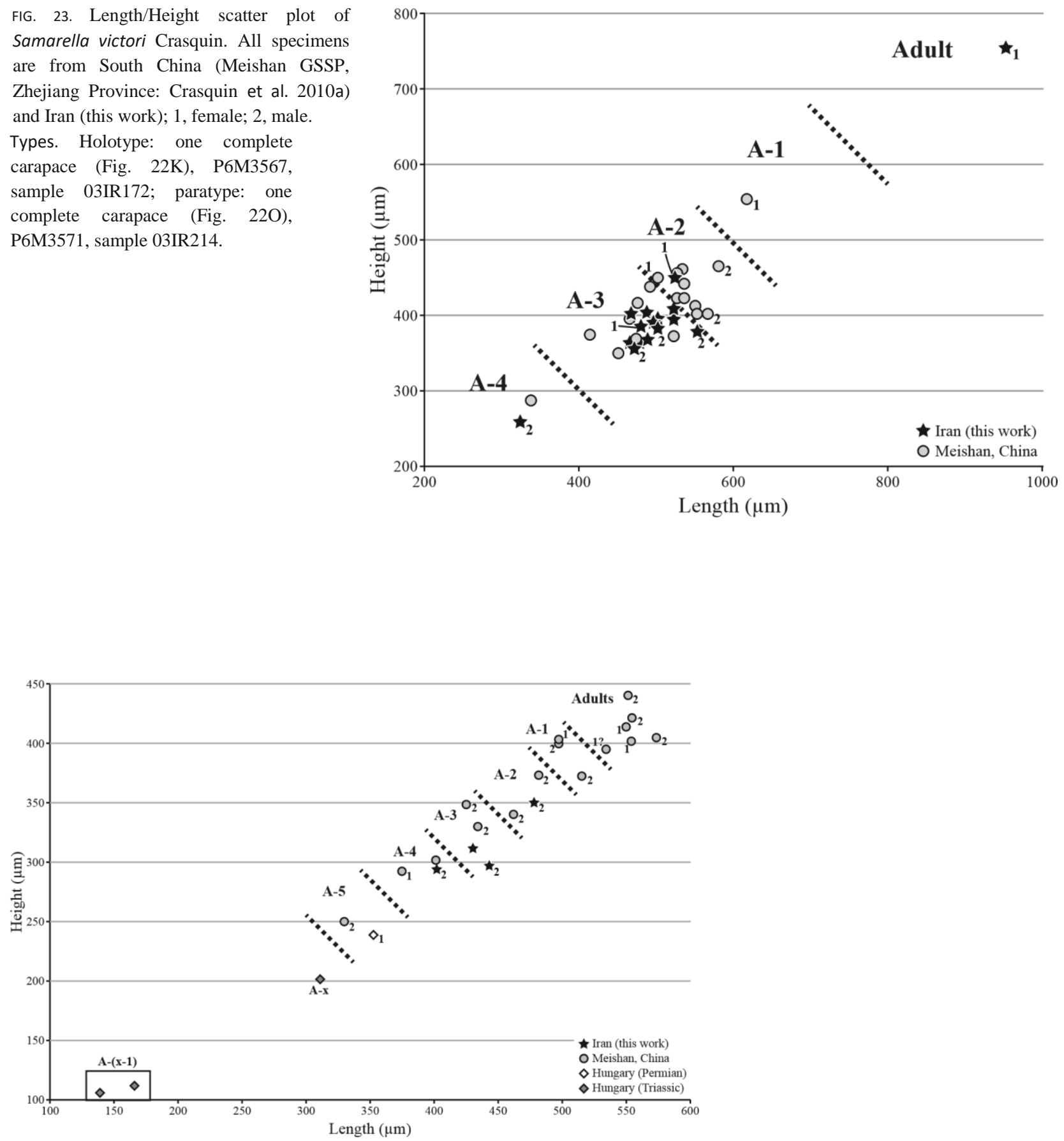

FIG. 24. Length/Height scatter plot of Samarella meishanella Forel. All specimens are from South China (Meishan GSSP, Zhejiang Province: Crasquin et al. 2010a), Hungary (Forel et al. 2013b) and Iran (this work); 1, female; 2, male. 
Order PLATYCOPIDA Sars, 1866

Suborder PLATYCOPINA Sars, 1866

Superfamily CAVELLINOIDEA Egorov, 1950

Family CAVELLINIDAE Egorov, 1950

Genus CAVELLINA Coryell, 1928

Type species. Cavellina pulchella Coryell, 1928.

Cavellina nesenensis Crasquin sp. nov. Figure $22 \mathrm{~K}-\mathrm{O}$

LSID. urn:Isid:zoobank.org:act:C642872E-1AF9-426A-A9D1-

70C39F96F256

Derivation of name. From the occurrence of the present species in the Nesen Formation.

Type horizon. Sample 03IR172, Elikah River section, Nesen Formation, Late Permian.

Type locality. Elikah River section (N 36 $13^{\circ} 27^{\prime \prime}$, E $51^{\circ} 20^{\circ} 48^{\prime \prime}$ ), Central Alborz, Iran.

Material. Five carapaces, several fragments.

Dimensions. $\mathrm{H}=173-197 \mathrm{~lm}, \quad \mathrm{~L}=295-340 \mathrm{~lm}, \quad \mathrm{H} / \mathrm{L}=0.52-0.62$ (Fig. 25).

Diagnosis. A species of Cavellina with an elongated carapace, AB narrower than PB and well expressed to faint $\mathrm{S}_{2}$.

Description. The carapace of the present species is elongate, subrectangular to sublenticular asymmetrical in lateral view, postplete with $\mathrm{H}_{\max }$ in the posterior third of $\mathrm{L}_{\max }$. A faint to well-expressed $\mathrm{S}_{2}$ is visible around mid- $\mathrm{L}_{\max }$, extending to mid- $\mathrm{H}_{\max }, \mathrm{L} 2$ and $\mathrm{L} 3$ relatively flat. A thin overlap of LV all around RV is visible at some specimens. The surface is smooth and outlines of RV and LV are very similar.

The PDB is about $50 \%$ of $\mathrm{L}_{\max }$ (Fig. 26), straight and bent towards PB with an angle up to 10; it forms an angle of 120 with PB. The DB is convex, more or less prominent and ngulated, and located around mid-Lmax. The ADB is straight; it is horizontal and continues the DB in some specimens, while it forms an angle around 90-120 with $\mathrm{AB}$ in some others. The $\mathrm{AB}$ is rounded to slightly angulate with a relatively narrow radius of curvature, whose maximum is located slightly above mid- $\mathrm{H}_{\max }$. The PB is broadly rounded with a large radius of convexity, the maximum being located around mid- $\mathrm{H}_{\max }$. The PVB is convex, short (15\% of $\mathrm{L}_{\max }$ ) and gently rose towards PB (100). The VB is straight to concave, long ( $60 \%$ of $\mathrm{L}_{\max }$ ) and forms an angle close to 10 with horizontal. The AVB is rounded, of middle length (25\% of $\mathrm{L}_{\max }$ ) and steeply bent towards $\mathrm{AB}\left(50^{\circ}\right)$. 

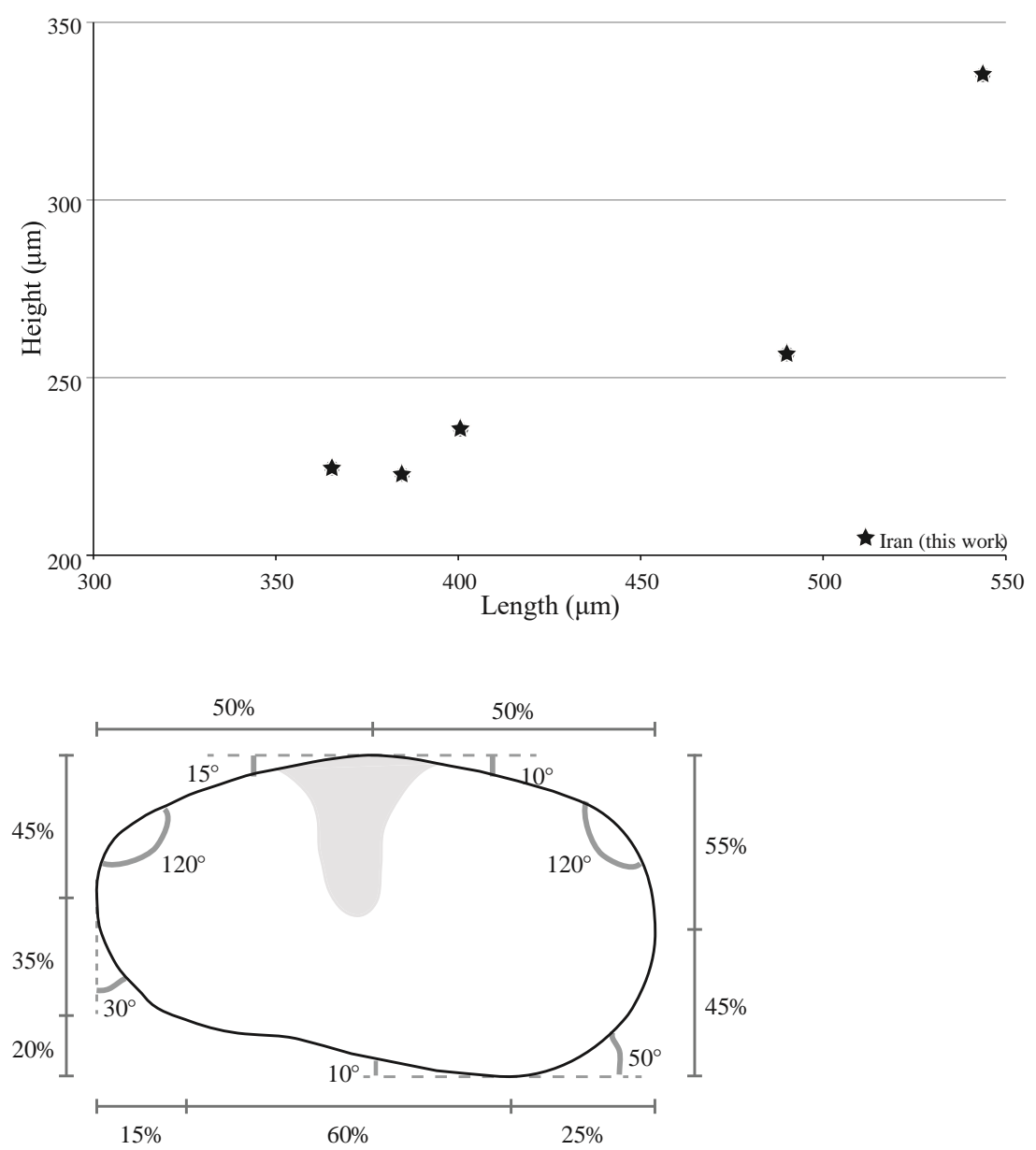

FIG. 25. Length/Height scatter plot of Cavellina nesenensis Crasquin sp. nov. All specimens are from Iran (this work).

FIG. 26. Scheme of the contour of a left valve of Cavellina nesenensis Crasquin sp. nov. showing all angles and proportions of the carapace.

Remarks. The new species described here differs from Cavellina jolfaensis from the Early Dzhulfian (Changhsingian) of northwest Iran (Mette 2010) by its longer ADB, larger radius of curvature at AB and PB. It is also different from C. aff. longa Kotchetkova and Guseva, 1972, from the early Dzhulfian of north-west Iran (Mette 2010) by its larger radius of curvature at PB. C. mocki Kozur, 1985 from the Abadehian (Wuchiapingian) of the Bukk€ Mountains, Hungary, is distinguished from the present species by its straighter DB with no angulation. C. nesenensis Crasquin sp. nov. differs from C. postunica Kozur, 1985 from the Abadehian of the Bukk Mountains, Hun- $€$ gary, by its more angulated DB and larger radius of curvature at AB. It is distinct from C. cf. rotunda Cooper, 1946, from the Late Permian of Meishan, South China (Shi and Chen 1987), by its different DB. It also differs from C. bellerophonella Crasquin from the Late Permian of the Bulla section (Italy; Crasquin et al. 2008) by its larger AB with a maximum of convexity located higher, $\mathrm{PB}$ broadly rounded and larger and thinner overlap. Internal structures of the present species have not been observed, and no trace of a septum of brood pouch is seen on the exterior of the valves. Among the Cavellina species known from the literature, sexual dimorphism is of domiciliar type and mostly visible in dorsal view. The largest specimen found here (Fig. 22M) displays a wider PB with a maximum of curvature located more ventrally than all the other specimens, possibly related to sexual dimorphism. However, no dorsal view is available here and specimens are not enough to determine the ontogenetic stages, and more material is needed to solve these issues.

Occurrence. Samples 03IR172, 200, 213, 214, Nesen Formation (Fig. 2; Forel et al. 2015, appendix 1), Elikah River section, Central Alborz, Iran, Changhsingian, Late Permian (this work). 


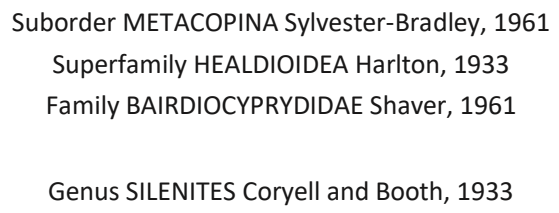

Type species. Silenites silenus Coryell and Booth, 1933.

Silenites? sasakwaformis Shi in Shi and Chen, 1987 Figure 22X-Z

1987 Silenites sasakwaformis Shi in Shi and Chen, p. 63, pl. 15, figs 22-25.

2010a Silenites? sasakwaformis; Crasquin et al., p. 358 , fig. $20 \mathrm{~A}^{0}-\mathrm{C}^{0}$.

Material. Five carapaces, several fragments.

Dimensions. See Figure 27.

\begin{tabular}{lll}
\hline & L $(\mathrm{lm})$ & H $(\mathrm{lm})$ \\
\hline \multirow{2}{*}{ Adult } & & \\
A-1 & $768-787$ & $463-$ \\
& $693-718$ & 497 \\
A-2 & & $375-$ \\
& $575-609$ & 422 \\
A-3 & & $271-$ \\
& $461-498$ & 399 \\
A-4 & & $261-$ \\
& $310-349$ & 278 \\
& & $186-$ \\
\hline
\end{tabular}

Remarks. All the known specimens of Silenites? sasakwaformis correspond to A-4 to Adult ontogenetic stages (Fig. 27). The specimens from the Elikah River section belong to A-4, A-2 and A-1. The shape of the present species is very conservative through the ontogeny. The Chinese specimens are very similar to the holotype described by Shi and Chen (1987) with carapace amplete, relatively elongate, PB close to vertical. Although intermediate morphologies make no doubt about the attribution of the Iranian specimens to S.? sasakwaformis, they document strong intraspecific variations in being higher, H/L less restricted, carapace less amplete and posterior with a maximum of convexity located higher.

Occurrence. Samples 03IR161, 182, 200, 203, Nesen Formation (Fig. 2; Forel et al. 2015, appendix 1), Elikah River section, Central Alborz, Iran, Changhsingian, Late Permian (this work). Meishan section, Zhejiang Province, China, Changhsingian, Late Permian (Shi and Chen 1987; Crasquin et al. 2010a). 
FIG. 27. Length/Height scatter plot of Silenites? sasakwaformis Shi. All specimens are from South China (Meishan GSSP, Zhejiang Province: Shi and Chen 1987; Crasquin et al. 2010a) and Iran (this work).



Order and suborder indet.

Genus EUMIRACULUM Chen in Shi and Chen, 1987

Type species. Eumiraculum changxingensis Chen in Shi and Chen, 1987.

?Eumiraculum desmaresae Forel in Forel et al., 2013b Figure 22AB-AF

?2013b Eumiraculum desmaresae Forel in Forel et al.,

p. 211, figs 18I-L, 19.

Material. Eight carapaces, several fragments.

Dimensions. $\mathrm{L}=350-445 \mathrm{~lm}, \quad \mathrm{H}=244-274 \mathrm{~lm}, \quad \mathrm{H} / \mathrm{L}=0.61-$

0.7 .

Remarks. We cast doubt on the attribution of the present species to the species Eumiraculum desmaresae Forel, 2013b because of the overall poor preservation of the specimens, all being smaller than those described from the type locality.

Occurrence. Samples 03IR162, 163, 200, 202, 203, 212, 213, Nesen Formation (Fig. 2; Forel et al. 2015, appendix 1), Elikah River section, Central Alborz, Iran, Changhsingian, Late Permian (this work). 


\section{SIZE CHANGE THROUGH TIME}

The Elikah River section provides interesting material to analyse both the size trends through the PTB (Basslerella superarella, Bairdia wailiensis) and during the overall Permian thanks to species in common with the Early and Middle Permian of Thailand (Cyathus caperata, Paraparchites chenshii). For each of these four species, distinct H/L diagrams were built for Permian and Triassic specimens.

The Lmin, Lmean, Lmax and Hmin, Hmean, Hmax of each successive ontogenetic stage were compared and used to calculate growth rates for both $\mathrm{L}$ and $\mathrm{H}$ as follows:

$$
\begin{aligned}
& \mathrm{K}_{\mathrm{H}} \frac{1}{4} \mathrm{H}_{\mathrm{np} 1}=\mathrm{H}_{\mathrm{n}} \\
& \mathrm{K}_{\mathrm{L}} \frac{1}{1} \mathrm{~L} \mathrm{Ln}_{\mathrm{n} 1}=\mathrm{Ln}
\end{aligned}
$$

where $\mathrm{K}_{\mathrm{H}}$ and $\mathrm{K}_{\mathrm{L}}$ are, respectively, $\mathrm{H}_{\text {mean }}$ and $\mathrm{L}_{\text {mean }}$ growth rates; $\mathrm{H}_{\mathrm{n}}$ and $\mathrm{L}_{\mathrm{n}}$ are, respectively, $\mathrm{H}_{\text {mean }}$ and $\mathrm{L}_{\text {mean }}$ at ontogenetic stage $\mathrm{n}$; and $\mathrm{H}_{n+1}$ and $\mathrm{L}_{n+1}$ are, respectively, $\mathrm{H}_{\text {mean }}$ and $\mathrm{L}_{\text {mean }}$ at ontogenetic stage $\mathrm{n}+1$. The reconstructed successive growth rates are then compared to the Brooks' rule generalizing the growth of ostracods to 1.26 (Brooks 1886; Teissier 1960).

\section{Short-term pattern through the PTB: the Lilliput effect}

Although several species are here found to cross the PTB, the analysis is complicated because of the low abundance of Permian assemblages compared to those of Early Triassic age. Only Basslerella superarella yielded enough specimens to perform such an analysis (Fig. 11U-Z). Thanks to its relatively widespread geographical distribution, the dimensions of Bairdia wailiensis (Fig. 3C-G) are compared through the PT transition in the Elikah River section (this work), Hungary (Forel et al. 2013b) and China (Guangxi Province; Crasquin-Soleau et al. 2006a).

\section{Basslerella superarella and its Lilliput effect in the Elikah River section.}

Among the 97 Basslerella superarella specimens recovered from the Elikah River section, 76 are suitable for size analysis: 66 of Permian and 10 of Triassic age. Six stages are recognized among the Permian specimens, from A-5 to Adult, and four for the Triassic specimens, from A-3 to Adult (Fig. 15). $\mathrm{L}_{\text {min }}, \mathrm{L}_{\text {mean }}, \mathrm{L}_{\max }$ and $\mathrm{H}_{\text {min }}, \mathrm{H}_{\text {mean }}, \mathrm{H}_{\max }$ have been determined and plotted for each ontogenetic stage recognized in the Late Permian and Early Triassic (Fig. 28A). For each stage, the percentages of size change from the Late Permian to the Early Triassic are summarized in Table 1. This quantification of size fluctuation through the PTB was only performed on stages A-3 to Adult since A-4 and A-5 are only known from Permian material. It appears that throughout most of the ontogeny, Permian specimens are strictly larger than their Triassic counterparts: the reduction in size ranges from $11.5 \%\left(\mathrm{~L}_{\min } \mathrm{A}-1\right)$ to $34.7 \%\left(\mathrm{H}_{\max } \mathrm{A}-1\right)$. For all stages, $\mathrm{H}$ displays stronger decrease than $\mathrm{L}$ and maximum size decreases more than mean, itself decreasing more than minimum.

These data are the first record of the Lilliput effect for ostracods through the PTB. Recently, slow growth and a 'bet-hedging' strategy by the increase in the fecundity with the production of smaller but more abundant eggs have been documented for several Podocopida from the Early Triassic of Turkey. A single species of Palaeocopida shows an accelerated growth, possibly linked to the production of fewer, bigger eggs (Forel 2014). $\mathrm{K}_{\mathrm{L}}$ and $\mathrm{K}_{\mathrm{H}}$ of Late Permian specimens are relatively stable throughout the ontogeny, with a slight acceleration reaching the Adult stage. Interestingly, all these Upper Permian values range from 1.11 ( $\mathrm{K}_{\mathrm{L}} \mathrm{A}-2$ to A-1) to 1.18 ( $\mathrm{K}_{\mathrm{L}} \mathrm{A}-1$ to Adult), lower than the Brooks' rule (Fig. 28A). The Upper Permian specimens of Basslerella superarella from the Elikah River section also record a slow growth pattern, that is paedomorphosis by deceleration, similar to those observed in Turkey (Forel 2014). This conclusion confirms a previously raised problem: the end-Permian extinction is generally considered independent from the end-Guadalupian event, and Upper Permian faunas are taken to represent a 'healthy' standard to study the following survival and recovery. However, the present record clearly highlights the abnormal ontogenetic rhythm experienced by some ostracods in relation to environmental perturbations already in the Late Permian. These latest Permian ostracods can no longer be considered as stable and wholesome since they are recovering from the Guadalupian-Lopingian events.

The Lower Triassic specimens display a strongly unstable growth rhythm, for both $\mathrm{L}$ and $\mathrm{H}$. Except for $\mathrm{K}_{\mathrm{L}}$ from A-3 to A2 and A-1 to Adult, all Triassic $K_{L}$ and $K_{H}$ are higher than Permian ones, ranging from $1.1\left(K_{L} A-3\right.$ to A-2) to 1.32 (KH $A-1$ to Adult). The acceleration of $K_{H}$ towards Adult might indicate that Adult was the most resilient stage for this species. However, 
$\mathrm{K}_{\mathrm{L}}$ at the A-1 to Adult transition simultaneously shows deceleration. In spite of their fluctuations, $\mathrm{K}_{\mathrm{L}}$ and $\mathrm{K}_{\mathrm{H}}$ of Basslerella superarella in the Early Triassic are lower than for their Upper Permian counterparts, respectively, 1.26 and 1.25 in Late Permian, 1.13 and 1.19 in Early Triassic, documenting the further reduction in growth through the PTB.

The large-scale Lilliput effect of Bairdia wailiensis.

The specimens of Bairdia wailiensis recovered from the Permian deposits of the Elikah (this work), the Triassic of China (Guangxi, Crasquin-Soleau et al. 2006a) and the Permian-Triassic of Hungary (Forel et al. 2013b) also document an interesting size pattern through the PTB on a large geographical scale. Among the 36 specimens known, 19 are of Late Permian age (Iran, this work and Hungary, Forel et al. 2013b) and 17 are of Early Triassic age (Guangxi, China, Crasquin-Soleau et al. 2006a and Hungary, Forel et al. 2013b). All specimens are distributed among five ontogenetic stages from A-4 to Adult (Fig. 4).


FIG. 28. Size changes of Basslerella superarella and Bairdia wailiensis through the PTB. A, Basslerella superarella at the Elikah River section, Iran (this work); length (bottom) and height (top) distributions of all Upper Permian (light grey) and Lower Triassic (dark grey) specimens from A-5 to Adult stage; length and height growth rates ( $\mathrm{K}_{\mathrm{L}}$ and $\mathrm{K}_{\mathrm{H}}$, respectively) are plotted at the transition between each developmental stage. B, Bairdia wailiensis in Guangxi, South China (Crasquin-Soleau et al. 2006a), Hungary (Forel et al. 2013b) and Iran (this work); length (bottom) and height (top) distributions of all Upper Permian (light grey) and Lower Triassic (dark grey) specimens from A-4 to Adult stage; Upper Permian growth rates were calculated from Iran specimens (this work) and Lower Triassic ones from Hungarian specimens. 
TABLE 1. Proportion of change of $\mathrm{L}_{\min }, \mathrm{L}_{\operatorname{mean}}, \mathrm{L}_{\max }$ and $\mathrm{H}_{\min }, \mathrm{H}_{\operatorname{mean}}, \mathrm{H}_{\max }$ calculated for the successive ontogenetic stages of Basslerella superarella (Iran, this work) and Bairdia wailiensis (South China: Crasquin-Soleau et al. 2006a; Hungary: Forel et al. 2013b; Iran: this work) from the Late Permian to the Early Triassic at the Elikah River section.

\begin{tabular}{|c|c|c|c|c|c|c|}
\hline & $L_{\min }$ & Lmean & $L_{\max }$ & $H_{\min }$ & $H_{\text {mean }}$ & $H_{\max }$ \\
\hline \multicolumn{7}{|c|}{ Basslerella superarella (\%) } \\
\hline \multicolumn{3}{|c|}{ Adult 1419} & & & & 25.5 \\
\hline A-1 & \multicolumn{2}{|c|}{11.514 .5} & 23.518 & 16.521 & 21.529 & 35 \\
\hline A-2 & \multicolumn{2}{|c|}{16.520 .5} & 23.5 & 23 & 28.5 & 33.5 \\
\hline A-3 & \multicolumn{2}{|c|}{1717.5} & 18.5 & 28.5 & 30.5 & 33 \\
\hline \multicolumn{7}{|c|}{ Bairdia wailiensis (\%) } \\
\hline Adult & 33.5 & 35.5 & 37.5 & 37.5 & 41.5 & 44.5 \\
\hline \multirow{3}{*}{$\begin{array}{l}\text { A-1 A- } \\
2 \\
\text { A-3 }\end{array}$} & 41.544 & 40 & 32 & 38 & 38 & 37 \\
\hline & \multirow[t]{2}{*}{48} & \multirow[t]{2}{*}{42.550} & \multirow[t]{2}{*}{4051} & 40 & 42 & 41.5 \\
\hline & & & & 49.5 & 47.5 & 48 \\
\hline A-4 & 28 & 40 & 45 & 32 & 41.5 & 46 \\
\hline
\end{tabular}

The Lmin, Lmean, Lmax and Hmin, Hmean, Hmax of all stages are summarized in Table 1 and Figure 28B. Throughout their entire ontogeny, the Lower Triassic specimens are significantly smaller than their Upper Permian counterparts with no overlap. Interestingly, this reduction in size is much stronger than in Basslerella superarella, ranging from $28 \%$ ( $\left.\mathrm{L}_{\text {min }} \mathrm{A}-4\right)$ to $51 \%$ ( $\mathrm{L}_{\text {max }} \mathrm{A}$ 3). Bairdia wailiensis shows that the size reduction observed in Basslerella superarella through the PTB at the Elikah River section is not a local pattern but is indeed worldwide since Hungarian and Chinese localities display similar characteristics. $\mathrm{K}_{\mathrm{L}}$ and $\mathrm{K}_{\mathrm{H}}$ have been calculated for the Upper Permian specimens from the Elikah River section (A-4 to A-2) and the Early Triassic of Hungary (A4 to Adult; Fig. 28B). Although only three stages have been found from the Permian of Iran, they document fast growth in L and $\mathrm{H}$ from A-4 to A-3, followed by a vertiginous drop down from A-3 to A-2. This pattern is hardly understandable and more specimens would assess this issue. Conversely, the Triassic $\mathrm{K}_{\mathrm{H}}$ is always lower than in Brooks' rule, decreasing from A-1 to Adult stage. The overall $\mathrm{K}_{\mathrm{L}}$ values increase from A-4 to A-1, the transition from A-2 to A-1 being the unique above Brooks' value. It then sharply decreases below Brooks' value to reach Adult size. Based on this Triassic pattern, A-1 might have been the most resilient stage for Basslerella superarella. Although the Permian ontogenetic rhythm remains obscure, the slow growth documented by the Triassic specimens corresponds again to paedomorphosis by deceleration.

The Lilliput effect is here documented for the first time for two ostracod species crossing the PTB. All the ontogenetic stages are affected by this size reduction, ranging from $11 \%$ (Basslerella superarella) to $51 \%$ (Bairdia wailiensis). It is accompanied by the onset of unstable and low growth rates in the Early Triassic.

\section{Long-term pattern through the Permian}

Three Palaeocopid species found from the present section are also known from the Early and Middle Permian of other localities (Thailand; Chitnarin et al. 2012; Cyathus caperata, C. elliptica, Paraparchites chenshii), two of them allow insights into their evolution throughout the Permian.

Cyathus caperata. As described previously, six, three and four ontogenetic stages are recognized among the Cyathus caperata, respectively, in the Early, Middle and Late Permian (Fig. 18). Lmin, Lmean, Lmax and Hmin, Hmean, Hmax of all stages in the Early, 
Middle and Late Permian are summarized in Figure 29A. From the Early to the Middle Permian, all dimensions decrease, ranging from $17 \%$

( $\mathrm{L}_{\min }, \mathrm{L}_{\text {mean }}$ Adult) to $34.5 \%\left(\mathrm{H}_{\min } \mathrm{A}-2\right.$; Table 2). From the Middle to the Late Permian, $\mathrm{L}$ and $\mathrm{H}$ patterns are dissociated: (1) $\mathrm{L}_{\text {min }}$ and $\mathrm{L}_{\text {mean }}$ diminish from $0.5 \%$ ( $\mathrm{L}_{\text {mean }}$ Adult) to $24 \%$ ( $\left.\mathrm{L}_{\min } \mathrm{A}-1\right)$, while $\mathrm{L}_{\max }$ stays relatively stable; and (2) all $\mathrm{H}$ increase strongly from A-2 to Adult from $1.5 \%\left(\mathrm{H}_{\min } \mathrm{A}-2\right)$ to $44.5 \%\left(\mathrm{H}_{\max }\right.$ Adult), overpassing the Middle Permian dimensions for $\mathrm{H}_{\max }$ A-1 and all the $\mathrm{H}$ of Adult, $\mathrm{H}_{\max }$ of Adult overpassing the Early Permian values. The Middle-Upper Permian transition is also characterized by an increase in the amplitude of size variations between

$\mathrm{L}_{\min }-\mathrm{L}_{\max }$ and $\mathrm{H}_{\min }-\mathrm{H}_{\max }$. Considering the overall Permian, all the $\mathrm{H}$ and $\mathrm{L}$ decrease, ranging from $17 \%\left(\mathrm{H}_{\max } \mathrm{A}-1\right)$ to $56 \%\left(\mathrm{~L}_{\min } \mathrm{A}-\right.$ 4), with the exception of $\mathrm{H}_{\max }$ at the Adult stage, increasing of $12 \% . \mathrm{K}_{\mathrm{H}}$ and $\mathrm{K}_{\mathrm{L}}$ were also calculated and compared, and in the Late Permian, only the Meishan data could be used (Fig. 29A). First, all the values of $\mathrm{K}_{\mathrm{H}}$ and $\mathrm{K}_{\mathrm{L}}$ are below Brooks' rule, except $\mathrm{K}_{\mathrm{H}}$ for the A-1 to Adult transition. It confirms that the Upper Permian faunas should not be taken as references to estimate the pre-PTB normal levels of biodiversity. For Cyathus caperata, this trend began at the Early-Middle Permian transition and destabilized at the transition with the Late Permian, with a strong increase in the dimensions of the last ontogenetic stages. Very interestingly, the general patterns show an increase in both $\mathrm{K}_{\mathrm{H}}$ and $\mathrm{K}_{\mathrm{L}}$ throughout the Permian. This observed reduction in size followed by a stagnation and relative increase in the last ontogenetic instars is therefore here associated with an overall acceleration of the growth during the entire Permian. Until now, such patterns have not been reported. Possible causes will be discussed below, but the strong and unprecedented decrease of size recorded between the Early and Middle Permian remains unexplained. A possible consideration is that Cyathus caperata belongs to the Palaeocopida, suffering greatly during the end-Permian extinction and disappearing at the base of the Triassic (with possible persistence of two living species in the Southern Pacific; see Crasquin and Forel 2014 for review). This pattern might correspond to an evolutive trend reflecting a degeneration of the Palaeocopida, as a possible mechanism of their extinction after the end-Permian crisis. The extinction rates of the ostracods through the end-Guadalupian event(s) are still poorly documented, and additional data might be helpful to understand why Palaeocopida survived the Guadalupian-Lopingian event(s) but disappeared after the end Permian main extinction. This issue is further discussed below in the light of the modifications in sexual precocity through time.

Paraparchites chenshii. As described previously, one, five and six ontogenetic stages are recognized, respectively, for the Lower, Middle and Upper Permian representatives of the species Paraparchites chenshii (Fig. 21). The $\mathrm{L}_{\text {min }}$,

Lmean, Lmax and Hmin, Hmean, Hmax of all stages are summarized in Figure 29B. From the Early to the Middle Permian, only the Adult stage can be analysed: $\mathrm{L}$ is relatively unchanged between $0.8 \%\left(\mathrm{~L}_{\max }\right)$ and $0.8 \%\left(\mathrm{~L}_{\min }\right)$, while $\mathrm{H}$ shows a homogeneous increase of about 9\% (Table 2). The Middle Permian specimens of A-4 to A-1 are all larger than their Upper Permian counterparts in all $\mathrm{H}$ and $\mathrm{L}$, documenting a decrease in size ranging from 5.5\% $\left(\mathrm{H}_{\max } \mathrm{A}-2\right)$ to $27 \%\left(\mathrm{~L}_{\min } \mathrm{A}-4\right)$. The transition to Adult stage is marked by the reversal of this pattern, Upper Permian specimens becoming larger for all $\mathrm{H}$ and $\mathrm{L}$, documenting an increase of $4 \%$ ( $\mathrm{L}_{\text {mean }}$ Adult) to $15.5 \%\left(\mathrm{H}_{\max }\right.$ Adult). These trends are underpinned by variable growth rates, alternating between values below and above Brooks' rule (Fig. 29B). The only Lower Permian $\mathrm{K}_{\mathrm{H}}$ and $\mathrm{K}_{\mathrm{L}}$ reconstructed here, from A-5 to A-4, are located slightly below the Brooks' rule. 
(A)
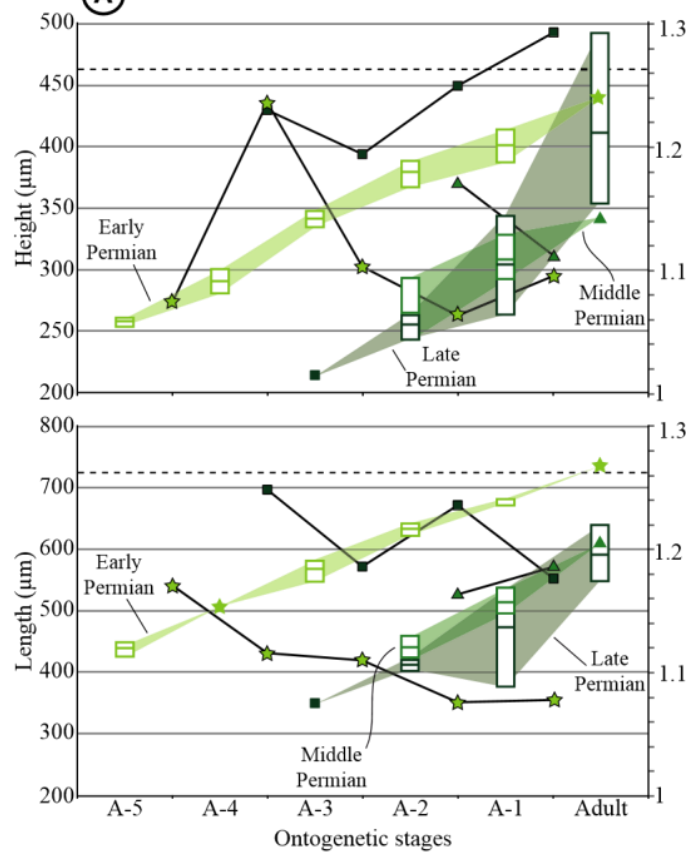

Growth rates:

$\rightarrow$ Late Permian

Early Permian

Early Permian
(B)
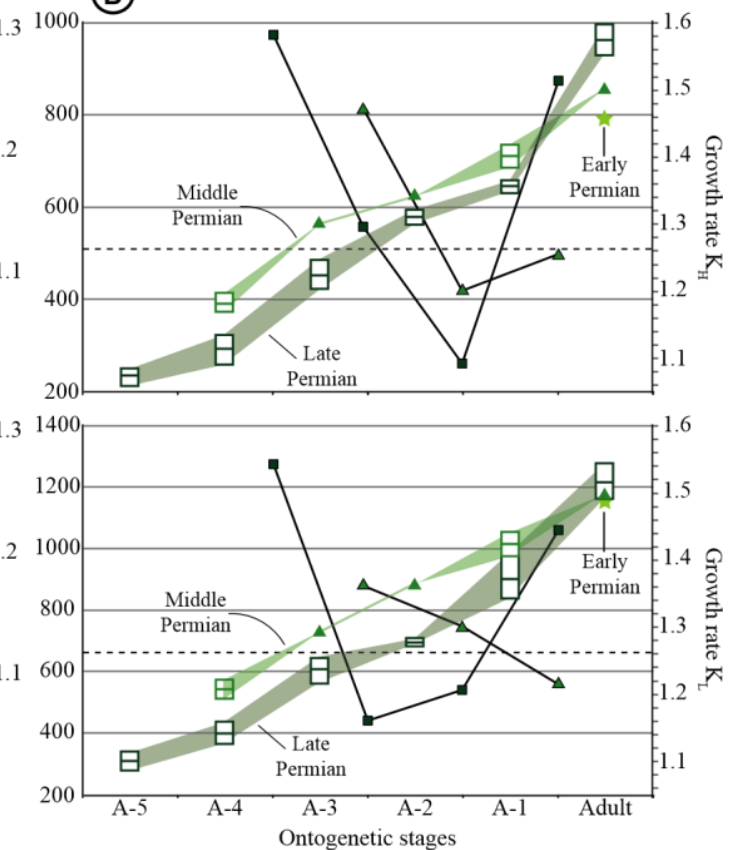

FIG. 29. Size changes of Cyathus caperata (Guan) and Paraparchites chenshii Crasquin through the Permian. A, Cyathus caperata from the Early-Middle Permian of Thailand (Chitnarin et al. 2012) and Late Permian of South China (Guizhou: Guan et al., 1978; Meishan GSSP, Zhejiang: Crasquin et al. 2010a) and Iran (this work; H/L scatter plot in Fig. 13); length (bottom) and height (top) distributions of all Lower (light shade), Middle (middle shade) and Upper Permian (dark shade) specimens for the reconstructed ontogenies; length and height growth rates $\left(\mathrm{K}_{\mathrm{L}}\right.$ and $\mathrm{K}_{\mathrm{H}}$, respectively) are plotted at the transition between each developmental stage and were calculated from Thailand specimens for the Early and Middle Permian (Chitnarin et al. 2012) and from Meishan, China, for the Late Permian (Crasquin et al. 2010a). B, Paraparchites chenshii from the Early-Middle Permian of Thailand (Chitnarin et al. 2012) and the Late Permian of South China (Guangxi: Shi and Chen 2002; Meishan, Zhejiang: Crasquin et al. 2010a) and Iran (this work; H/L scatter plot in Fig. 21); length (bottom) and height (top) distributions of all Lower (light shade), Middle (middle shade) and Upper Permian (dark shade) specimens for the reconstructed development stages; $\mathrm{K}_{\mathrm{L}}$ and $\mathrm{K}_{\mathrm{H}}$ were calculated from Thailand specimens for the Early and Middle Permian (Chitnarin et al. 2012) and from the Late Permian of Meishan, South China (Crasquin et al. 2010a). Colour online.

2010a).

In Middle Permian, $\mathrm{K}_{\mathrm{L}}$ decreases from A-3 to Adult, to reach values below Brooks' standard. In the mean time, $\mathrm{K}_{\mathrm{H}}$ strongly decreases from A-3 to A-1 and slightly increases to reach Adult stage, although still being below Brooks' rule. The Upper Permian patterns are unstable, decreasing strongly from A-4 to A-2 for $\mathrm{K}_{\mathrm{L}}$ and from A-4 to A-1 for $\mathrm{K}_{\mathrm{H}}$. The end of the ontogenetic development is characterized by a drastic increase in both $\mathrm{K}_{\mathrm{H}}$ and $\mathrm{K}_{\mathrm{L}}$, indicating that for Paraparchites chenshii, the Adult stage should have been the most resilient. Until now, this pattern has never been observed for other organisms through the Permian. It is discussed further below.

Long-term size changes through the entire Permian are here recorded for the first time for Palaeocopid ostracods. The dimensions of Cyathus caperata document an overall decrease ranging from $17 \%$ to $56 \%$, coordinated with the increase in the growth rates through the Permian. Paraparchites chenshii does not display strong size modifications from the Early to the Middle Permian. However, the Middle-Upper Permian transition corresponds to a decrease in size ranging from $5 \%$ to $27 \%$, accompanied by variable growth rates. 


\section{PRECOCIOUS SEXUAL DIMORPHISM}

Sexual dimorphism is widely known for ostracods throughout their history (Ozawa 2013). This pattern seems to be more pronounced in the adults than in the juveniles (Kamiya 1992). For Podocopida, sexual dimorphism of the carapace (abbreviated here as SDC) is a consequence of sexually dimorphic appendages and appearance/maturation of sexual organs. As an example, possible Anlage (first developmental stage) of the hemipenis is reported in A-2 of the recent Uncinocythere occidentalis, but external dimorphism of the carapace only becomes visible in A-1, females being larger than males (Smith and Kamiya 2005). On average, the adult females are $17 \%$ longer and 22\% higher than the adult males of this species (Smith and Kamiya 2001). Other works also report such precocious SDC for recent Podocopida (e.g. Cyprideis torosa, Cytheromorpha acunpunctata, Heterocythereis albomaculata, Loxoconcha elliptica) in the last one or two juvenile stages before Adult (Rohr 1979; Van Harten 1983; Ikeya and Ueda 1988; Athersuch et al. 1989). Anlagen of reproductive organs being visible and evident in A-1 or A-2 in some recent Podocopida species, it is reasonable that SDC becomes visible at that stage (Ikeya and Ueda 1988). Ikeya and Ueda (1988) considered that precocious sexual dimorphism should be common if Podocopida's sex is genetically determined and that these features are unobserved in young instars because of the small sexual differences between males and females. In the fossil record, six Bathonian Podocopida and one Silurian Myodocopida species document SDC as early as A-5 (Whatley and Stephens 1977; Perrier et al. 2007). Similarly, some Palaeocopida species display sexual dimorphism from A-3 onward (Jaanusson 1956; Martinsson 1956; Guber 1971; Whatley and Stephens 1977). However, life cycles and ontogenetic timings vary among taxa, so the time of appearance of SDC should also vary, as confirmed by the fossil record.

The growth of ostracods by moulting produces punctuated changes in the carapaces during their ontogeny, potentially observable in the fossil record. Fourteen of the 80 species recovered from the Permian-Triassic time interval at the Elikah River section yielded enough specimens to reconstruct the successive ontogenetic stages, down to A-6 for Fabalicypris parva (Fig. 6) and Knightina bullaensis (Fig. 20). Seven of these species clearly display two morphs: Fabalicypris parva, Microcheilinella rectodorsata, M. alborzella, Cyathus elliptica, Paraparchites chenshii, Samarella victori and S. meishanella. For each of these species, the two morphs could represent theoretically intraspecific variations due to ontogenetic or environmental factors, or the occurrence of two separated species. But the latter hypothesis is rejected: contrary to the frequent intraspecific variations observed on PTB ostracods, no continuous variation in characters is observed between the two morphs of each species. Moreover, the two morphs always co-occur and are not isolated morphs. The observed patterns in the Elikah River material are typical of SDC, which is here documented for the first time for those seven species. Based on uniformitarianism, we therefore consider that the larger/longer morphs correspond to females. Sexually dimorphic ornamentation could also potentially be visible for Cyathus elliptica, but the preservation state made it impossible to confidently decide whether the absence of ornamentation is due to initial absence or to degradation. 
TABLE 2. Proportion of change of Lmin, Lmean, $L_{\max }$ and $\mathrm{H}_{\min }, \mathrm{H}_{\text {mean, }} \mathrm{H}_{\max }$ calculated for the successive ontogenetic stages of Cyathus caperata (Guan) and Paraparchites chenshii Crasquin through the Early, Middle (Thailand: Chitnarin et al. 2012) and Late Permian (Cyathus caperata: China, Guizhou: Guan et al. 1978; Meishan GSSP, Zhejiang: Crasquin et al. 2010a; Iran: this work. Paraparchites chenshii: China, Guangxi: Shi and Chen 2002; Meishan GSSP, Zhejiang: Crasquin et al. 2010a, Serbia: Crasquin et al. 2010b, Iran: this work).

\begin{tabular}{|c|c|c|c|c|c|c|}
\hline & $\mathrm{L}_{\min }$ & $\mathrm{L}_{\text {mean }}$ & $\mathrm{L}_{\max }$ & $\mathrm{H}_{\min }$ & $\mathrm{H}_{\text {mean }}$ & $\mathrm{H}_{\max }$ \\
\hline \multicolumn{7}{|c|}{ Cyathus caperata } \\
\hline \multicolumn{7}{|c|}{ Early-Middle Permian (\%) } \\
\hline Adult & -17 & -17 & -17.5 & -22 & -22 & -22.5 \\
\hline A-1 & -27 & -25 & -21.5 & -25 & -23 & -20.5 \\
\hline A-2 & -33 & -30.5 & -29 & -34.5 & -30.5 & -25 \\
\hline \multicolumn{7}{|c|}{ Middle-Late Permian (\%) } \\
\hline Adult & -9 & -0.5 & 5.5 & 2.5 & 20.5 & 44.5 \\
\hline A-1 & -24 & -7.5 & -0.1 & -10 & -1.5 & 4 \\
\hline A-2 & -2 & -5.5 & -7 & 1.5 & -3.5 & -10 \\
\hline \multicolumn{7}{|c|}{ Total Early-Late Permian (\%) } \\
\hline Adult & -24.5 & -17.5 & -18 & -20 & -6.5 & 12 \\
\hline A-1 & -45 & -30.5 & -21.5 & -32.5 & -24 & -17 \\
\hline A-2 & -34.5 & -34.5 & -34 & -33.5 & -32.5 & -32.5 \\
\hline$A-3$ & -36 & -38.5 & -40 & -36 & -37.5 & -39 \\
\hline A-4 & -56 & -48 & -40 & -47 & -42.5 & -40 \\
\hline \multicolumn{7}{|c|}{ Paraparchites chenshii } \\
\hline \multicolumn{7}{|c|}{ Early-Middle Permian (\%) } \\
\hline Adult & 0.8 & 0 & -0.8 & 9 & 9 & 8.5 \\
\hline \multicolumn{7}{|c|}{ Middle-Late Permian (\%) } \\
\hline Adult & -0.5 & 4 & 9 & 9 & 12 & 15.5 \\
\hline A-1 & -13.5 & -11 & -6 & -8 & -10 & -11 \\
\hline A-2 & -21.5 & -20.5 & -20 & -10 & -7.5 & -5.5 \\
\hline$A-3$ & -22 & -16 & -10.5 & -25.5 & -21 & -14.5 \\
\hline A-4 & -27 & -26 & -23.5 & -31 & -24 & -22 \\
\hline
\end{tabular}

\section{HETEROCHRONIES THROUGH THE PERMIAN AND END-PERMIAN EXTINCTION}

Heterochronic changes can modify the rates and/or timing of the ontogenetic formation of the morphological characteristics of an organism. They might affect either the rate of development, or the onset or offset times of characters. Two types of heterochrony are distinguished. Paedomorphosis is the presence of immature structures in an Adult stage and might be the result of deceleration (slower rate), hypomorphosis (earlier offset time) or postdisplacement (later onset time). Peramorphosis corresponds to the occurrence of mature characteristics in immature stages, caused by acceleration (faster rate), hypermorphosis (later offset time) or predisplacement (earlier onset time; Reilly et al. 1997; Haug et al. 2010). Paedomorphosis is regarded as an adaptative mechanism to cope with ecological and environmental perturbations associated with biotic crises (Harries et al. 1996). It has been shown that heterochronies (hypermorphosis and predisplacement) played a crucial role in the early evolution of crustaceans (Haug et al. 2010). They are also implicated in the speciation mechanisms of the ostracod Loxoconcha species during the Pliocene-Pleistocene in the Western Pacific (Tanaka and Ikeya 2002). Postdisplacement is known for recent ostracods (Chrysocythere ornata) of the Congo platform as a colonization mechanism under strong seasonal upwelling and/or active sedimentation (Bertholon 1997). As far as we know, the same work documents the only predisplacement mechanisms known for ostracods as an answer to upwelling establishment in the Miocene-Pliocene of Morocco. They consider that the environmental conditions induced by the upwelling of deep waters are causes for postdisplaced or predisplaced developments and that continental influx favours hypomorphosis. Recently, we documented seven ostracod species with heterochronic development in the lowermost Triassic microbialites of Turkey: six of them display slow growth rates (four Podocopida and 
two Palaeocopida), while one had fast growth (Palaeocopida). They are interpreted as the secondary adaptative mechanisms to deleterious environment in the aftermath of the extinction, resulting in fecundity and voltinism modifications to maintain viable populations (Forel 2014).

In the present study, the appearance time of SDC during the ontogeny of the recovered ostracods is of utmost importance in detecting the possible heterochronies and modification of the fecundity/voltinism. They are privileged insights into the palaeobiology of those organisms, some of which went extinct (Palaeocopida), while others succeeded in reconquering environments where they occur to the present day (e.g. Podocopida, Bairdioidea). The material presented here allows not only short-term analysis through the PTB but also long-term view through the overall Permian thanks to long-time-span Palaeocopida species present during the Early-Middle Permian of Thailand (Chitnarin et al. 2012).

The SDC onset time for the six species under scrutiny is variable among the different taxa and in time, as summarized in Table 3. Considering Palaeocopida, our record of dimorphism in A-3 of Cyathus elliptica and Samarella victori in the Late Permian of Iran confirms the previous mentions of precocious SDC for this order. It seems that such precocity was relatively common for Palaeocopida through their evolution. However, the occurrence of SDC in A-5 of Samarella meishanella is the first known record of strong precocity for this order. Considering the abovementioned existence of such precocity in Podocopida and Myodocopida, it seems reasonable that some Palaeocopida might display similar patterns, keeping in mind that SDC does not imply simultaneous sexual maturity.

Paraparchites chenshii is the only species for which the time of appearance of SDC can be investigated from the Middle to Late Permian. This onset time differs between the Middle and Late Permian, from A-2 to A-4, respectively. The present data therefore document a shift of the

TABLE 3. Summary of ontogenetic time of appearance of carapace sexual dimorphism in Fabalicypris parva, Microcheilinella rectodorsata (Podocopida), Cyathus elliptica, Paraparchites chenshii, Samarella victori and S. meishanella (Palaeocopida) from the present work.

\begin{tabular}{lll}
\hline Species & Age & $\begin{array}{l}\text { Onset time } \\
\text { of SDC }\end{array}$ \\
\hline Fabalicypris parva & Late Permian & A-3 \\
Microcheilinella rectodorsata & Late Permian & A-5 \\
Cyathus elliptica & Late Permian & A-3 \\
Paraparchites chenshii & Late Permian & A-4 \\
Samardla victori & Early Permian & A-2 \\
Samardla meishanella & Late Permian & A-3 \\
\hline
\end{tabular}

SDC onset time in Paraparchites chenshii towards an appearance of dimorphic patterns in younger instars in the Late Permian (Table 3). This precocious appearance of morphological characters reflects a faster ontogeny of the species in the Late Permian compared to the Middle Permian corresponding to a peramorphosis by predisplacement. As stated above, this shift of SDC onset time is coupled with a reduction in the size of all ontogenetic stages, except the Adult, from the Middle to Late Permian, and faster growth for the Middle Permian specimens, except for the transition to Adult stage.

Two hypotheses can account for this unprecedented pattern:

1. Paraparchites chenshii occurs rarely in the Early Permian of Thailand (Chitnarin et al. 2012), and the only two specimens found did not allow any conclusion to be drawn regarding the ontogeny of the species during this interval. This newly recorded heterochrony might be linked to the Guadalupian- Lopingian transition, corresponding to a primary short-term response to extinction-linked events (Isozaki 2003; Shen and Shi 2009). However, little is known about the extinction patterns of ostracods through the Guadapupian-Lopingian boundary (Crasquin and Forel 2014), and it is for the moment not possible to deepen this hypothesis. 
2. While we previously recognized short-term heterochronies following the end-Permian events (Forel 2014), Paraparchites chenshii could record a longer trend spanning the Middle and Late Permian, implying forcing parameters of different scale. Short-term patterns through the PTB (the heterochronies and Lilliput effect) might be related to short-term and relatively rapid environmental/ecological events related to the end-Permian extinction (Forel 2014). Long-term adaptations highlighted by the present work might rather reflect climatic forcing.

The Middle Permian Paraparchites chenshii were discovered in the Sawan and Phetchabun provinces in central Thailand (Chitnarin et al. 2012), part of the Indochina block during the Permian (Metcalfe 2011). Throughout the Permian, the Indochina block was located in the subtropical belt, on the eastern edge of Palaeo-Tethys at the transition with Panthalassa (e.g. Metcalfe 2002; Angiolini et al. 2013 and references therein). The Iran microplate might have occupied slightly similar latitude during the Late Permian (Gaetani et al. 2009). However, global climatic conditions varied drastically during the Permian: the earliest Permian ice maximum was followed by a complete shift to greenhouse, followed by three more localized glacial episodes centred in eastern Australia (Isbell et al. 2003; Fielding et al. 2008a, b). The recent reconstructions of the mean temperatures in tropical areas and of the highlatitude $\mathrm{d}^{18} \mathrm{O}$ document large climatic changes through the Permian, the largest during the Sakmarian-Artinskian (Early Permian; cool to warm shift) and during the Kungurian- Roadian (Early-Middle Permian; warm to cool shift). However, the global trend is of an increase in temperatures during the overall Permian (Montanez et al. 2007; Korte et al. 2008).

Temperature plays a primordial role in shaping the distribution of marine organisms. Their occurrence and survival are closely related to maximum and minimum temperatures, and their thermal tolerance is correlated with respiratory deterioration and the onset of anaerobic metabolism (Portner et al. 1999; Frederich and Portner 2000; Wabete et al. 2008). A strong correlation has been documented between growth rate and rising sea temperature for Recent giant clams, with erratic growth above $27^{\circ} \mathrm{C}$ (Schwartzmann et al. 2011). Many crustaceans show the strong negative effects of temperature on their energy metabolism (Verslycke and Janssen 2002; Wabete et al. 2008). Among them, copepods are able to alternate between univoltine and multivoltine reproduction following temperature conditions (Gerten and Adrian 2002; Winder and Schindler 2004; Adrian et al. 2009). Ostracods are highly sensitive to temperature, affecting both their growth and reproductive patterns. In the fossil record, the body size of deep-sea ostracods has been linked to climate change, ostracods getting larger as climate got colder (Hunt et al. 2010). Similarly, dwarfing has been documented during the Paleocene- Eocene Thermal Maximum (PETM) in response to high temperatures: ostracod food consumption rates and lifetime might have been reduced compared to their prePETM counterparts, increasing their growth rates (Yamaguchi et al. 2012). In modern ecosystems, low temperatures cause deceleration of growth for several Cypridoidea (Podocopida; Ganning 1971), while many species develop faster at higher temperatures (Cohen and Morin 1990). The reproduction rate of the recent freshwater Heterocypris barbara (Gauthier and Brem 1928) is doubled under fluctuating temperatures, leading to the idea that more generations in a given period allow faster adaptations for freshwater ostracods (Rossi et al. 2003, 2013; Forrest and Miller-Rusching 2010).

The present observation of shift in the SDC precocity of Paraparchites chenshii co-occurs with a decrease in the overall body size and growth rates of at least two Palaeocopida species from the Middle to Late Permian. Although specimens of Paraparchites chenshii are not abundant enough in the Early Permian, the size/growth pattern of Cyathus caperata seems to indicate that the physiological modifications at the origin of these changes began in the Early Triassic. As stated above, the observed size, growth and reproduction changes through time might reflect temperature modifications. Referring to the observation of ostracods getting larger in colder climate (Hunt et al. 2010), we interpret the trends of Palaeocopida (Paraparchites chenshii and Cyathus caperata) as temperature dependent, reflecting the global warming during the overall Permian. It is also interesting to note that the size change of Cyathus caperata is much stronger from the Middle to Late Permian than from the Early to Middle Permian. It might imply that this species was more deeply affected by the GuadalupianLopingian events than by the temperature increase. A statistical analysis in progress will allow clarify these conclusions.

Until recent works investigating temperature changes through the PTB and Early Triassic (e.g. Sun et al. 2011; Schobben et al. 2014), most attention was given to oxygenation state as one of the triggers of extinction/slow recovery. Our knowledge of the Recent and fossil ostracod record during this interval is one of the arguments to rule out such a one-parameter system. All the ostracod patterns documented during the Permian (this work) and through the PTB and subsequent recovery (Forel et al. 2013a; see Crasquin and Forel 2014 for synthesis) have been studied under the aspect of oxygenation issues. As stated above, temperature is a fundamental parameter for all marine organisms and its effects on both community structure and individual characteristics are often neglected. However, the observed impacts of temperature state on modern ostracods are very similar to the features observed in Permian and PTB assemblages. Short-term changes in ostracod assemblages and physiology might also be related to the temperature rise recorded through the PTB in the Palaeo-Tethys (Schobben et al. 2014). Similarly, the acidification of waters has huge impacts on the physiology and ecology of modern organisms (e.g. Whiteley 2011 for crustaceans), with patterns similar to those observed 
for issues concerning oxygenation and temperature. Our recent works on the ostracods of the Permian-Triassic interval document their strong ability to modulate their physiology and life rhythms to adapt to long-term climatic changes and to temporarily successfully colonize microbial refuge in the aftermath of the end-Permian extinction. This strong plasticity is observed at the community level with change in their composition and at the individual level with heterochronies and intraspecific variations. The present data illustrate the wide variety of ostracods' physiological responses to climatic and environmental changes through the Permian and PTB. Future works have to be aimed at drawing a synthetical view of ecosystems by integrating crucial parameters such as the oxygen levels, the temperature and the acidification of the waters.

Acknowledgements. This work is part of IGCP 572 'Restoration of marine ecosystems following the Permian-Triassic mass extinction: lessons for the present' and was funded by Actions Transversales du Museum (ATM) Biodiversites actuelles et fossiles. It was undertaken at the UMR 7207 Centre de recherche sur la paleobiodiversite et les paleoenvironnements (CR2P), Paris. We thank Dr Avraham Honigstein (Israel Geological Survey) and Dr Robin Whatley (University of Wales, United Kingdom) for their careful corrections and comments that greatly improved an earlier version of the present manuscript. We are grateful to the Editorial team of the journal Palaeontology for their help in the formatting of the present article. We thank Martine Fordant and Alexandre Lethiers (Pierre et Marie Curie Universite, Paris 6), for their help with the processing of the samples and the drawings, respectively. We are very thankful to Brigitte Letang for patiently revising the English of the present work.

\section{REFERENCES}

ABE, K. and VANNIER, J. 1991. Mating behavior in the podocopid ostracode Bicornucythere bisanensis (Okubo, 1975): rotation of a female by a male with asymmetric fifth limbs. Journal of Crustacean Biology, 11, 250-260.

--1993. Significance of a heart in the Myodocopa (Ostracoda): exemplified by the peculiar morphology and ecology of a luminescent species. American Zoologist, 33, 81A.

ADRIAN, R., O’ REILlY, C. M., ZAGARESE, H., BAINES, S. B., HESSEN, D. O., KELLER, W., LIVINGSTONE, D. M., SOMMARUGA, R., STRAILE, D., VAN DONK, E., WEYHENMEYER, G. A. and WINDERL, M.

2009. Lakes as sentinels of climate change. Limnology and Oceanography, 54, 2283-2297.

AL-BELUSHI, J., GLENNIE, K. W. and WILLIAMS, B.

P. J. 1996. Permo-Carboniferous Glaciogenic Al Khlata Formation, Oman: a new hypothesis for origin of its glaciation. GeoArabia, 1, $389-403$.

ALAVI, M. 1991. Sedimentary and structural characteristics of the Paleo-Tethys remnants in northeastern Iran. Geological Society of America Bulletin, 103, 983-992.

ANGIOLINI, L. and CARABELLI, L. 2010. Upper Permian brachiopods from the Nesen Formation, North Iran. Special Papers in Palaeontology, 84, 41-90.
BALINI, M., GARZANTI,
E., NICORA,
A. and

TINTORI, A. 2003. Gondwanan deglaciation and opening of Neo-Tethys: palaeontological and sedimentological evidence from interior Oman. Palaeogeography, Palaeoclimatology, Palaeoecology, 196, 99-124.

-CHECCONI, A., GAETANI, M. and RETTORI, R.

2010. The latest Permian mass extinction in the Alborz Mountains (North Iran). Geological Journal, 45, 216-229.

CRIPPA, G., MUTTONI, G. and PIGNATTI, J.

2013. Guadalupian (Middle Permian) paleobiogeography of the Neotethys Ocean. Gondwana Research, 24, 173-184.

ATHERSUCH, J., HORNE, D. J. and WHITTAKER,

J. E. 1989. Marine and brackish water ostracods (superfamilies Cypridacea and Cytheracea). Synopses of the British Fauna (New Series), Vol. 43. Linnean Society of London and Estuarine and Coastal Sciences Association, E. J. Brill, Leiden, 343 pp.

BAIRD, W. 1845. Arrangement of the British Entomostraca, with a list of species, particularly noticing those which have as yet been discovered within the bounds of the club. Transactions of the Berwickshire Naturalists' Club, Edinburgh, 2, 145-158. -1850. The natural history of the British Entomostraca. Ray Society, London, 364 pp.

BERBERIAN, M. and KING, G. C. P. 1981. Toward a paleogeography and tectonic evolution of Iran. Canadian Journal of Earth Sciences, 18, 210-265.

BERDAN, J. and SOHN, I. G. 1961. Family Pachydomellidae Berdan \& Sohn, n. fam. Q373-Q374. In MOORE, R. C. and PITRAT, C. W. (eds). Treatise on invertebrate paleontology, Part Q, Arthropoda 3. Geological Society of America, Boulder, CO \& University of Kansas Press, Lawrence, KS, 442 pp.

BERTHOLON, L. 1997. Les heterochronies du developpement chez les ostracodes, indicateurs de strategies adaptatives. Geobios, $21,277-285$. BESSE, J., TORCQ, F., GALLET, Y., RICOU, L. E., KRYSTYN, L. and SAIDI, A. 1998. Late Permian to Late Triassic palaeomagnetic data from Iran: constraints on the migration of the Iranian block through the Tethyan Ocean and initial destruction of Pangaea. Geophysical Journal International, 135, 72-92. 
BOND, D. P. G., WIGNALL, P. B., WANG, W., IZON, G., JIANG, H. S., LAI, X. L., SUN, Y. D., NEWTON, R. J., SHAO, L. Y., VEDRINE, S. and COPE, H. 2010. The mid-Capitanian (Middle Permian) mass extinction and carbon isotope record of South China. Palaeogeography, Palaeoclimatology, Palaeoecology, 292, 282-294.

BROOKS, W. K. 1886. Report on the Stomatopoda dredged by H. M.S. "Challenger" during the years 1873-1876. Report on the scientific results of the voyage of H.M.S. Challenger Zoology, 16, 1-116.

BURRETT, B., UDCHACHON, M., THASSANAPAK,

H. and CHITNARIN, A. 2014. Conodonts, radiolarians and ostracodes in the Permian E-Lert Formation, Loei Fold Belt, Indochina Terrane, Thailand. Geological Magazine, 152 (1), 106-142.

CHEN, T. C. 1958. Permian ostracods from the Chihsia Limestone of Lungtan, Nanking. Acta Palaeontologica Sinica, 6, $235-257$.

CHEN, D. Q. and BAO, H. 1986. Lower Permian Ostracodes from the Chihsia Formation of Jurongand Longtar, Jiangsu Province. Acta Micropalaeontologica Sinica, 3, 107-132. -and SHI, C. G. 1982. Latest Permian Ostracoda from Nantong, Jiangsu and from Miannyang, Hubei. Bulletin of Nanjing Institute of Geology and Palaeontology, Academia Sinica, 4, 105-152. [in Chinese with English abstract]

CHEN, Z. Q., KAIHO, K. and GEORGE, A. D. 2005a. Survival strategy of brachiopod from the end-Permian mass extinction. Palaeogeography, Palaeoclimatology, Palaeoecology, 224, 232-269.

---2005b. Early Triassic recovery of brachiopod faunas from the end-Permian mass extinction: a global review. Palaeogeography Palaeoclimatology, Palaeoecology, 224, 270-290.

CHITNARIN, A., CRASQUIN, S., CHAROENTITIRAT, T., TEPNARONG, P. and THANEE, N. 2012. Ostracods

(Crustacea) of the Early-Middle Permian from Central Thailand (Indochina block). Part I. Order Palaeocopida. Geodiversitas, 34, 801-835.

COHEN, A. C. and MORIN, J. G. 1990. Patterns of reproduction in ostracodes; a review. Journal of Crustacean Biology, 10, $184-211$.

COOPER, C. L. 1946. Pennsylvanian Ostracodes of Illinois. Bulletin State Geological Survey of Illinois, 70, 1-177.

CORYELL, H. N. 1928. Some new Pennsylvanian Ostracoda.

Journal of Paleontology, 2, 377-381.

-and BOOTH, R. T. 1933. Pennsylvanian Ostracoda; a continuation of study of Ostracoda fauna from the Wayland Shale, Graham, Texas. American Midland Naturalist, 14, 258-278.

CRASQUIN, S. and FOREL, M. B. 2014. Ostracods (Crustacea) through Permian-Triassic events. Earth-Science Reviews, $137,52-64$. doi:10.1016/j.earscirev.2013.01.006

-PERRI, M. C., NICORA, A. and DE WEVER, P.

2008. Ostracods across the Permian-Triassic boundary in Western Tethys: the Bulla parastratotype (Southern Alps, Italy). Rivista Italiana di Paleontologia e Stratigrafia, 114, 233-262.

-FOREL, M. B., FENG, Q., YUAN, A., BAUDIN, F. and COLLIN, P. Y. 2010a. Ostracods (Crustacea) through Permian-Triassic boundary in South China: the Meishan stratotype (Zhejiang Province). Journal of Systematic Palaeontology, 8, 331-370.

-SUDAR, M., JOVANOVIC, D. and KOLAR-JUR-

KOVSEK, T. 2010b. Ostracod fauna from Late Permian of Jadar Block (Vardar Zone, NW Serbia). Geoloski Anali Balkanskoga Poluostrva, $71,23-35$.

CRASQUIN-SOLEAU, S. and KERSHAW, S. 2005. Ostracod fauna from the Permian-Triassic boundary interval of South China (Huaying Mountains, eastern Sichuan Province): palaeoenvironmental significance. Palaeogeography, Palaeoclimatology, Palaeoecology, 217, 131141.

-BROUTIN, J., BESSE, J. and BERTHELIN, M. 2001. Ostracodes and paleobotany from the Middle Permian of Oman: implications on Pangea reconstruction. Terra Nova, 13, 38-43.

- RICHOZ, S., MARCOUX, J., ANGIOLINI, L., NICORA, A. and BAUD, A. 2002. The events of the

Permian-Triassic boundary: last survivors and/or first colonizers among the ostracods of the Taurides (southwestern Turkey). Comptes Rendus Geoscience, 334, 489-495. -MARCOUX, J., ANGIOLINI, L. and NICORA, A.

2004a. Palaeocopida (Ostracoda) across the Permian-Triassic events: new data from the South-Western Taurus (Turkey). Journal of Micropalaeontology, 23, 67-76.

----and BERTHO Y. 2004b. New ostracode fauna from Permian-Triassic boundary in Turkey (Taurus, Antalya Nappes). Micropalaeontology, 50, 281-296.

-VASLET, D. and LE NINDRE, Y. M. 2005. Ostracods from Permian-Triassic boundary in Saudi Arabia (Khuff Formation). Palaeontology, 48, 853-868.

- GALFETTI, T., BUCHER, H. and BRAYARD, A.

2006a. Early Triassic ostracods from Guangxi Province, South China. Rivista Italiana di Paleontologia e Stratigrafia, 112, 55-75.

-VASLET, D. and LE NINDRE, Y. M. 2006b. Ostracods of Permian-Triassic Khuff Formation, Saudi Arabia: paleoecology and paleobiogeography. GeoArabia, 11, 55-76.

-SHEN, S. Z., LI, W. Z. and CAO, C. Q. 2007. Ostracods from the Lopingian and the Permian-Triassic boundary beds at the Gyanyima section in southwestern Tibet, China. Palaeoworld, 16, 222-232. 
DELO, D. M. 1930. Some Upper Carboniferous Ostracoda from the shale basin of Western Texas. Journal of Paleontology, 4, 152-178.

DERCOURT, J., RICOU, L. E. and VRIELYNCK, B.

1993. Atlas Tethys Palaeonvironmental Maps. Gauthiers Villars, Paris, 14 maps.

- GAETANI, M., VRIELYNCK, B., BARRIER, E., BIJU-DUVAL, B., BRUNET, M. F., CADET, J. P., CRASQUIN, S. and SANDULESCU, M. (ed.). 2000.

Atlas Peri-Tethys, Palaeogeographical Maps. CCGM/CGMW, Paris. Explanatory notes, I-XX + 269 pp., and 24 maps.

EGOROV, V. G. 1950. Frasnian ostracods from Russian platform. I. Kloedenellitidae. VNIGRI (All Russia Petroleum Research Exploration Institut), Moscow, 175 pp. [in Russian]

-1953. Ostracodes from the Frasnian of the Russian Platform; II-Bairdiidae, Hollinidae, Kirkbyidae. VNIGRI (All Russia Petroleum Research Exploration Institut), Moscow, 133 pp. [in Russian]

ERWIN, D. H. 1993. The Great Paleozoic Crisis: life and death in the Permian. Columbia University Press, New York, 327 pp.

FIELDING, C., FRANK, T., BIRGENHEIER, L., RYGEL, M., JONES, A. and ROBERTS, J. 2008a. Stratigraphic imprint of the late Palaeozoic Ice Age in eastern Australia: a record of alternating glacial and nonglacial climate regime. Journal of the Geological Society, 165, 129-140.

--and ISBELL J. 2008b. The late Paleozoic ice age: a review of current understanding and synthesis of global climate patterns. 343-354. In FIELDING, C., FRANK, T. and ISBELL, J. (eds). Resolving the Late Paleozoic ice age in time and space. Geological Society of America Special Paper, 441, Boulder, CO, 356 pp.

FOREL, M. B. 2012. Ostracods (Crustacea) associated with microbialites across the Permian-Triassic boundary in Dajiang (Guizhou Province, South China). European Journal of Taxonomy, 19, 1-34.

- 2013. The Permian-Triassic mass extinction: Ostracods (Crustacea) and microbialites. Comptes Rendus Geoscience, 345, $203-2011$.

-2014. Heterochronic growth of ostracods (Crustacea) from microbial deposits in the aftermath of the end-Permian extinction. Journal of Systematic Palaeontology, published online 14 May 2014. doi:10.1080/14772019.2014.902400

- and CRASQUIN, S. 2011a. Lower Triassic ostracods (Crustacea) from Meishan section, Permian-Triassic GSSP (Zhejiang Province, South China). Journal of Systematic Palaeontology, 9, 455-466.

-- 2011b. In the aftermath of the Permian-Triassic boundary mass extinction: ostracod new species and genus from South Tibet. Geodiversitas, 33 , 247-263.

--KERSHAW, S., FENG, Q. and COLLIN, P. Y.

2009. Ostracods (Crustacea) and water oxygenation in earliest Triassic of South China: implications for oceanic events of the end-Permian mass extinction. Australian Journal of Earth Sciences, 56, 815-823.

-- BRUHWILER,€ T., GOUDEMAND, N., BU-

CHER, H. and BAUD, A. 2011. Ostracod recovery after Permian-Triassic boundary mass-extinction in South Tibet. Palaeogeography, Palaeoclimatology, Palaeoecology, 308, 160- 170.

--KERSHAW, S. and COLLIN, P. Y. 2013a. In the aftermath of the end-Permian extinction: the microbialite refuge? Terra Nova, 25, 137-143.

--HIPS, K., KERSHAW, S., COLLIN, P. Y. and

HAAS, J. 2013b. Ostracods (Crustacea) from Permian-Triassic Boundary of Balvany North section (Bukk Mountains, € Hungary). Acta Palaeontologica Polonica, 58, 195-219.

--CHITNARIM, A., ANGIOLINI, L. and GAE-

TANI, M. 2015. Data from: precocious sexual dimorphism and the Lilliput effect in Neo-Tethyan Ostracoda (Crustacea) through the PermianTriassic boundary. Dryad Digital Repository, doi:10.5061/dryad.cd0cq

FORREST, J. and MILLER-RUSCHING, A. J. 2010.

Toward a synthetic understanding of the role of phenology in ecology and evolution. Philosophical Transactions of the Royal Society of London, Series B: Biological Sciences, 365, 3101-3112.

FRAISER, M. L. and BOTTJER, D. J. 2004. The non-actualistic Early Triassic gastropod fauna: a case study in the Lower Triassic Sinbad Limestone member. Palaios, 19, 259-275.

--2007. Elevated atmospheric $\mathrm{CO}_{2}$ and the delayed biotic recovery from the End-Permian extinction. Palaeogeography, Palaeoclimatology, Palaeoecology, 252, 164-175.

FREDERICH, M. and PORTNER, H. O. 2000. Oxygen limi-€ tation of thermal tolerance defined by cardiac and ventilatory performance in spider crab, Maja squinado. American Journal of Physiology, 279, R1531-R1538.

GAETANI, M., ANGIOLINI, L., KATSUMI, U., NICORA, A., STEPHENSON, M. H., SCIUNNACH, D., RETTORI, R., PRICE, G. D. and SABOURI, J. 2009.

Pennsylvanian - Early Triassic stratigraphy in Alborz Mountains

(Iran). 79-128. In BRUNET, M. F., WILMSEN, M. and GRANATH, J. W. (eds). South Caspian to Central Iran Basins. Geological Society, London, Special Publication, 312, 367 pp.

GANNING, B. 1971. On the ecology of Heterocypris salinus, H. incongruens and Cypridopsis aculeata (Crustacea, Ostracoda) from Baltic brackish-water rockpools. Marine Biology, 8, 271-279.

\section{[Digitare qui]}


GARZANTI, E. 1999. Stratigraphy and sedimentary evolution of the Nepal Tethys Himalaya passive margin. 805-827. In LEFORT, P. and UPRETI, B. N. (eds). Geology of

Nepal, Recent Advances. Journal of Asian Earth Sciences, 17, 887 pp.

GAUTHIER, H. and BREM, V. 1928. Ostracodes et cladoceres de l'Algerie et de la Tunisie. 3. note. Bulletin de la Societe d'Histoire Naturelle d'Afrique du Nord, 19, 114-121. GEIS, H. L. 1932. Some ostracodes from the Salem Limestone, Mississippian of Indiana. Journal of Paleontology, 6, 149-188. -1933. Microcheilinella, a new name for the ostracode genus Microcheilus. Journal of Paleontology, 7, 112.

GERTEN, D. and ADRIAN, R. 2002. Species specific response of freshwater copepods to recent summer warming. Freshwater Biology, 47, 21632173.

GRUNDEL, J. 1962. Zur Taxonomie der Ostracoden der Gat-€ tendorfia - Stufe Thuringens.€ Freiberger Forschungshefte, 151, 51-105.

-1969. Ostracoden aus der plenus-Zone (Oberkreide) Sachsens. Freiberger Forschungshefte, C245, 83-89.

GUAN, S., SUN, Q., JIANG, Y., LI, L., ZHAO, B., ZHANG, X., YANG, R. and FENG, B. 1978. Subclass Ostracoda. 115-325. In Paleontological Atlas of Central and South China. Geological Publishing House, Beijing, 765 pp. [in Chinese]

GUBER, A. L. 1971. Problems of sexual dimorphism, population structure and taxonomy of the Ordovician genus Tetradella (Ostracoda). Journal of Paleontology, 45, 6-22.

HAMMER, Ø. and HARPER, D. A. T. 2005. Paleontological

Data Analysis. Blackwell, Oxford, $351 \mathrm{pp}$.

-- and RYAN P. D. 2001. PAST: Palaeontological

Statistics software package for education and data analysis. Palaeontologia Electronica, 4, 9.

HAO, W. C. 1992. Lower Triassic marine ostracods from Guizhou. Acta Micropalaeontologica Sinica, 9, 37-44. [in Chinese]

HARLTON, B. H. 1933. Micropaleontology of the Pennsylvanian Johns Valley Shale of Ouachita Mountains, Oklahoma and its relationships to the Mississippian Caney Shale. Journal of Paleontology, 7, 3-29.

HARRIES, P. J., KAUFFMAN, E. G. and HANSEN, T. A.

1996. Models for biotic survival following mass extinction. Geological Society of London, Special Publication, 102, 41-60.

HAUG, J. T., MAAS, A. and WALOSZEK, D. 2010. †Henningsmoenicaris scutula, †Sandtorpia vestrogothiensis gen. et sp. nov. and heterochronic events in early crustacean evolution. Earth and Environmental Science Transactions of the Royal Society of Edinburgh, 101, 1-39.

HAYAMI, I. 1998. Ecology of mass extinctions: the diversity and shell size of bivalves through time. Fossils, 52, 38-44. [in Japanese]

HE, W., SHI, G. R., FENG, Q., CAMPI, M. J., GU, S., BU, J., PENG, Y. and MENG, Y. 2007. Brachiopod miniaturization and its possible causes during the Permian-Triassic crisis in deep-water environments, South China. Palaeogeography, Palaeoclimatology, Palaeoecology, 252, $145-163$. HENNIG, W. 1965. Phylogenetic systematics. Annual Review of Entomology, 10, 97-116.

HENNINGSMOEN,€ G. 1953. Classification of Paleozoic straight hinged Ostracoda. Norsk Geologisk Tidsskrift, 31, $185-288$.

HØ EG, J. T. 1992. The phylogenetic position of the Rhizocephala: are they truly barnacles? Acta Zoologica, 73, 323-326.

HORNE, D. J., BALTANAS, A. and PARIS, G. 1998. Geographical distribution of reproductive modes in living nonmarine ostracods. 7799. In MARTENS, K. (eds). Sex and parthenogenesis: evolutionary ecology of reproductive modes in non-marine ostracods. Backhuys, Leiden, the Netherlands, $336 \mathrm{pp}$.

- COHEN, A. and MARTENS, K. 2002. Taxonomy, morphology and biology of Quaternary and living Ostracoda. 5-36. In HOLMES, J. A. and CHIVAS, A. (eds). The

Ostracoda: applications in Quaternary Research. Geophysical Monograph, American Geophysical Union, Washington, DC, 184 pp.

HUNT, G., WICAKSONO, S. A., BROWN, J. E. and MA-

CLEOD, K. G. 2010. Climate-driven body-size trends in the ostracod fauna of the deep Indian Ocean. Palaeontology, 53, 1255-1268.

IKEYA, N. and ABE, K. 1996. Natural history of the Ostracoda. University of Tokyo Press, 237 pp. [in Japanese]

-and UEDA, H. 1988. Morphological variations of Cytheromorpha acupunctata (Brady) in continuous populations at Hamana-ko Bay, Japan. 319-340. In HANAI, T., IKEYA, N. and ISHIZAKI, K. (eds). Evolutionary biology of Ostracoda. Kodansha, Tokyo, 1356 pp.

INSALACO, E., VIRGONE, A., COURME, B., GAILlOT, J., KAMALI, M., MOALLEMI, A., LOTFPOUR, M. and MONIBI, S. 2006. Upper Dalan Member and Kangan Formation between the Zagros Mountains and offshore Fars, Iran: depositional system, biostratigraphy and stratigraphic architecture. GeoArabia, 11, 75-176.

IRANIAN-CHINESE RESEARCH GROUP. 1995. Field work on the Lopingian stratigraphy in Iran. Permophiles, $27,5-6$.

IRANIAN-JAPANESE RESEARCH GROUP. 1981. The

Permian and the Lower Triassic Systems in Abadeh region, Central Iran. Memoirs Faculty Sciences, Kyoto University, Series Geology and Mineralogy, 47, 61-133.

ISBELL, J., MILLER, M., WOLFE, K. and LENAKER, P.

2003. Timing of late Paleozoic glaciation in Gondwana: was glaciation responsible for the development of northern hemisphere cyclothems?

5-24. In CHAN, M. and ARCHER, A.

(eds). Extreme depositional environments: mega end members in geological time. Geological Society of America Special Paper, 370,281 pp. 
ISOZAKI, Y. 2003. Guadalupian-Lopingian boundary event in mid-Panthalassa: correlation of accreted deep-sea chert and mid-oceanic atoll carbonate. 111-124. In WONG, T. E. (eds). Proceedings of the XVth International Congress on Carboniferous and Permian Stratigraphy. Royal Netherlands Academy of Arts and Sciences, Utrecht, the Netherlands, 584 pp.

JAANUSSON, V. 1956. Untersuchungen uber den oberordovi-€ zischen Lyckholm- Stufenkomplex in Estland. Bulletin of the Geological Institute of Uppsala, 36, 369-400.

-1957. Middle Ordovician ostracodes of Central and Southern Sweden. Geological Institute University Uppsala Bulletin, 37, 176-442.

JASSIM, S. Z. and GOFF, J. C. (eds). 2006. Geology of Iraq. Dolin, Praha, 352 pp.

JENNY-DESHUSSES, C. 1991. The Permian-Triassic in the Gartnerkofel-1 core (Carnic Alps, Austria): foraminifera and algae of the core and outcrop section. 99-108. In HOLSER, W. T. and SCHONLAUB, H. P. (eds).€ The Permian-Triassic boundary in the Carnic Alps of Austria (Gartnerkofel region). Abhandlungen der geologischen Bundesanstalt, 45, 232 pp.

JONES, T. R. 1901. On some Carboniferous shale from Siberia. Geological Magazine, 8, 433-436.

KAMIYA, T. 1992. Different sex-ratio in two Recent species of Loxoconcha (Ostracoda). Senckenbergiana Lethaia, 68, $337-345$.

-OZAWA, H. and OBATA, M. 2001. Quaternary and

Recent marine Ostracoda in Hokuriku district, the Japan Sea coast. 73-106. In IKEYA, N. (eds). Field excursion guidebook of the 14th International Symposium of Ostracoda, Shizuoka. Organising Committee of 14th ISO, Shizuoka.

KELLETT, B. 1933. Ostracodes of the Upper Pennsylvanian and the Lower Permian Strata of Kansas: I. The Aparchitidae, Beyrichiidae, Glyptopleuridae, Kloedenellidae, Kirkbyidae, and Youngiellidae. Journal of Paleontology, 7, 59-108.

- 1935. Ostracodes of the Upper Pennsylvanian and the Lower Permian strata of Kansas: III. Bairdiidae (concluded), Cytherellidae, Cypridinidae, Entomoconchidae, Cytheridae and Cypridae. Journal of Paleontology, 9, 132-166.

KNIGHT, J. B. 1928. Some Pennsylvanian Ostracodes from the Henrietta Formation of Eastern Missouri (part 1). Journal of Paleontology, 3, 229267.

KORTE, C., JONES, P., BRAND, U., MERTMANN, D. and VEIZER, J. 2008. Oxygen isotope values from high-latitudes: clues for Permian seasurface temperature gradients and late Palaeozoic deglaciation. Palaeogeography, Palaeoclimatology, Palaeoecology, $269,1-16$.

KOTCHETKOVA, H. M. and GUSEVA, E. A. 1972. Rannepermskije ostrakody juznogo i srednego Priurala. Doklady Akademii Nauk SSSR, Baszkirskij Fil. Inst. Geol., 1-180.

KOZUR, H. 1985. Neue Ostracoden-Arten aus dem Oberen Mittelkarbon (hoheres Moskovian), Mittel- und Oberperm des€ Bukk-Gebirges (NUngarn).€ Geologische Pal€aontologische Mitteilungen, Special Issue 2, 1-145.

-1996. The conodonts Hindeodus isarcicella and Sweetohindeodus in the Uppermost Permian and Lowermost Triassic. Geologia Croatica, 49, 81115.

-and METTE, W. 2006. Iranokirkbya brandneri n. gen. n. sp., a new kirkbyid ostracod from the Late Permian (Dorashamian) of Zal, NW Iran. Geo.Alp, 3, 85-91.

LATREILLE, P. A. 1806. Genera crustaceorum et insectorum: secundum ordinem naturalem in familias disposita, iconibus exemplisque plurimis explicata. Tomus 1. Koenig, Paris, 303 pp.

LEDA, L., KORN, D., GHADERI, A., HAIRAPETIAN, V., STRUCK, U. and REIMOLD, W. U. 2014. Lithostratigraphy and carbonate microfacies across the Permian-Triassic boundary near Julfa (NW Iran) and in the Baghuk Mountains (Central Iran). Facies, 60 (1), $295-325$.

doi:10.1007/s10347-013-0366-0

LEIGHTON, L. R. and SCHNEIDER, C. L. 2008. Taxon characteristics that promote survivorship through the Permian-Triassic interval: transition from the Paleozoic to the Mesozoic brachiopod fauna. Paleobiology, 34, 65-79.

LETHIERS, F. 1981. Ostracodes du Devonien terminal de l'Ouest du Canada: systematique, biostratigraphie et paleoecologie. Geobios, 5, 234 pp. -and CRASQUIN-SOLEAU, S. 1988. Comment extraire des microfossiles a tests calcitiques de roches calcaires dures. Revue de Micropaleontologie, 31, 56-61.

MAAS, A., WALOSZEK, D. and MULLER, K. J. 2003.€

Morphology, ontogeny and phylogeny of the Phosphatocopina (Crustacea) from the Upper Cambrian 'Orsten' of Sweden. Fossils \& Strata, 49, 1238.

MADDOCKS, R. F. 1991. New Bairdiidae (Ostracoda) from

Tulear, Madagascar. Journal of Micropalaeontology, 9, 189-204.

-and ILIFFE, T. M. 1986. Podocopid Ostracoda of Bermuda caves. Stygologia, 2, 26-76.

MARTINSSON, A. 1956. Neue Funde kambrischer G€ange und ordovizischer Geschiebe im sudwestlichen Finnland.€ Bulletin of the Geological Institutions of the University of Uppsala, 36, 79-105.

McCOY, F. 1844. A synopsis of the characters of the Carboniferous limestone fossils of Ireland. Dublin University Press, Dublin, viii +207 pp.

METCALFE, I. 2002. Permian tectonic framework and palaeogeography of SE Asia. Journal of Asian Earth Sciences, 20, 551-566.

-2011. Palaeozoic-Mesozoic history of SE Asia. 7-35. In HALL, R., COTTAM, M. A. and WILSON, M. E. J.

(eds). The SE Asian gateway: history and tectonics of Australia- Asia collision. Geological Society, London, Special Publications, 355,384 pp. 
METTE, W. 2008. Upper Permian and lowermost Triassic stratigraphy, facies and ostracods in NW Iran - implications for the P/T extinction event. Stratigraphy, 5, 205-219.

-2010. Ostracods from the Upper Permian and Permian/

Triassic boundary interval in Northwest Iran. Revista Espanola de Micropaleontologia, 42, 11-35.

MONTANEZ, I., TABOR, N., NIEMEIER, D., DIMIC- HELE, W., FRANK, T., FIELDING, C., ISBELL, J., BIRGENHEIER, L. and RYGEL, M. 2007. $\mathrm{CO}_{2}$-forced climate and vegetation instability during late Paleozoic deglaciation. Science, 315, 87-91. doi:10.1126/science.1134207

MOORE, R. C. 1961. Treatise on invertebrate paleontology, Part Q, Arthropoda 3, Crustacea, Ostracoda. Geological Society of America, Boulder, CO \& University of Kansas Press, Lawrence, KS, 442 pp.

MULLER, G. W. 1894. Die Ostracoden des Golfes von Neapel€ und der angrenzenden Meeres Abschnilte. Fauna und Flora Neapel, $21,1-404$.

MUTTER, R. J. and NEUMAN, A. G. 2009. Recovery from the end-Permian extinction event: evidence from "Lilliput Listracanthus". Palaeogeography, Palaeoclimatology, Palaeoecology, 284, 22-28. doi:10.1016/j.palaeo.2009.08.024

OERTLI, H. J. 1971. The aspect of Ostracode fauna - a possible new tool in petroleum sedimentology. 137-151. In OERTLI, H. J. (eds). Paleoecologie des Ostracodes. Bulletin du Centre de Recherche, SNPA 5 (Suppl.), 953 pp.

OLEMPSKA, E. 2001. Palaeozoic roots of the sigilliid ostracods. Marine Micropaleontology, 41, 109-123.

OZAWA, H. 2013. The history of sexual dimorphism in Ostracoda (Arthropoda, Crustacea) since the Palaeozoic. 51-80. In MORIYAMA, H. (eds). Sexual dimorphism. InTech Open Access Company, Rijeka, 149 pp.

PAYNE, J. L. 2005. Evolutionary dynamics of gastropods size across the end-Permian extinction and through the Triassic recovery interval. Paleobiology, 31, 269-290.

-and CLAPHAM, M. E. 2012. End-Permian mass extinction in the aceans: an ancient analog for the twenty-first century? Annual Review of Earth \& Planetary Sciences, 40, 89-111.

PENG, Y., SHI, G. R., GAO, Y., HE, W. and SHEN, S. 2007. How and why did the Lingulidae (Brachiopoda) not only survive the end-Permian mass-extinction but also thrive in its aftermath? Palaeogeography, Palaeoclimatology, Palaeoecology, 252, 118-131.

PERRIER, V., VANNIER, J. and SIVETER, D. J. 2007.

The Silurian pelagic myodocope ostracods Richteria migrans. Earth \& Environmental Science Transactions of the Royal Society of Edinburgh, 98 , $151-163$.

POLENOVA, E. N. 1952. Ostracods from the Upper Givetian of the Russian platform. VNIGRI (All Russia Petroleum

Research Exploration Institut), 60, 65-156. [in Russian]

-1955. Ostrakody Devona Voigo-Ural'skoi oblasti [Ostracods from the Devonian of the Volga-Ural region]. 191-287. In BYKOVA, E. Y. and POLENOVA, E. N. (eds). Foraminifery, radiolyarii i ostrakody devona volgo-ural'skoi oblasti [Foraminiferids, radiolarians and ostracods from the Devonian of the Volgo-Ural region]. Trudy Vsesoyuznogo Neftyanogo Nauchno-Issledovatel'skogo Geologo-Razvedochnogo Instituta (VNIGRI), Leningrad, novaya seriya 87, $152 \mathrm{pp}$.

PORTNER,€ H. O., PECK, L. S., ZIELINSKI, S. and

CONWAY, L. Z. 1999. Intracellular pH and energy metabolism in the highly stenothermal Antarctic bivalve Limopsis marionensisas a function of ambient temperature. Polar Biology, 22, 17-30.

POSNER, V. M. 1951. Ostrakody Nizhnego Karbona Zapadnogo Kryla Podmoskovnoi Kotloviny [Lower Carboniferous ostracods from the west flank of the Moscow Basin]. Trudy Vsesoyuznogo Neftyanogo Nauchno-Issledovatel'skogo GeologoRazvedochnogo Instituta (VNIGRI), Moskva Novaya Seriya, 56, 5-108. [in Russian]

REILLY, S. M., WILEY, E. O. and MEINHARDT, D. J.

1997. An integrative approach to heterochrony: the distinction between interspecific and intraspecific phenomena. Biological Journal of the Linnean Society, 60, 119-143.

ROHR, W. M. 1979. Nachweise von pr€aadulten Sexualdimorphismus bei den Podocopa (Ostracoda) und Grossen Variabi-€ lit€at brackischer Ostracoden. Neues Jahrbuch fur Geologie und€ Pal€aontologie Abhandlungen, 158, 346-380.

ROSSI, V., TONDELLI, B., GANDOLFI, A., BELLAVERE, C., MCKENZIE, K. G. and MENOZZI, P. 2003.

Heterocypris (Crustacea: Ostracoda) from the Isole Pelagie (Sicily, Italy): population genetics. Italian Journal of Zoology, 70, $101-108$.

-MARTORELLA, A. and MENOZZI, P. 2013. Hatching phenology and voltinism of Heterocypris barbara (Crustacea: Ostracoda) from Lampedusa (Sicily, Italy). Journal of Limnology, 72, 227-237.

ROTH, R. and SKINNER, J. 1930. The fauna of the McCoy

Formation, Pennsylvanian of Colorado. Journal of Paleontology, 4, 332-352.

RUTTNER, A. W. 1993. Southern borderland of Triassic Laurasia in north-east Iran. Geologische Rundschau, 82, $462-474$.

SARS, G. O. 1866. Oversigt af marine Ostracoder. Norske Videnskaps-Akademi, F€orhandlingar, 1865, 1-130.

- 1887. Nye bidrag til kundskaben om middelhavets invertebrafauna: 4. Ostracods mediterranea (sydeuropaeiske ostracoder). Archiv for Mathematik og Naturvidenskab, 12, 173-324.

-1910. Zoological results of the third Tanganyika Expedition, conducted by Dr W.A. Cunnington, 1904-1905. Report on the Ostracoda. Proceedings of the Zoological Society of London, 54, 732-760. 
- 1922-1928. An account of the Crustacea of Norway.

Volume 9, Crustacea. Bergen Museum, 9, 1-277.

SATO, T. and KAMIYA, T. 2007. Taxonomy and geographical distribution of recent Xestoleberis species (Cytheroidea, Ostracoda, Crustacea) from Japan. Paleontological Research, 11, 183-227.

SCHOBBEN, M., JOACHIMSKI, M. M., KORN, D.,

LEDA, L. and KORTE, C. 2014. Palaeotethys seawater temperature rise and an intensified hydrological cycle following the end-Permian mass extinction. Gondwana Research, 26, 675-683.

SCHWARTZMANN, C., DURRIEU, G., SOW, M., CIRET, P., LAZARETH, C. E. and MASSABUAU, J. C.

2011. In situ giant clam growth rate behavior in relation to temperature: a one-year coupled study of high-frequency noninvasive valvometry and sclerochronology. Limnology \& Oceanography, 56, 1940-1951.

SCOTT, H. W. 1959. The type species of Paraparchites Ulrich \& Bassler. Journal of Paleontology, 33, 670-674.

-1961. Suborder Beyrichicopina Scott n. suborder. Suborder

Kloedenellocopina Scott n. suborder. Q111-Q180. In MOORE, R. C. (ed.). Treatise on invertebrate paleontology, Part Q, Arthropoda 3.

Geological Society of America, Boulder, CO \& University of Kansas Press, Lawrence, KS, 442 pp.

SENGOR, A. M. C. 1979. Mid-Mesozoic closure of Permo-Tri-€ assic Tethys and its complications. Nature, 279, 590-593.

-1990. A new model for the late Palaeozoic - Mesozoic tectonic evolution of Iran and implication for Oman. 797-831. In ROBERTSON, A.

H. F., SEARLE, M. P. and RIES, C.

(eds). The geology and tectonics of the Oman Region. Geological Society, London, Special Publications, 49, 845 pp.

SEPKOSKI, J. J. JR 1984. A kinetic model of Phanerozoic taxonomic diversity. III. Post-Paleozoic families and mass extinctions.

Paleobiology, 10, 246-267.

SHARLAND, P. R., ARCHER, R., CASEY, D. M., DAVIES, R. B., HALL, S. H., HEWARD, A. P., HORBURY, A. D. and SIMMONS, M. D. 2001. Arabian plate sequence stratigraphy. GeoArabia Special Publication, 2, 1-371.

---SIMMONS, M. D. and SUTCLIFFE,

O. E. 2004. Arabian plate sequence stratigraphy - revisions to SP2. GeoArabia, 9, 199-214.

SHAVER, R. H. 1961. Family Bairdiocyprididae Shaver, n. fam. Q364. In MOORE, R. C. (ed.). Treatise on invertebrate paleontology, Part Q, Arthropoda 3. Geological Society of America, Boulder, CO \& University of Kansas Press, Lawrence, KS, 442 pp.

SHEN, S. Z. and SHI, G. R. 2009. Latest Guadalupian brachiopods from the Guadalupian/Lopingian boundary GSSP section at Penglaitan in Laibin, Guangxi, South China and implications for the timing of the pre-Lopingian crisis. Palaeoworld, 18, $152-161$.

SHI, C. G. and CHEN, D. Q. 1987. The Changhsingian ostracodes from Meishan Changxing, Zhejiang. Stratigraphy and Palaeontology of Systemic Boundaries in China; Permian \& Triassic Boundary, 5, 23-80. [in Chinese with English abstract]

--2002. Late Permian ostracodes from Heshan and Yishan of Guangxi. Bulletin of the Nanjing Institute Geology \& Paleontology, 15, 47-129. [in Chinese with English abstract]

SIVETER, D. J., SIVETER, D. J., SUTTON, M. D. and BRIGGS, D. E. G. 2007. Brood care in a Silurian ostracod. Proceedings of the Royal Society B, 274, 465-469.

SMITH, R. J. and HIRUTA, S. 2004. A new species of Metacypris (Limnocytherinae, Cytheroidea, Ostracoda, Crustacea) from Hokkaido, Japan. Species Diversity, 9, 37-46.

-and KAMIYA, T. 2001. The first record of an entocytherid ostracod from Japan. Benthic Research, 56, 57-61.

--2005. The ontogeny of the entocytherid ostracod Uncinocythere occidentalis (Kozloff and Whitman, 1954) Hart, 1962 (Crustacea). Hydrobiologia, 538, 217-229.

SOHN, I. G. 1971. New Late Mississippian Ostracode genera and species from Northern Alaska. A review of the Paraparchitacea. US Geological Survey Professional Paper, 711A, 1-24.

SONG, H. J., TONG, J., CHEN, Z. Q., YANG, H. and

WANG, Y. B. 2011. End-Permian mass extinction of foraminifers in the Nanpanjiang Basin, South China. Journal of Paleontology, 83, 718-738. STAMPFLI, G. and BOREL, G. D. 2002. A plate tectonic model for the Palaeozoic and Mesozoic constrained by dynamic plate boundaries and restored synthetic oceanic isochrones. Earth \& Planetary Science Letters, 196, 17-33.

SUN, Y., JOACHIMSKI, M. M., WIGNALL, P. B., YAN, C., CHEN, Y., JIANG, H., WANG, L. and LAI, X. 2011.

Lethally hot temperatures during the Early Triassic greenhouse. Science, 338, 366-370.

SYLVESTER-BRADLEY, P. C. 1961. Suborder Metacopina SylverterBradley, n. suborder. Q358-Q359. In MOORE, R. C. (ed.). Treatise on invertebrate paleontology, Part Q, Arthropoda 3, Crustacea, Ostracoda. Geological Society of America, Boulder CO \& University of Kansas Press, Lawrence, KS, 442 pp.

TANAKA, G. and IKEYA, N. 2002. Migration and speciation of the Loxoconcha japonica species group (Ostracoda) in East Asia. Paleontological Research, 6, 265-284.

TEISSIER, G. 1960. Reticulate growth. 541-544. In WATERMAN, T. H. (eds). The physiology of Crustacea, Volume 1: metabolism and growth. Academic Press, New York, 670 pp.

TSUKAGOSHI, $\quad$ A. 1998. On Callistocythere pumila Hanai. 
Stero-Atlas of Ostraocd Shells, 25, 9-16.

TWITCHETT, R. J. 2001. Incompleteness of the Permian-Triassic fossil record: a consequence of productivity decline? Geological Journal, 36, $341-353$.

-2005. The Lilliput Effect in the aftermath of the end-Permian extinction event. Albertiana, 33, 79-81.

-and OJI, T. 2005. Early Triassic recovery of echinoderms. Comptes Rendus Palevol, 4, 463-474.

ULRICH, E. O. and BASSLER, R. S. 1906. New American Palaeozoic Ostracoda. Notes and descriptions of the Upper Carboniferous genera and species. US National Museum Paper, 30, 149-164.

URBANEK, A. 1993. Biotic crises in the history of Upper Silurian graptoloids: a palaeobiological model. Historical Biology, 7, $29-50$.

VAN HARTEN, R. D. 1983. Resource competition as a possible cause of sex ratio in benthic Ostracodes. 568-581. In MADDOCKS, R. F. (ed.). Applications of Ostracoda. Proceedings of the eighth International Symposium on Ostracoda, held on the University of Houston central campus. Department of Geosciences, University of Houston, Houston, TX, 677 pp.

VAN MORKHOVEN, F. P. C. M. 1962. Post-Paleozoic Ostracoda, Vol 1. Elsevier, Amsterdam, 204 pp.

VERSLYCKE, T. and JANSSEN, C. R. 2002. Effects of a changing abiotic environment on the energy metabolism in the estuarine mysid shrimp Neomysis integer (Crustacea: Mysidacea). Journal of Experimental Marine Biology \& Ecology, 279, 61-72.

WABETE, N., CHIM, L., LEMAIRE, P. and MASSA-

BUAU, J. C. 2008. Life on the edge: physiological problems in penaeid prawns Litopenaeus stylirostris, living on the low side of their thermopreferendum. Marine Biology, 154, 403-412.

WANG, S. Q. 1978. Late Permian and Early Triassic ostracods of Western Guizhou and Northeastern Yunnan. Acta Palaeontologica Sinica, 17, 277-308. [in Chinese with English abstract]

WHATLEY, R. C. and STEPHENS, M. 1977. Precocious sexual dimorphism in fossil and recent Ostracoda. 69-91. In LOFFLER, H. and DANIELOPOL, D. (eds).€ Aspects of ecology and zoogeography of Recent and fossil Ostracoda. Junk, The Hague, 521 pp.

WHITELEY, N. M. 2011. Physiological and ecological responses of crustaceans to ocean acidification. Marine Ecology Progress Series, 430, 257271.

WIGNALL, P. B., SUN, Y. D., BOND, D. P. G., IZON, G., NEWTON, R. J., VEDRINE, S., WIDDOWSON, M., ALI, J. R., LAI, X. L., JIANG, H. S., COPE, H. and BOTTRELL, S. H. 2009. Volcanism, mass extinction, and carbon isotope fluctuations in the Middle Permian of China. Science, 324, 1179-1182.

WINDER, M. and SCHINDLER, D. E. 2004. Climatic effects on the phenology of lake processes. Global Change Biology, 10, $1844-1856$.

YAMAGUCHI, T., NORRIS, R. D. and BORNEMANN,

A. 2012. Dwarfing of ostracodes during the Paleocene-Eocene Thermal Maximum at DSDP Site 401 (Bay of Biscay, North Atlantic) and its implication for changes in organic carbon cycle in deep-sea benthic ecosystem. Palaeogeography, Palaeoclimatology, Palaeoecology, 346-347, 130-144. doi:10.1016/ j.palaeo.2012.06.004

YANG, Z. Y., WU, S. B., YIN, H. F., XU, G. R., ZHANG, K. X. and BI, X. M. 1993. Permo-Triassic events of South China. Geological Publishing House, Beijing, 153 pp.

YI, W. 2004. Ostracodes from the Upper Permian and Lower Triassic at the Kongtongshan section of Datian, Fujian. Acta Palaeontologica Sinica, 43, 556-570. [in Chinese with English abstract]

YIN, H., ZHANG, K., TONG, J., YANG, Z. and WU, S.

2001. The Global Stratotype Section and Point (GSSP) of the Permian-Triassic Boundary. Episodes, 24, 102-114.

YUAN, A., CRASQUIN, S., FENG, Q. and GU, S. 2009. Ostracods from Uppermost Permian siliceous and muddy rocks of Guizhou, Guangxi and Anhui. Acta Micropalaeontologica Sinica, 26, 385-403.

ZALANYI, B. 1974. Die Oberpermischen Ostrakoden des

Bukk-Gebirges. 95€-251. In SIDO, M., ZALANYI, B. and SCHRETER, M. (eds). Neue pal€aontologische Ergebnisse aus dem Oberpal€aozoikum des Bukk-Gebirges€. Akademiai Kiado, Budapest.

ZANCHI, A., ZANCHETTA, S., BERRA, F., MATTEI, M., GARZANTI, E., MOLYNEUX, S., NAWAB, A. and

SABOURI, J. 2009. The Eo-Cimmerian (Late? Triassic) orogeny in North Iran. 31-56. In BRUNET, M. F., WILMSEN, M. and GRANATH, J. W. (eds). South Caspian to Central Iran Basins. Geological Society, London, Special Publications, 312, 352 pp.

ZHOU, M. F., MALPAS, J., SONG, X. Y., ROBINSON, P. T., SUN, M., KENNEDY, A. K., LESHER, C. M. and KEAYS, R. R. 2002. A temporal link between the Emeishan large igneous province (SW China) and the end-Guadalupian mass extinction. Earth \& Planetary Science Letters, 196, 113-122. 